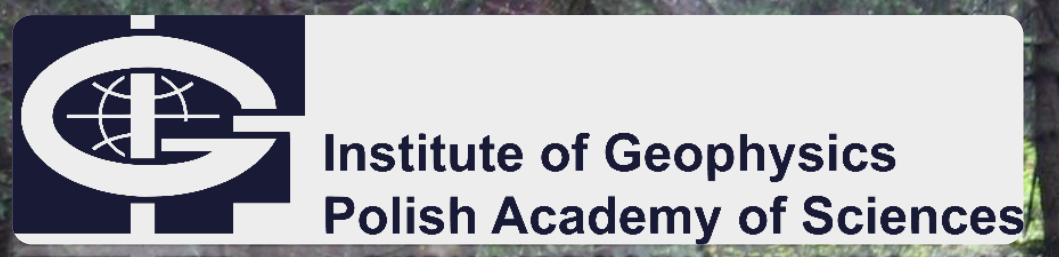

Polish Academy of Sciences

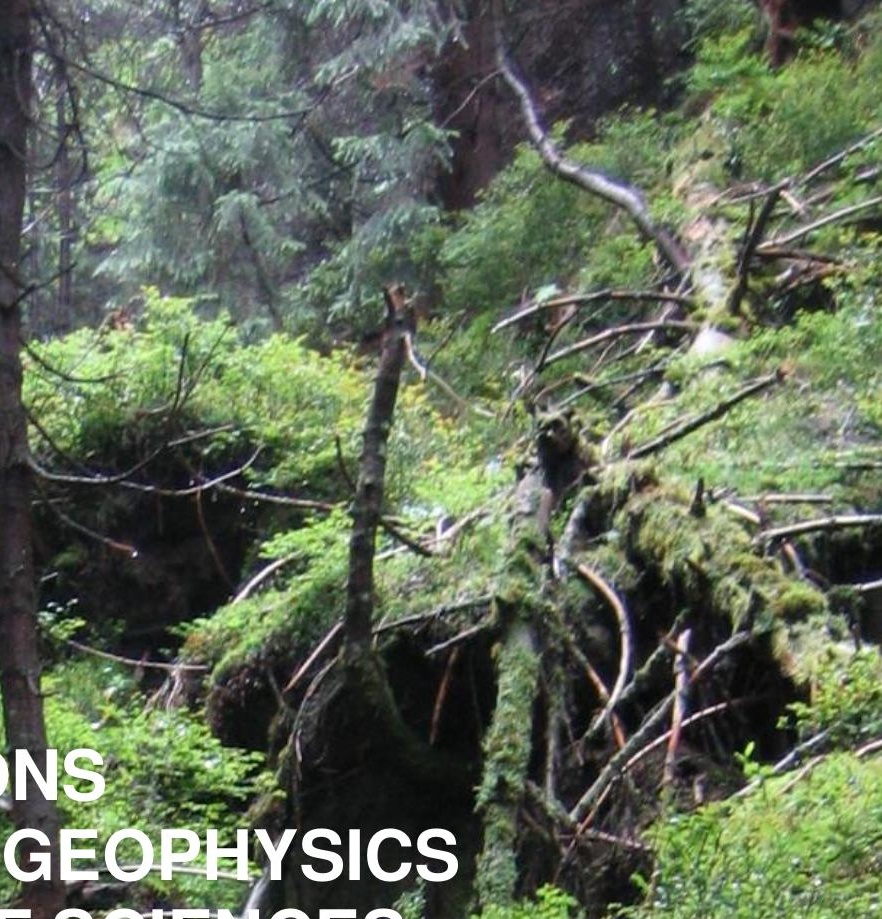
POULA ACADEMIY OF SMIE CES

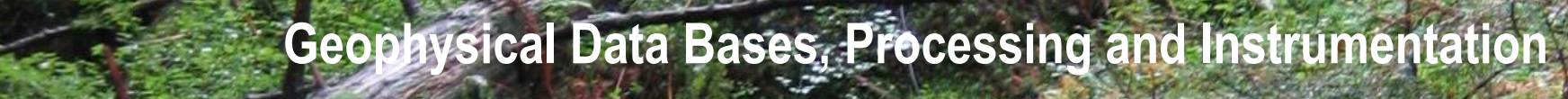
$425(M-32)$
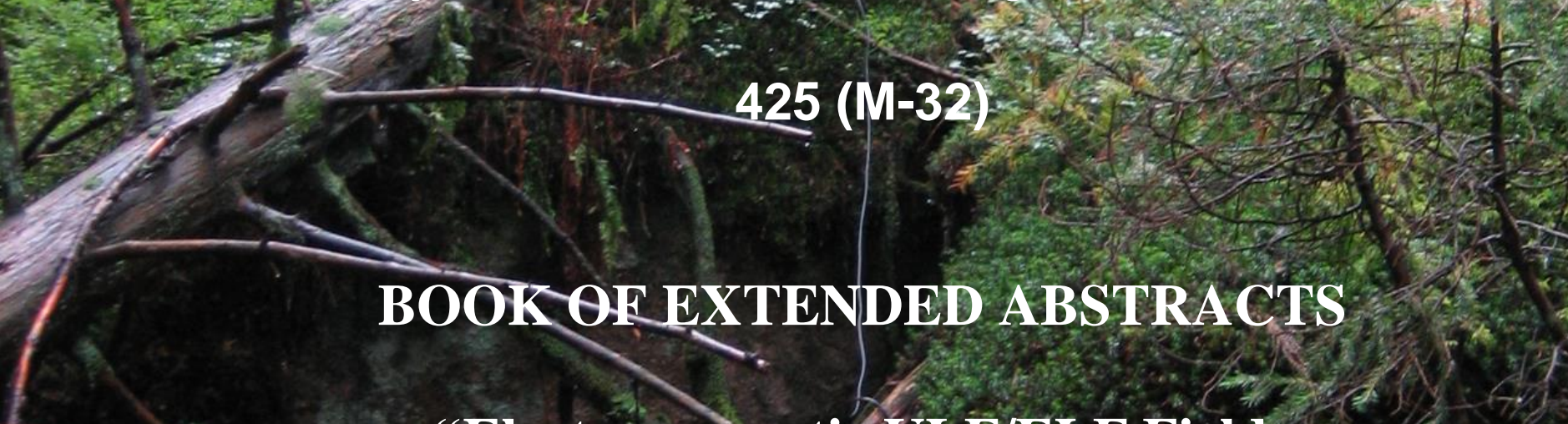

"Electromagnetic ULF/ELF Fields on Farth and in Space"

Conference, Warsaw, Poland 3.5 July 2019

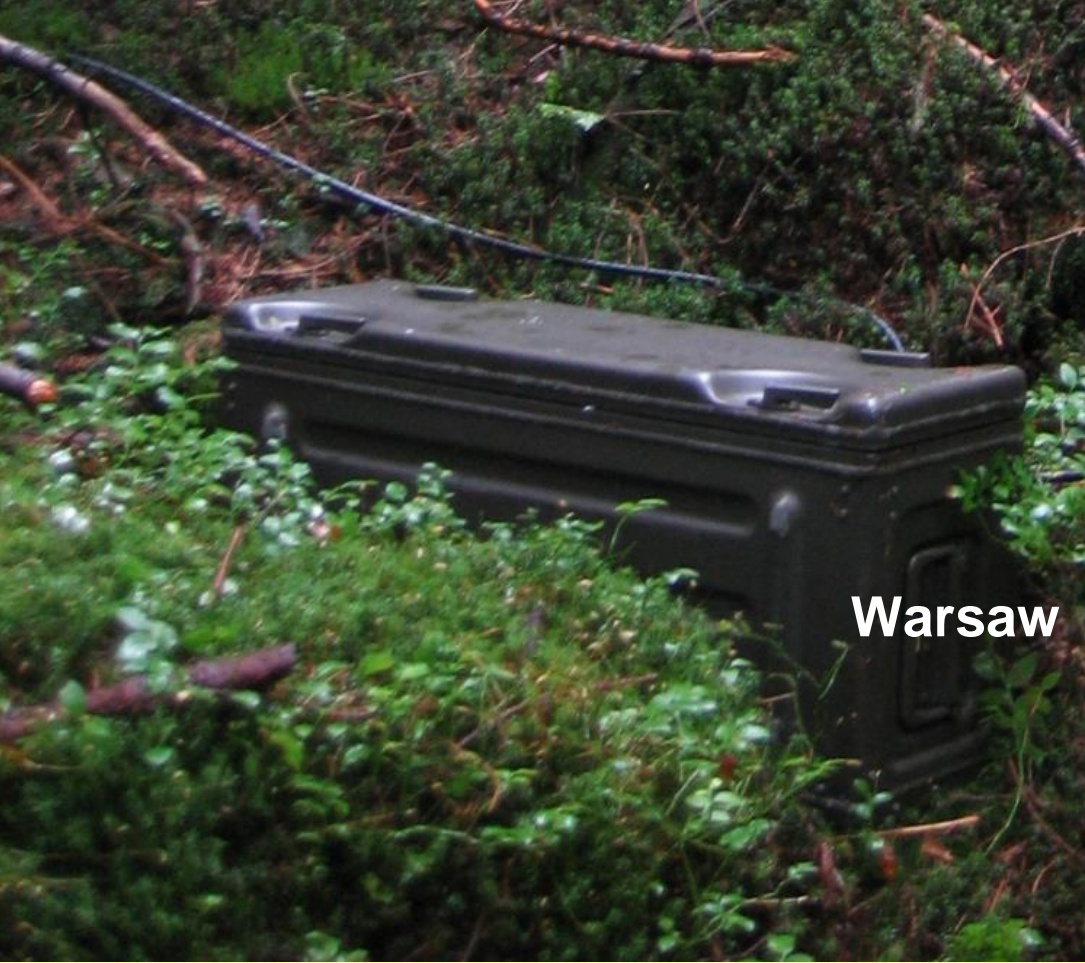




\section{INSTITUTE OF GEOPHYSICS \\ POLISH ACADEMY OF SCIENCES}

\section{PUBLICATIONS \\ OF THE INSTITUTE OF GEOPHYSICS \\ POLISH ACADEMY OF SCIENCES}

Geophysical Data Bases, Processing and Instrumentation

$$
425 \text { (M-32) }
$$

\section{BOOK OF EXTENDED ABSTRACTS}

"Electromagnetic ULF/ELF Fields

on Earth and in Space"

Conference, Warsaw, Poland

$$
\text { 3-5 July } 2019
$$

Editors: Andrzej Kułak, Anna Odzimek 
Honorary Editor

Roman TEISSEYRE

\section{Editor-in-Chief}

Marek KUBICKI

\section{Advisory Editorial Board}

Janusz BORKOWSKI (Institute of Geophysics, PAS)

Tomasz ERNST (Institute of Geophysics, PAS)

Jerzy JANKOWSKI (Institute of Geophysics, PAS)

Maria JELEŃSKA (Institute of Geophysics, PAS)

Andrzej KIJKO (University of Pretoria, Pretoria, South Africa)

Natalia KLEIMENOVA (Institute of Physics of the Earth, Russian Academy of Sciences, Moscow, Russia)

Zbigniew KŁOS (Space Research Center, Polish Academy of Sciences, Warsaw, Poland)

Jan KOZAK (Geophysical Institute, Prague, Czech Republic)

Antonio MELONI (Instituto Nazionale di Geofisica, Rome, Italy)

Hiroyuki NAGAHAMA (Tohoku University, Sendai, Japan)

Kaja PIETSCH (AGH University of Science and Technology, Cracow, Poland)

Paweł M. ROWIŃSKI (Institute of Geophysics, PAS)

Steve WALLIS (Heriot Watt University, Edinburgh, United Kingdom)

Wacław M. ZUBEREK (University of Silesia, Sosnowiec, Poland)

\section{Associate Editors}

Łukasz RUDZIŃSKI (Institute of Geophysics, PAS) - Solid Earth Sciences

Jan WISZNIOWSKI (Institute of Geophysics, PAS) - Seismology

Jan REDA (Institute of Geophysics, PAS) - Geomagnetism

Krzysztof MARKOWICZ (Institute of Geophysics, Warsaw University) - Atmospheric Sciences

Marek GOŁKOWSKI (University of Colorado Denver) - lonosphere and Magnetosphere

Andrzej KUŁAK (AGH University of Science and Technology) - Atmospheric Electricity

Marzena OSUCH (Institute of Geophysics, PAS) - Hydrology

Adam NAWROT (Institute of Geophysics, PAS) - Polar Sciences

\section{Managing Editors}

Anna DZIEMBOWSKA, Zbigniew WIŚNIEWSKI

Technical Editor

Marzena CZARNECKA

(C) Copyright by the Institute of Geophysics, Polish Academy of Sciences, Warsaw, 2019 ISBN 978-83-949850-7-3 ISSN-2544-428x elSSN-2299-8020

DOI: 10.25171/InstGeoph_PAS_Publs-2019-002

Photo on the front cover by Jerzy Kubisz 


\section{"Electromagnetic ULF/ELF Fields on Earth and in Space" Conference, Warsaw, Poland, 2019}

\section{PREFACE}

Tegoroczne spotkanie jest nową konferencją z cyklu „Pola ULF/ELF na Ziemi i w Przestrzeni Kosmicznej”, które odbywały się w bieszczadzkim Dwerniczku pod nazwą „Spotkania Bieszczadzkie”. „Spotkania”, organizowane od lat z inicjatywy krakowskiej Pracowni Pól ELF, odbyły się 15-krotnie w Dwerniczku i Zatwarnicy w Bieszczadach (1996-2013), raz wyjątkowo w Skawicy w Beskidzie Żywieckim (1997). „Spotkania” odbyły się ponadto w Niepołomicach (2013), Solcu-Zdroju (2014), Jaroszowcu (2015) i ponownie w Solcu-Zdroju (2015). W tym roku, po kilku latach przerwy, mamy przyjemność uczestniczyć w XXI „Spotkaniu”, tym razem odbywającym się w Instytucie Geofizyki PAN w Warszawie.

Wspólnym tematem konferencji są zagadnienia związane z fizyką i geofizyką układów naturalnych generujących pola o częstotliwościach leżących w zakresie ULF (Ultra Low Frequency -0.003 to $3 \mathrm{~Hz}$ ) oraz zakresie ELF (Extremely Low Frequency -3 do $3000 \mathrm{~Hz}$ ). W zakresie poniżej $3 \mathrm{~Hz}$ stosowano typowy podział geofizyczny zjawisk oscylacyjnych leżących w zakresach Pc1-Pc6. Obecnie po wprowadzeniu przez Międzynarodowy Związek Telekomunikacyjny (International Telecommunication Union - ITU) nowego podziału pasm, nastąpił chaos, ponieważ dawny zakres ELF został podzielony na 3 zakresy, w tym jednym z nich jest nowy zakres ULF. Stosowany obecnie podział przewiduje zakresy: ELF (Extremely Low Frequency -3 do $30 \mathrm{~Hz}$ ), SLF (Super Low Frequency - 30 do $300 \mathrm{~Hz}$ ) oraz ULF (Ultra Low Frequency -300 do $3000 \mathrm{~Hz}$ ).

Szczególna rola Bieszczad jako miejsca spotkań „ELF” ma swoje głębokie przyczyny. Bieszczady „wybrało” w 1991 r. poszukiwanie w Polsce właściwego miejsca do prowadzenia obserwacji naturalnych pól ekstremalnie niskiej częstotliwości. Wybór Bieszczad z perspektywy wielu lat okazał się wyjątkowo trafny. Dziś, po szeregu ekspedycji obserwacyjnych do Kanady, Ameryki Północnej i Ameryki Południowej oraz poszukiwaniach optymalnych miejsc do posadowienia stacji ELF w Europie, wiemy, że jest to miejsce unikalne pod względem niezwykle niskiego poziomu elektromagnetycznych zakłóceń cywilizacyjnych.

$\mathrm{Na}$ „Spotkaniach” poruszano liczne tematy związane z fizyką jonosfery, modelowaniem falowodu grunt-jonosfera, modelowaniem generacji fal w falowodzie przez wyładowania atmosferyczne, modelowaniem wnęki sferycznej, poszukiwaniem analitycznych i numerycznych rozwiązań równań pola we wnęce uwzględniających promieniowanie źródeł, modelowaniem rezonansu Schumanna we wnęce Ziemia-jonosfera, modelowaniem rezonansu fal Alfvéna w jonosferze, badaniem sprzężeń jonosfera-magnetosfera, modelowaniem globalnego obwodu elektrycznego, modelowaniem magnetosferycznego masera cyklotronowego oraz modelowaniem zorzowego kilometrowego promieniowania Ziemi. 
Szereg referatów poświęcono konstruowanej aparaturze obserwacyjnej i poszukiwaniu nowych metod analizy obserwowanych sygnałów. Zajmowano się metodami analizy rezonansu Schumanna, metodą dekompozycji widm mocy, zastosowaniem metody dekompozycji do badania parametrów wnęki, badaniem wpływu pogody kosmicznej na stan wnęki, badaniu globalnej aktywności burzowej i mapowaniu rozmieszczenia centrów burzowych. Omawiano zastosowania cyfrowej techniki nadawania Digital Radio Mondiale stosowanej w zakresie fal krótkich (HF - High Frequency) jako nowej możliwości globalnego monitoringu jonosfery. W miarę upływu lat w coraz większym stopniu dominowała tematyka związana z badaniami impulsów pola ELF obserwowanych we wnęce. Analizowano formy falowe impulsów generowanych przez wyładowania atmosferyczne różnych typów, nowe rozwiązania odwrotne służące do wyznaczania momentów prądowych i dipolowych źródeł, zagadnienia propagacji dalekozasięgowej, uwzględniającej wpływ terminatora i realistyczne modele przewodnictwa jonosfery. Demonstrowano zastosowania nowo opracowanej metody odwrotnego kanału do badania przebiegów momentów prądowych źródeł rozciągłych w czasie: wielkiego dżeta europejskiego z 2009 roku oraz sprajtów. Analizowano koincydencję impulsów pola ELF rejestrowanych na stacji Hylaty z ziemskimi atmosferycznymi błyskami gamma (Terrestrial Gammaray Flash - TGF) obserwowanymi przez orbitalne obserwatorium Comptona (Compton Gamma Ray Observatory). Analizowano zagadnienia oceny dokładności wyznaczania pozycji i parametrów źródeł przy pomocy budowanego globalnego systemu radiolokacyjnego WERA.

$\mathrm{Na}$ „Spotkaniach” pojawiały się również tematy związane z oddziaływaniem pól elektromagnetycznych ELF i fal infradźwiękowych na organizmy żywe. Analizowano modele oddziaływania pól na mózg ludzki, na pracę węzła zatokowo-przedsionkowego serca oraz dyskutowano wyniki badań laboratoryjnych prowadzonych w tym zakresie.

W „Spotkaniach Bieszczadzkich” począwszy od 1996 r. uczestniczyli przedstawiciele Akademii Górniczo-Hutniczej w Krakowie, Uniwersytetu Jagiellońskiego, Akademii Rolniczej w Krakowie, Politechniki Rzeszowskiej, Centrum Astronomicznego im. Mikołaja Kopernika Polskiej Akademii Nauk (PAN) w Warszawie i w Toruniu, Centrum Badań Kosmicznych PAN, Instytutu Geofizyki PAN, Interdyscyplinarnego Centrum Modelowania Matematycznego i Komputerowego Uniwersytetu Warszawskiego, Uniwersytetu Marii Curie-Skłodowskiej w Lublinie, Wyższej Szkoły Humanistyczno-Ekonomicznej we Włocławku i innych instytucji, a także sporadycznie zapraszani goście z zagranicy. Ogółem w ramach dotychczasowych konferencji wygłoszono ok. 250 wykładów, których wysłuchało w sumie ok. 300 uczestników. Szczególnie liczne grono przedstawicieli różnych środowisk geofizycznych w Polsce zgromadziło uroczyste otwarcie automatycznej stacji obserwacyjnej ELF Hylaty w czasie XI „Spotkań Bieszczadzkich” w 2006 r.

Wszyscy pamiętamy w jak niezwykle spontanicznej atmosferze przebiegały „Spotkania Bieszczadzkie” w Dwerniczku. Przyczyniało się do tego piękno miejsca, gościnność gospodarzy z Rusinowej Polany oraz świadomość uczestniczenia w prowadzeniu nowych, niezwykle ciekawych badań. Referaty dotyczyły najczęściej zagadnień zupełnie nowych, wyników uzyskanych w ciągu minionego roku. Chwilami mieliśmy poczucie odkrywania nowego świata i wrażenie stąpania po ścieżkach, po których jeszcze nikt nie chodził. Niezapomniane pozostaną wieczory dyskusyjne ,przy kawie i herbacie”, w scenerii rozgwieżdżonego nieba i atmosferze rodzącej się poezji o badaniach fal ELF.

Ten w części improwizowany charakter dawnych „Spotkań” miał też oczywiście słabe strony. Powstawały braki w dokumentacji, nie zachowały się programy szeregu spotkań, a materiały z wykładów, o ile były dostępne, ukazywały się tylko w formie elektronicznej. Pewnym pocieszeniem jest fakt, że na „Spotkaniach” omawiano tematy, które potem doprowadziły do powstania kilkudziesięciu publikacji w renomowanych czasopismach geofizycznych, obecnie dostępnych. 
Nasza „Konferencja Warszawska” to „Spotkania Bieszczadzkie” wchodzące w wiek dojrzały. $Z$ wyprzedzeniem udało się ustalić wystąpienia uczestników i wydrukować abstrakty wystąpień. Centralna lokalizacja konferencji sprzyja szerszemu uczestnictwu. Mamy nadzieję, że będzie kontynuacją świetnej historii i zapoczątkuje nowy periodyczny cykl spotkań, który przyczyni się do dalszego rozwoju tej ciągle młodej dziedziny badań.

This year's meeting is a new conference in the series "ULF/ELF Fields on Earth and in Space", which used to take place in the Bieszczady mountains in Poland under the name "Bieszczady Meetings". The "Meetings" organised for years on the initiative of the Krakow ELF Group took place 15 times in Dwerniczek and Zatwarnica in Bieszczady (1996-2012), once in Skawica in Beskid Żywiecki (1997), in Niepołomice (2011), Solec-Zdrój (2014), Jaroszowiec (2015) and again in Solec-Zdrój (2015). This year, after a few years break, we have the pleasure to participate in the XXI "Meeting", this time taking place at the Institute of Geophysics PAS in Warsaw.

A common topic of the conference are issues related to physics and geophysics of natural systems generating fields of frequencies in the ULF (Ultra Low Frequency - 0.003 to $3 \mathrm{~Hz}$ ) range and ELF (Extremely Low Frequency - 3 to $3000 \mathrm{~Hz}$ ) range. In the range below $3 \mathrm{~Hz}, \mathrm{a}$ typical geophysical division of the pulsation phenomena in the Pc1-Pc6 ranges was used. Currently, after the International Telecommunication Union (ITU) introduced a new division of frequency bands, there was chaos, because the former ELF range was divided into three ranges, and one of them is called a ULF range. The division currently used includes the following bands: ELF (Extremely Low Frequency - 3 to $30 \mathrm{~Hz}$ ), SLF (Super Low Frequency - 30 to 300 $\mathrm{Hz}$ ) and ULF (Ultra Low Frequency 300 to $3000 \mathrm{~Hz}$ ).

From 1996 the participants of the "Bieszczady Meetings" included representatives of the AGH University of Science and Technology in Krakow, Jagiellonian University, Rzeszow University of Technology, Agriculture University in Krakow, Nicolaus Copernicus Astronomical Centre of Polish Academy of Sciences (PAS) in Warsaw, Nicolaus Copernicus Astronomical Centre PAS in Torun, Space Research Centre PAS, Institute of Geophysics PAS, Maria CurieSkłodowska University in Lublin, Interdisciplinary Centre for Mathematical and Computational Modelling of Warsaw University, School of Humanities and Economics in Włoctawek, and others, as well as occasionally invited guests from abroad. In total, about 250 lectures were delivered at previous conferences and about 300 researchers participated. In particular, a large group of representatives of the geophysical and space research groups in Poland gathered at the grand opening of the ELF Hylaty automatic observation station during the 11th "Bieszczady Meeting" in 2006.

The "Meetings" dealt with numerous topics related to ionospheric physics, modelling of the ground-ionosphere waveguide, modelling of waveforms generated in the waveguide by lightning discharges, modelling of the spherical cavity, search for analytical and numerical solutions of the field equations in the cavity taking into account the source radiation, Schumann resonance modelling in the Earth-ionosphere cavity, modelling of the ionospheric Alfvén resonance, study of the ionosphere-magnetosphere coupling, modelling of the global electrical circuit (GEC), modelling of the magnetospheric cyclotron maser and modelling of the AKR Auroral Kilometric Radiation of the Earth.

A number of presentations regarded the construction of observation apparatus and the search for new methods of analysing the observed signals. Methods of Schumann resonance analysis, the method of decomposition of power spectra, application of the decomposition method to study the cavity parameters, studies of the influence of space weather on the cavity's condition, global lightning activity and mapping of the distribution of thunderstorm centres 
were considered. The application of the digital technique of broadcasting "Digital Radio Mondiale" using the short waves (HF - High Frequency) as a new possibility of global monitoring of the ionosphere was discussed. As the years went by, topics related to ELF field impulses observed in the cavity were more and more dominant. Waveforms of signals generated by atmospheric lightning discharges of various types were analysed, and new inverse solutions were used to determine the current and dipole moments of the sources, and issues of long-range propagation have been studied taking into account the effect of the terminator and realistic models of ionospheric conductivity. The applications of the newly developed reverse channel method for the study of current moment of sources extended in time were demonstrated for the European gigantic jet of 2009 and for sprites. The coincidence of the ELF field pulses recorded at the Hylaty station with terrestrial gamma-ray flashes (TGF) observed by Compton Gamma Ray Observatory was analysed. The issues of assessing the accuracy of determining the positions and parameters of sources using the constructed global WERA ELF receiver system were the latest topics.

The "Meetings" also included research topics related to the influence of ELF electromagnetic fields and infrasound waves on living organisms. The models of field effects on the human brain, on the operation of the sinus-atrial node of the heart were analysed and the results of laboratory tests conducted in this field were discussed.

Our "Warsaw Conference" is a "Bieszczady Meeting" entering into a mature age. It was possible to determine the participants' presentation titles in advance and to publish the abstracts. The central location of the conference in Warsaw encourages wider participation. We hope that it will be a continuation of a great story and will start a new series of ELF meetings that will contribute to the further development of this constantly young field of research.

Andrzej Kułak

Krakowska Grupa ELF

Z inicjatywy Oddziału Fizyki Wnętrza Ziemi i Przestrzeni Okołoziemskiej Polskiego Towarzystwa Geofizycznego z dużą przyjemnością gościmy kolejną konferencję „Pola Elektromagnetyczne ULF/ELF na Ziemi i w Przestrzeni Kosmicznej” w nowej lokalizacji w Instytucie Geofizyki Polskiej Akademii Nauk w Warszawie.

Wyrażam głęboką wdzięczność Dyrekcji Instytutu Geofizyki PAN, która zgodziła się, by Instytut podjął trud organizacji konferencji oraz publikacji wydawnictwa konferencyjnego. Dziękuję wszystkim Pracownikom Instytutu biorącym udział w tym przedsięwzięciu. Dziękuję Koleżankom i Kolegom z Oddziału Fizyki Wnętrza Ziemi i Przestrzeni Okołoziemskiej Polskiego Towarzystwa Geofizycznego, którzy wsparli tę konferencję poprzez czynny udział oraz pomoc naukową i organizacyjną.

Doniesienia konferencyjne podzieliliśmy tematycznie na cztery kategorie:

- Rezonans Schumanna i jego zastosowania

- Systemy pomiarowe, metody matematyczne i numeryczne oraz modelowanie

- Teledetekcja w pasmie ELF, LF i HF

- Układy burzowe, wyładowania atmosferyczne i promieniowanie $\mathrm{w}$ pasmie $\mathrm{ULF} / \mathrm{ELF} / \mathrm{LF}$ 
Wszystkie opublikowane prace były poddane weryfikacji naukowej, językowej i edytorskiej. Dziękuję członkom Komitetu Naukowego oraz pozostałym osobom zaangażowanym w proces oceny przesłanych doniesień. Dziękuję Redakcji Publications za przygotowanie ich do publikacji w ostatecznej formie.

Wyrażam nadzieję, że ta publikacja będzie ciekawym i inspirującym źródłem tematów badań geofizycznych na temat pól i fal elektromagnetycznych w pasmie ULF/ELF oraz LF i HF, szczególnie tych prowadzonych w kraju.

Szczegółowe informacje o konferencji można znaleźć na stronie http://bit.ly/ELFkonf2019.

With great pleasure, at the initiative of the Department of the Earth's Interior and NearSpace Physics at Polish Geophysical Society, we host the next conference "Electromagnetic Fields ULF/ELF on Earth and in Space" in the new location at the Institute of Geophysics, Polish Academy of Sciences in Warsaw.

I express my deep gratitude to the Directors of the Institute of Geophysics PAS who agreed that the Institute undertook the task of organising the conference and publication of conference abstracts. I thank all the Institute's Employees taking part in this undertaking. I would also like to thank all Colleagues from the Department of the Earth's Interior and Near-Space Physics of Polish Geophysical Society who supported this conference through active participation and scientific and organisational help.

We divided the conference abstracts into four categories:

- The Schumann Resonance and its applications

- Observational systems, mathematical and numerical methods, modelling

- ELF, LF and HF remote sensing

- Thunderstorms, lightning discharges and ULF/ELF/LF radiation

All the works were subjected to scientific, linguistic and editorial verification. I would like to thank the members of the Scientific Committee and other people involved in the evaluation process of the submitted abstracts. I would like to thank the Editorial Office for the preparation of abstracts for publication in their final form.

I hope that this publication will be an interesting and inspiring source of topics on geophysical research in the field of electromagnetic waves and fields in the ULF/ELF and LF and HF range, especially those conducted in Poland.

Detailed information about the conference can be found at http://bit.ly/ELFkonf2019.

Anna Odzimek

Instytut Geofizyki Polskiej Akademii Nauk

Polskie Towarzystwo Geofizyczne

Oddział Fizyki Wnętrza Ziemi i Przestrzeni Okołoziemskiej

All abstracts were accepted for publication on 12 June 2019. 



\title{
The Schumann Resonance and its applications
}

\author{
Rezonans Schumanna \\ i jego zastosowania
}





\title{
Modern Research on the Schumann Resonances
}

\author{
Andrzej KULAK ${ }^{1, \bowtie}$ \\ ${ }^{1}$ Department of Electronics AGH University of Science and Technology, Krakow, Poland \\ kulak@oa.uj.edu.pl
}

In 1952, W.O. Schumann unexpectedly published a series of works on the Earth-ionosphere cavity (Schumann 1952a, b, c). He opened a new field of geophysical research, focusing on the issues of ELF wave propagation in the Earth-ionosphere waveguide. The cavity considered by Schumann was idealised; it consisted of two concentric perfectly conductive spherical surfaces, spaced by the "height of the ionosphere" $h$. Schumann's solutions showed that the resonance frequencies of the cavity are practically independent of $h$ and are given by the equation $f_{n}=7.49(n(n+1))^{1 / 2}$, which gives the first modes: 10.6, 18.4, 26.0, 33.5, 41.1,.. Hz. The first attempt to observe resonances of atmospheric noise carried out in Munich failed (Schumann and König 1954).

Schumann's publications were soon noticed and generated a considerable interest. Most of the works in the initial period were of an academic nature, but the Pangloss research program launched in 1959 by the US Navy focused mainstream research within its framework. The main goal of the military program was an artificial generation of Schumann resonances, with the aim to build a global communication system (Wait 1972, 1977). Before the system for generation of artificial waves was developed, M. Balser and C.A. Wagner from MIT (Massachusetts Institute of Technology) carried out the first successful observation of natural Schumann resonance field (Balser and Wagner 1960). This confirmed the opinion that the noise generated by atmospheric discharges is sufficient for the Schumann resonance studies (Balser and Wagner 1962, Pierce 1963, Blackband 1964, Rycroft 1965, Polk 1969). A significant deviation of the observed resonance frequencies of the cavity: 8, 14, 20, 26, 32, ... Hz from those anticipated by Schumann required modelling of the cavity considering the influence of the ionosphere. Soon, the first models of ELF wave propagation in the ground-ionosphere waveguide were created. They were taking into account the dispersive nature of losses caused by a conductive ionosphere (Galejs 1961, Wait 1962). A simple exponentially increasing vertical profiles of ionospheric conductivity improved the accuracy of modelling of the cavity to such extent that the quality factors and resonance frequencies became close to those observed (Row 1962, Wait 1962, Jones 1964, Chapman and Jones 1964, Galejs 1965, Rycroft 1965). The use of more realistic aeronomical conductivity profiles of the ionosphere contributed to further improvement of the Earth-ionosphere cavity model (Madden and Thompson 1965, Jones 1967, Galejs 1970, Booker and Lefeuvre 1977, Tran and Polk 1979, Bliokh et al. 1980). 
The work of Madden and Thompson (1965) also opens a new stage of the modelling of the ground-ionosphere waveguide in the ELF range. Due to the low height of the ionosphere compared with the wavelength of ELF waves in the cavity, the authors proposed the adoption of the TDTE (Two-Dimensional Telegraph Equations) model in the form of the twodimensional spherical transmission line in which Maxwell 3D field equations are replaced with telegraph equations for voltages and currents. In the Madden and Thompson transmission line, the distance $h$ between the ground and the ionosphere is constant and does not depend on the frequency.

In the nineteen seventies, as part of the Sanguine project, the first propagation measurements were carried out on continental paths (Bernstein et al. 1974, Wait 1972, 1977). Broadband quasi-orthogonal grounded antennas having the lengths of several dozen kilometers were used in this research. As a result of measurements conducted in the $40-80 \mathrm{~Hz}$ range, the frequency $76 \mathrm{~Hz}$ was selected as an optimal operating frequency for the future global Seafarer system intended for communications with submarines, and the measured ground-ionosphere waveguide attenuation rate at this frequency was determined to be $1.2 \mathrm{~dB} / \mathrm{Mm}$ during the day and $0.8 \mathrm{~dB} / \mathrm{Mm}$ during the night (Bannister 1975, Burrows 1978).

At the end of the nineteen seventies, C. and P. Greifinger (Greifinger and Greifinger 1978, 1979) made a breakthrough in the ground-ionosphere waveguide modelling. Analyzing the mechanisms of penetration of the electric and magnetic field components of the EM waves into the ionosphere, they introduced two different characteristic heights of the waveguide: the electric height $h_{e}$ and the magnetic height $h_{m}$. They introduced simple relationships between the height ratio and the phase velocity and attenuation coefficient in the waveguide. This idea was used in Sentman's works on the two-height Earth-ionosphere cavity (Sentman 1990, 1996). Soon after, Kirillov (Kirillov 1993, Kirillov et al. 1997, Kirillov and Kopeykin 2002) noted that the characteristic heights described by the Greifingers $h_{e}$ and $h_{m}$ are closely related to the unit parameters $\mathrm{L}$ and $\mathrm{C}$ of the two-dimensional transmission line introduced by Madden and Thompson (1965). Over the next few years a number of publications focused on the modelling of characteristic heights $h_{e}$ and $h_{m}$ versus the frequency, using different ionospheric conductivity profiles. The characteristic heights became the basic parameters of the groundionosphere waveguide, allowing for solving any propagation problems and resonance phenomena in the ground-ionosphere cavity in the ELF range (Kirillov et al. 1997, Mushtak and Williams 2002, Williams et al. 2006, Pechony and Price 2004, Kulak and Mlynarczyk 2013, Kulak et al. 2013, Galuk et al. 2015).

Over the years, the number of Schumann resonance observatories was growing. The ELF waves in the ground-ionosphere waveguide are quasi-orthogonal (q-TEM), the polarization of the electrical component is vertical, and the two independent orthogonal magnetic components are horizontal, parallel to the ground. Therefore, the observation of the electrical component is carried out using short vertical dipoles, and the magnetic components are recorded with a pair of perpendicular magnetic loop antennas or ferrite antennas (Ogawa et al. 1966). Sometimes a full set of antennas is used to measure orthogonal components, which enables observations of Schumann resonances using the Poynting vector spectrum (Belyaev et al. 1999). Observational publications focus on measurements of Schumann resonance parameters, their variability and its causes (e.g. Balser and Wagner 1962, Ogawa et al. 1968, Polk and Toomey 1972, Nickolaenko and Rabinowicz 1995, Nickolaenko 1997, Nickolaenko et al. 1998, Sátori 1996, Neska and Sátori 2006, Greenberg and Price 2007). The amplitudes and frequencies of individual resonance modes are studied in function of time and spatial distribution of atmospheric discharges. In individual observatories there are significant daily fluctuations of resonance frequencies, reaching up to $0.5 \mathrm{~Hz}$ in the case of the first mode. The 
difference in the resonance amplitudes observed simultaneously on the day and night side of the cavity was noticed as well (Sentman and Fraser 1991).

The effect of the disturbance of the upper ionospheric layers on the state of the cavity, caused by rapid increase in the solar activity was analysed (Blackband 1964, Cannon and Rycroft 1982, Magunia 1996). Long-term changes in the cavity parameters were also analyzed over time intervals covering the 11-year cycle of solar activity (Kulak et al. 2003b, Sátori et al. 2005). The view was established that $\mathrm{UV}$ and $\mathrm{X}$ radiation reaching the ionospheric $\mathrm{D}$ layer and increasing its ionization, increases the modal resonant frequencies and the quality factor of the cavity. In turn, sporadic streams of high-energy protons reaching the ionospheric layer C (about $35 \mathrm{~km}$ ) have the opposite effect (Schlegel and Füllekrug 1999, Roldugin et al. 2001). The effects of various types of ionospheric disturbances on Schumann resonances were also considered theoretically (Galejs 1972, Sentman 1983, Füllekrug 2000, Füllekrug et al. 2002). A current review of the work concerning the impact of high-energy solar emissions on the Earth-ionosphere cavity can be found in Williams and Sátori (2007) and Sátori et al. (2016).

The discovery of strong influence of the temperature variations in the atmosphere of the tropical zone on the amplitude of the 1st Schumann resonance mode made by Williams (1992), opened new possibilities for accurate climate monitoring (Rycroft et al. 2000). Research on reconstruction of global storm activity based on Schumann resonance spectra was conducted before as well. Simplified analytical solutions based on the method of variable separation were used for this purpose, describing the resonance component of the field in the cavity (Galejs 1972). These frequency solutions are characteristic for the source-observer distance, which enabled using them as a source distance indicator. Inverse solutions rely on the search for the analytical spectrum that is closest to the observational spectrum and on this basis determining the distance of the observer from the storm center and determining its intensity (Clayton and Polk 1977, Polk and Toomey 1972, Heckman et al. 1998, Nickolaenko and Rabinowicz 1995, Nickolaenko et al. 1998, Shvets 2001, Yang et al. 2009).

Analysis of strict solutions for inhomogeneous field equations, which take into account the space-time mechanism of filling the cavity by a point source, reveals that there are significant deviations of the real distribution of fields in the cavity from a simplified solution obtained by separation of variables (Kulak et al. 2003a). These differences are caused by the waves propagating directly from the source, before they form a resonance field as a result of interference of waves propagating around the globe. Strict solutions have fully explained why significant changes in the observed Schumann resonance frequencies depend on the observer-source distance. For example, in the case of the first mode, observers located close to the source record spectra with lower Schumann resonance frequencies, much lower than the resonance frequencies of the cavity.

The application of full solutions to solving inverse problems opened a new stage in research on the distribution of sources and measurements of cavity parameters. Thanks to the accuracy of the new method, it was possible to measure the parameters of the cavity during an 11-year solar activity cycle and analytically link the resonance frequencies of the cavity with the Wolf sunspot number (Kulak et al. 2003b). The next stage of research on the ELF fields in the Earth-ionosphere cavity was the development of the Schumann resonance power spectrum decomposition method (Kulak et al. 2006). Thanks to this method, based on the idea of Fano resonance (Fano 1961), it is possible to decompose the power spectrum of the field in the cavity by separating the symmetrical part from other components of the spectrum. Because the symmetrical components of modal spectral maxima have a strict relationship with the resonant field component, the remaining components can be attributed to the waves propagating directly from the sources. The application of the decomposition method to study the spectra of inhomogeneous field equations showed that the frequencies of the maxima of resonant field 
component in the cavity (and their widths related to quality factor) are independent of the source-observer distance and are the only invariant parameters for all observers located in the cavity (Kulak et al. 2006). Thus, the use of the decomposition method for analyzing the observational power spectra of the Schumann resonances opened a new path for precise measurements of the Earth-ionosphere cavity parameters. The possibility of separating the resonance field component from the observed Schumann resonance spectrum also opened new possibilities in solving inverse problems and measurements of storm activity. Since the sum of the power of resonant modes is a measure of the current moment of instantaneous discharges in the cavity, it is possible to measure the global intensity of thunderstorms, without errors resulting from the addition of spectral components originating from direct waves.

The first application of the new method was a study of global storm intensity index, describing the daily activity patterns of three world storm centers (Nieckarz et al. 2009a). In another work it was shown that the selected time intervals of the storm intensity index closely correlates with the value of the field $E_{0 z}$ associated with the ionospheric potential (Nieckarz et al. 2009b). These results show that the decompositon method opens new opportunities for the quantification of contribution of thunderstorms to the global atmospheric electric circuit, in addition to the opportunities arising from the analysis of ELF radiation from lightning (Odzimek and Lester 2009). The application of the decomposition method has also contributed to a significant improvement in inverse solutions. The algorithm that was used to determine the distance consisted of searching for analytical spectra of the resonant field component most closely related to observational spectra, was based on an erroneous assumption that the observed Schumann resonance spectra describe the resonant field component. Thanks to the method of decomposition of observational spectra this inaccuracy can be avoided and the same categories of analytical and observational spectra can be compared.

The use of a single station, equipped with two orthogonal magnetic antennas, allows Schumann resonance to be recorded along any of great circles passing through the station (Kulak et al. 2014). For the first time using the spectral decomposition method, daily and seasonal studies of the location and intensity of the African storm center were carried out (Dyrda et al. 2014). This opened new possibilities for mapping global storm activity, especially when using multiple observation stations located on several continents. Another important application of the decomposition method is the continuous measurement of cavity parameters with a temporal distribution capacity of the order of minutes. This allows observing rapid changes in parameters caused by strong solar flares and tracking the $D$-layer disturbances caused by UV radiation, $\mathrm{X}$ rays and protons (Dyrda et al. 2015).

Current research focuses on more accurate modelling of the spherical Earth-ionosphere waveguide, taking into account the influence of solar terminator and ionospheric heterogeneities (Kudintseva et al. 2016, Nickolaenko et al. 2016). This enables improvement of inverse solutions for reconstructing the current moment of the sources observed using the global WERA system (Kułak and Młynarczyk 2011, Mlynarczyk et al. 2015, 2017a, b; Gołkowski et al. 2018). The global WERA system has played an important role in verifying the impact of ELF electromagnetic fields on the work of LIGO gravitational wave detectors (Coughlin et al. 2016).

After nearly 70 years since the first Schumann publications, the intensity of research related to ELF waves is not weakening and there is no indication that this will change in the near future. On the one hand, the Earth-ionosphere cavity turned out to be a large isotropic detector of the stream of particles penetrating the ionosphere, allowing to monitor the space weather. On the other hand, thanks to the long-range propagation of ELF waves, it enables global monitoring of strong atmospheric discharges of various types and storm centers, regardless of the position of the observer. Due to an advanced state of propagation modelling and inverse solutions, measurements of discharge parameters and storm center activity are carried out with 
high accuracy in absolute units. In the coming years, they will play an important role in tracking climate change on global scale (Williams et al. 2019). It should also be kept in mind that the research methodology developed for Earth can be easily used to the resonance cavities of planets and moons of the solar system (Kulak et al. 2013, Kozakiewicz et al. 2015). And that means further intensification of research.

Acknowledgments. This work was supported by the National Science Centre, Poland, under Grant 2015/19/B/ST9/01710.

\section{References}

Balser, M., and C.A. Wagner (1960), Observations of Earth-ionosphere cavity resonances, Nature 188, 638, DOI: $10.1038 / 188638 \mathrm{a} 0$.

Balser, M., and C.A. Wagner (1962), Diurnal power variations of the Earth-ionosphere cavity modes and their relationship to worldwide thunderstorm activity, J. Geophys. Res. 67, 2, 619-625, DOI: 10.1029/JZ067i002p00619.

Bannister, P.R. (1975), Project Sanguine Quarterly Technical Summary, 1 July - 20 September 1974, NUSC Technical Report, No. 4907.

Belyaev, G.G., A.Yu. Schekotov, A.V. Shvets, and A.P. Nickolaenko (1999), Schumann resonances observed using Poynting vector spectra, J. Atmos. Sol.-Terr. Phys. 61, 751-763.

Bernstein, S.L., M.L. Burrows, J.E. Evans, A.S. Griffiths, D.A. McNeil, C.W. Niessen, I. Richer, D.P. White, and D.K. Willim (1974), Long-range communications at extremely low frequencies, Proc. IEEE 62, 3, 292-312, DOI: 10.1109/PROC.1974.9426.

Blackband, W.T. (ed.) (1964), Propagation of Radio Waves at Frequencies Below 300 kcs, Pergamon Press, Oxford.

Bliokh, P.V., A.P. Nickolaenko, Yu.F. Filippov, and D.Ll. Jones (eds.), (1980), Schumann Resonances in the Earth-Ionosphere Cavity, Peter Peregrinus, London.

Booker, H.G., and F. Lefeuvre (1977), The relation between ionospheric profiles and ELF propagation in the Earth-ionosphere transmission line, J. Atmos. Terr. Phys. 39, 11-12, 1277-1299, DOI: 10.1016/0021-9169(77)90080-0.

Burrows, M.L. (1978), ELF Communication Antennas, Peter Peregrinus, London.

Cannon, P.S., and M.J. Rycroft (1982), Schumann resonance frequency variations during sudden ionospheric disturbances, J. Atmos. Terr. Phys. 44, 2, 201-206, DOI: 10.1016/00219169(82)90124-6.

Chapman, F.W., and D.L. Jones (1964), Earth-ionosphere cavity resonances and the propagation of extremely low frequency radio waves, Nature 202, 654-657, DOI: 10.1038/202654a0.

Clayton, M.D., and C. Polk (1977), Diurnal variation and absolute intensity of world-wide lightning activity, September 1970 to May 1971. In: H. Dolezalek and R.Reiter (eds.), Electrical Processes in Atmospheres, Steinkopff, Darmstadt, 440-449.

Coughlin, M.W., N.L. Christensen, R. De Rosa, I. Fiori, M. Golkowski, M. Guidry, J. Harms, J. Kubisz, A. Kulak, J. Mlynarczyk, F. Paoleti, and E. Thrane (2016), Subtraction of correlated noise in global networks of gravitational-wave interferometers, Class. Quantum Grav. 33, 22, 224003, DOI: 10.1088/0264-9381/33/22/224003.

Dyrda, M., A. Kulak, J. Mlynarczyk, M. Ostrowski, J. Kubisz, A. Michalec, and Z. Nieckarz (2014), Application of the Schumann resonance spectral decomposition in characterizing the main African thunderstorm center, J. Geophys. Res. - Atmos. 119, 13338-13349, DOI: 10.1002/2014 JD022613. 
Dyrda, M., A. Kulak, J. Mlynarczyk, and M. Ostrowski (2015), Novel analysis of a sudden ionospheric disturbance using Schumann resonance measurements, J. Geophys. Res. - Space 120, 2255-2262, DOI: 10.1002/2014JA020854.

Fano, U. (1961), Effects of configuration interaction on intensities and phase shifts, Phys. Rev. 124, 1866, DOI: 10.1103/PhysRev.124.1866.

Füllekrug, M. (2000), Dispersion relation for spherical electromagnetic resonances in the atmosphere, Phys. Lett. A 275, 80-89, DOI: 10.1016/S0375-9601(00)00549-1.

Füllekrug, M., A. Fraser-Smith, and K. Schlegel (2002), Global ionospheric D-layer height monitoring, Europhys. Lett. 59, 4, 626-632, DOI: 10.1209/epl/i2002-00150-y.

Galejs, J. (1961), Terrestrial extremely low frequency noise spectrum in the presence of exponential ionospheric conductivity profiles, J. Geophys. Res. 66, 9, 2787-2792, DOI: 10.1029/JZ066i009 p02787.

Galejs, J. (1965), Schumann resonances, Radio Sci. J. Res. NBS 69D, 1043-1055, DOI: 10.6028/ jres.069D.113.

Galejs, J. (1970), Frequency variations of Schumann resonances, J. Geophys. Res. 75, 16, 3237-3251, DOI: 10.1029/JA075i016p03237.

Galejs, J. (1972), Terrestrial Propagation of Long Electromagnetic Waves, Pergamon Press, New York.

Galuk, Yu.P., A.P. Nickolaenko, and M. Hayakawa (2015), Knee model: Comparison between heuristic and rigorous solutions for the Schumann resonance problem, J. Atmos. Sol.-Terr. Phys. 135, 85-91, DOI: 10.1016/j.jastp.2015.10.008.

Gołkowski, M., S.R. Sarker, C. Renick, R.C. Moore, M.B. Cohen, A. Kułak, J. Młynarczyk, and J. Kubisz (2018), Ionospheric D region remote sensing using ELF sferic group velocity, Geophys. Res. Lett. 45, 23, 12739-12748, DOI: 10.1029/2018GL080108.

Greenberg, E., and C. Price (2007), Diurnal variations of ELF transients and background noise in the Schumann resonance band, Radio Sci. 42, RS2S08, DOI: 10.1029/2006RS003477.

Greifinger, C., and P. Greifinger (1978), Approximate method for determining ELF eigenvalues in the Earth-ionosphere waveguide, Radio Sci. 13, 831-837, DOI: 10.1029/RS013i005p00831.

Greifinger, C., and P. Greifinger (1979), On the ionospheric parameters which govern high-latitude ELF propagation in the Earth-ionosphere waveguide, Radio Sci. 14, 889-895, DOI: 10.1029/RS014 i005p00889.

Heckman, S.J., E. Williams, and B. Boldi (1998), Total global lightning inferred from Schumann resonance measurements, J. Geophys. Res. 103, D24, 31775-31779, DOI: 10.1029/98JD02648.

Jones, D.L. (1964), The calculation of the Q factors and frequencies of Earth-ionosphere cavity resonances for a two-layer ionospheric model, J. Geophys. Res. 69, 19, 4037-4046, DOI: 10.1029/ JZ069i019p04037.

Jones, D.L. (1967), Schumann resonances and ELF propagation for inhomogeneous, isotropic ionosphere profiles, J. Atmos. Terr. Phys. 29, 1037-1044, DOI: 10.1016/0021-9169(67)90138-9.

Kirillov, V.V. (1993), Parameters of the Earth-ionosphere waveguide at extremely low frequencies, The Problems of Diffraction and Wave Propagation 25, 35-52.

Kirillov, V.V., and V.N. Kopeykin (2002), Solving a two-dimensional telegraph equation with anisotropic parameters, Radiophys. Quantum El. 45, 12, 929-941, DOI: 10.1023/A:102352533153.

Kirillov, V.V., V.N. Kopeykin, and V. Mushtak (1997), ELF Electromagnetic waves within the Earthionosphere wave guide, Geomagn. Aeron. 37, 114-120 (in Russian).

Kozakiewicz, J., A. Kulak, and J. Mlynarczyk (2015), Analytical modeling of Schumann resonance and ELF propagation parameters on Mars with a multi-layered ground, Planet. Space Sci. 117, 127-135, DOI: 10.1016/j.pss.2015.05.019. 
Kudintseva, I.G., A.P. Nickolaenko, M.J. Rycroft, and A. Odzimek (2016), AC and DC global electric circuit properties and the height profile of atmospheric conductivity, Ann. Geophys. - Italy 59, 5, A0545, DOI: 10.4401/ag-6870.

Kułak, A., and J. Młynarczyk (2011), A new technique for reconstruction of the current moment waveform related to a gigantic jet from the magnetic field component recorded by an ELF station, Radio Sci. 46, RS2016, DOI: 10.1029/2010RS004475.

Kulak, A., and J. Mlynarczyk (2013), ELF propagation parameters for the ground-ionosphere waveguide with finite ground conductivity, IEEE T. Antenn. Propag. 61, 4, DOI: 10.1109/TAP.2012. 2227445.

Kułak, A., S. Micek, Z. Nieckarz, and S. Zięba (2003a), Solar variations in extremely low frequency propagation parameters: I. A two-dimensional telegraph equation (TDTE) model of ELF propagation and fundamental parameters of Schumann resonances, J. Geophys. Res. 108, A7, 1270, DOI: 10.1029/2002 JA009304.

Kułak, A., J. Kubisz, A. Michalec, Z. Nieckarz, and S. Zięba (2003b), Solar variations in extremely low frequency propagation parameters: II. Observations of Schumann resonances and computation of the ELF attenuation parameter, J. Geophys. Res. 108, A7, 1271, DOI: 10.1029/2002JA 009305.

Kułak, A., J. Młynarczyk, S. Zięba, S. Micek, and Z. Nieckarz (2006), Studies of ELF propagation in the sphericall shell cavity using a field decomposition method based on asymmetry of Schumann resonance curves, J. Geophys. Res. 111, A10304, DOI: 10.1029/2005JA011429.

Kulak, A., J. Mlynarczyk, and J. Kozakiewicz (2013), An analytical model of ELF radiowave propagation in ground-ionosphere waveguides with a multilayered ground, IEEE T. Antenn. Propag. 61, 9, DOI: 10.1109/TAP.2013.2268244.

Kulak, A., J. Kubisz, S. Klucjasz, A. Michalec, J. Mlynarczyk, Z. Nieckarz, M. Ostrowski, and S. Zieba (2014), Extremely low frequency electromagnetic field measurements at the Hylaty station and methodology of signal analysis, Radio Sci. 49, 6, 361-370, DOI: 10.1002/2014RS005400.

Madden, T., and W. Thompson (1965), Low-frequency electromagnetic oscillations of the Earth-ionosphere cavity, Rev. Geophys. 3, 2, 211-254, DOI: 10.1029/RG003i002p 00211.

Magunia, A. (1996), The thunderstorm-driven diurnal variation of the ELF electromagnetic activity level, J. Atmos. Terr. Phys. 58, 15, 1683-1697, DOI: 10.1016/0021-9169(95)00156-5.

Mlynarczyk, J., J. Bor, A. Kulak, M. Popek, and J. Kubisz (2015), An unusual sequence of sprites followed by a secondary TLE - an analysis of ELF radio measurements and optical observations, J. Geophys. Res. 120, DOI: 10.1002/2014JA020780.

Mlynarczyk, J., A. Kulak, and J. Salvador (2017a), The accuracy of radio direction finding in the extremely low frequency range, Radio Sci. 52, 1245-1252, DOI: 10.1002/2017RS006370.

Mlynarczyk, J., A. Kulak, and J. Kubisz (2017b), Radiolocating strong ELF electromagnetic pulses using two receivers placed on different continents. In: Proc. of the 21st Int. Conf. on Microwave, Radar and Wireless Communications (MIKON), IEEE, DOI: 10.1109/MIKON.2016.7492093.

Mushtak, V.C., and E.R. Williams (2002), ELF propagation parameters for uniform models of the Earth-ionosphere waveguide, J. Atmos. Sol.-Terr. Phys. 64, 1989-2001, DOI: 10.1016/S13646826(02)00222-5.

Neska, M., and G. Sátori (2006), Obserwacje rezonansu Schumanna w Polskiej Stacji Polarnej na Spitsbergenie oraz Obserwatorium Geofizycznym w Belsku [Schumann resonance observation at Polish Polar Station at Spitsbergen and Geophysical Observatory in Belsk], Prz. Geof. 51, 3-4, 189-198.

Nickolaenko, A.P. (1997), Modern aspects of Schumann resonance studies, J. Atmos. Sol.-Terr. Phys. 59, 805-816, DOI: 10.1016/S1364-6826(96)00059-4. 
Nickolaenko, A.P., and L.M. Rabinowicz (1995), Study of the annual changes of global lightning distribution and frequency variations of the first Schumann resonance mode, J. Atmos. Terr. Phys. 57, 11, 1345-1348, DOI: 10.1016/0021-9169(94)00114-4.

Nickolaenko, A.P., G. Sàtori, B. Zieger, L.M. Rabinowicz, and I.G. Kudintseva (1998), Parameters of global thunderstorm activity deduced from the long-term Schumann resonance records, $J$. Atmos. Sol.-Terr. Phys. 60, 3, 387-399, DOI: 10.1016/S1364-6826(97)00121-1.

Nickolaenko, A.P., Y.P. Galuk, and M. Hayakawa (2016), Vertical profile of atmospheric conductivity that matches Schumann resonance observations, SpringerPlus 5, 108, DOI: 10.1186/s40064016-1742-3.

Nieckarz, Z., S. Zieba, A. Kułak, and A. Michalec (2009a), Study of the periodicities of lightning activity in three main thunderstorm centers based on Schumann resonance measurements, Mon. Weather Rev. 137, 12, 4401-4409, DOI: 10.1175/2009MWR2920.1.

Nieckarz, N., A. Kułak, S. Zięba, M. Kubicki, S. Michnowski, and P. Baranski (2009b), Comparison of global storm activity rate calculated from Schumann resonance background components to electric field intensity E0z, Atmos. Res. 91, 184-187, DOI: 10.1016/j.atmosres.2008.06.006.

Odzimek, A., and M. Lester (2009), Modelling the Earth's Global Atmospheric Electric Circuit - Development, challenges and directions, Publs. Inst. Geophys. Pol. Acad. Sci. D-73 (412), 37-53.

Ogawa, T., Y. Tanaka, T. Miura, and M. Yasuhara (1966), Observations of natural ELF electromagnetic noises by using the ball antennas, J. Geomagn. Geoelectr. 18, 443-454, DOI: 10.5636/ jgg.18.443.

Ogawa, T., Y. Tanaka, and M. Yasuhara (1968), Diurnal variations of resonance frequencies in the Earth-ionosphere cavity, Special Contrib. Geophys. Inst. Kyoto Univ. 8, 15-20.

Pechony, O., and C. Price (2004), Schumann resonance parameters calculated with a partially uniform knee model on Earth, Venus, Mars and Titan, Radio Sci. 39, RS5007, DOI: 10.1029/2004RS 003056.

Pierce, E.T. (1963), Excitation of earth-ionosphere resonances by lightning flashes, J. Geophys. Res. 68, 4125, DOI: 10.1029/JZ068i013p04125.

Polk, C. (1969), Relation of ELF noise and Schumann resonances to thunderstorm activity. In: S. Coroniti and J. Hughes (eds.), Planetary Electrodynamics, Vol. 2, Gordon and Breach, New York, 55-83.

Polk, C., and J. Toomey (1972), Location of major thunderstorm regions by analysis of the electric and magnetic field spectra at ELF. In: Report of Proceedings: XV General Assembly, Moscow, July-August 1971, International Association of Meteorology and Atmospheric Physics 15, 156.

Roldugin, V.C., Y.P. Maltsev, G.A. Petrova, and A.N. Vasiljev (2001), Decrease of the first Schumann resonance frequency during solar proton events, J. Geophys. Res. 106, 9, 18555-18562, DOI: $10.1029 / 2000 J$ A900118.

Row, R.V. (1962), On the electromagnetic resonant frequencies of the Earth-ionosphere cavity, IRE T. Antenn. Propag., AP-10, 766.

Rycroft, M.J. (1965), Resonances of the Earth-ionosphere cavity observed at Cambridge, England, Radio Science J. Res. NBS UNSC-URSI 69D, 8, 1071-1081, DOI: 10.6028/jres.069D.115.

Rycroft, M.J., S. Israelsson, and C. Price (2000), The global atmospheric electric circuit, solar activity and climate change, J. Atmos. Sol.-Terr Phys. 62, 17, 1563-1576, DOI: 10.1016/S13646826(00)00112-7.

Sátori, G. (1996), Monitoring Schumann resonances II. Daily and seasonal frequency variations, $J$. Atmos. Terr. Phys. 58, 1483-1488, DOI: 10.1016/0021-9169(95)00146-8.

Sátori, G., E. Williams, and V. Mushtak (2005), Response of the Earth-ionosphere cavity resonator to the 11-year solar cycle in X-radiation, J. Atmos. Sol.-Terr. Phys. 67, 553-562, DOI: 10.1016/ j.jastp.2004.12.006. 
Sátori, G., E. Williams, C. Price, R. Boldi, A. Koloskov, Y. Yampolski, A. Guha, and V. Barta (2016), Effects of energetic solar emissions on the Earth-ionosphere cavity of Schumann resonances, Surv. Geophys. 37, 4, 757-789, DOI: 10.1007/s10712-016-9369-z.

Schlegel, K., and M. Füllekrug (1999), Schumann resonance parameter changes during high-energy particle precipitation, J. Geophys. Res. 104, A5, 10111-10118, DOI: 10.1029/1999JA900056.

Schumann, W.O. (1952a), Über die strahlungslosen Eigenschwingungen einer leitenden Kugel, die von einer Luftschicht und einer Ionosphärenhülle umgeben ist, Z. Naturforsch. A 7, 2, 149154, DOI: 10.1515/zna-1952-0202.

Schumann, W.O. (1952b), Über die Dämpfung der elektromagnetischen Eigenschwingnugen des Systems Erde-Luft-Ionosphäre, Z. Naturforsch. A 7, 3-4, 250-252, DOI: 10.1515/zna-1952-3-404.

Schumann, W.O. (1952c), Über die Ausbreitung sehr langer elektriseher Wellen um die Erde und Signale des Blitzes, Nuovo Cim. 9, 12, 1116-1138, DOI: 10.1007/BF02782924.

Schumann, W.O., and H. König (1954), Über die Beobactung von "atmospherics" bei geringsten Frequenzen, Naturwissensch. 41, 8, 183-184, DOI: 10.1007/BF00638174.

Sentman, D.D. (1983), Schumann resonance effect of electrical conductivity perturbations in an exponential atmospheric/ionospheric profile, J. Atmos. Terr. Phys. 45, 55-65, DOI: 10.1016/S0021-9169(83)80008-7.

Sentman, D.D. (1990), Approximate Schumann resonance parameters for a two-scale-height ionosphere, J. Atmos. Terr. Phys. 52, 1, 35-46, DOI: 10.1016/0021-9169(90)90113-2.

Sentman, D.D. (1996), Schumann resonance spectra in a two-scale-height Earth-ionosphere cavity, J. Geophys. Res.101, D5, 9479-9487, DOI: 10.1029/95JD03301.

Sentman, D.D., and B.J. Fraser (1991), Simultaneous observations of Schumann Resonances in California and Australia - Evidence for intensity modulation by the local height of the D region, J. Geophys. Res. 96, 9, 5973-15984, DOI: 10.1029/91JA01085.

Shvets, A.V. (2001), A technique of reconstruction of global lightning distance profile from background Schumann resonance signal, J. Atmos. Sol.-Terr. Phys. 63, 1061-1074, DOI: 10.1016/S1364-6826(01)00024-4.

Tran, A., and C. Polk (1979), Schumann resonances and electrical conductivity of the atmosphere and lower ionosphere - I. Effects of conductivity at various altitudes on resonance frequencies and attenuation, J. Atmos. Terr. Phys. 41, 12, 1241-1248, DOI: 1016/0021-9169(79)90027-8.

Wait, J.R. (1962), On the propagation of ELF pulses in the Earth-ionosphere waveguide, Canadian J. Phys. 40, 10, 1360-1369, DOI: 10.1139/p62-143.

Wait, J.R. (1972), Project Sanguine, Science 178, 4058, 272-275, DOI: 10.1126/science.178.4058. 272.

Wait, J.R. (1977), Propagation of ELF electromagnetic waves and Project Sanguine/Seafarer, IEEE J. Oceanic Eng. OE-2, 2, 161-172.

Williams, E.R. (1992), The Schumann Resonance: a global tropical thermometer, Science 256, 11841188, DOI: $10.1126 /$ science.256.5060.1184.

Williams, E.R., and G. Sátori (2007), Solar radiation-induced changes in ionospheric height and the Schumann resonance waveguide on different timescales, Radio Sci. 42, RS2S11, DOI: 10.1029/ 2006RS003494.

Williams, E.R., V.C. Mushtak, and A.P. Nickolaenko (2006), Distinguishing ionospheric models using Schumann resonance spectra, J. Geophys. Res. 111, D16107, DOI: 10.1029/2005JD006944.

Williams, E., A. Guha, R. Boldi, H. Christian, and D. Buechler (2019), Global lightning activity and the hiatus in global warming, J. Atmos. Sol.-Terr. Phys. 189, 27-34, DOI: 10.1016/j.jastp.2019. 03.011.

Yang, H., V.P. Pasko, and G. Sátori (2009), Seasonal variations of global lightning activity extracted from Schumann resonances using a genetic algorithm method, J. Geophys. Res. 114, D01103, DOI: 10.1029/2008JD009961. 


\section{WSPÓŁCZESNE BADANIA REZONANSU SCHUMANNA}

\section{Streszczenie}

Opublikowana przez W.O. Schumanna praca o wnęce Ziemia-jonosfera otwarła nowe kierunki badań (Schumann 1952a, b, c). Pierwszy związany jest z fizyką falowodów gruntjonosfera i modelowaniem propagacji w zakresie ELF. Drugi koncentruje się na pomiarach wyładowań atmosferycznych, efektywnych w tym zakresie częstotliwości ze względu na dalekozasięgową propagację fal. Przeprowadzona przez M. Balsera i C.A. Wagnera pierwsza udana obserwacja naturalnego pola rezonansu Schumanna we wnęce (Balser i Wagner 1960) wywołała znaczne zainteresowanie. Pierwsze badania koncentrują się na analizie spektralnej i zmienności szumów atmosferycznych (Balser i Wagner 1962, Pierce 1963, Blackband 1964, Rycroft 1965, Polk 1969), oraz modelowaniu wnęki (Row 1962, Wait 1962, Jones 1964, Chapman i Jones 1964, Galejs 1965, 1970; Rycroft 1965, Madden i Thompson 1965, Jones 1967, Booker i Lefeuvre 1977, Tran i Polk 1979, Bliokh i in. 1980).

Falowód grunt-jonosfera modelowano początkowo przy pomocy pełnofalowej metody rozwiązań 3D. Nowy etap modelowania przyniosła praca Maddena i Thompsona (1965), w której autorzy postulują przyjęcie modelu TDTE (Two-Dimensional Telegraph Equations), w którym falowód zostaje zastąpiony dwuwymiarową sferyczną linią transmisyjną, w której równania polowe Maxwella zostają zastąpione równaniami telegrafistów dla napięć i prądów.

Pod koniec lat siedemdziesiątych C. i P. Greifingerowie (Greifinger and Greifinger 1978, 1979) dokonują kolejnego przełomu w modelowaniu falowodu grunt-jonosfera. Analizując mechanizmy wnikania składowej elektrycznej i magnetycznej pola fali do jonosfery, wprowadzają dwie różniące się od siebie wysokości charakterystyczne falowodu: wysokość elektryczną $h_{e}$ i wysokość magnetyczną $h_{m}$. Wkrótce Kirillov (Kirillov 1993, Kirillov i in. 1997, Kirillov i Kopeykin 2002) zauważa, że wysokości charakterystyczne Greifingerów $h_{e}$ i $h_{m}$ są ściśle związane z parametrami jednostkowymi L i C dwuwymiarowej linii transmisyjnej, wprowadzonej przez Maddena i Thompsona (1965). Wysokości charakterystyczne stają się podstawowymi parametrami falowodu grunt-jonosfera pozwalającymi rozwiązywać w zakresie ELF zagadnienia propagacyjne i zjawiska rezonansowe we wnęce grunt-jonosfera (Kirillov i in. 1997, Mushtak i Williams 2002, Williams i in. 2006, Pechony i Price 2004, Kulak i Mlynarczyk 2013, Kulak i in. 2013, Galuk i in. 2015, Kudintseva i in. 2016).

$\mathrm{Z}$ biegiem lat badania obserwacyjne koncentrują się na pomiarach zmienności parametrów rezonansu Schumanna i poszukiwania ich przyczyn (Ogawa i in. 1968, Polk i Toomey 1972, Nickolaenko i Rabinowicz 1995, Nickolaenko 1997, Nickolaenko i in. 1998, Sátori 1996, Neska i Sátori 2006, Greenberg i Price 2007). Badane są zależności amplitud i częstotliwości poszczególnych modów rezonansu od czasu i przestrzennego rozkładu wyładowań atmosferycznych. Analizowany jest wpływ zaburzeń górnych warstw jonosfery na stan wnęki spowodowany gwałtownymi wzrostami aktywności słonecznej (Blackband 1964, Cannon i Rycroft 1982, Magunia 1996), oraz długoczasowe zmiany parametrów wnęki w przedziałach czasu obejmujących 11-letni cykl aktywności słonecznej (Kulak i in. 2003b, Sátori i in. 2005). Powstają prace modelowe uwzględniające wpływ różnych rodzajów zaburzeń na stan wnęki (Galejs 1972, Sentman 1983, Füllekrug 2000, Füllekrug i in. 2002, Williams i Sátori 2007, Sátori i in. 2016).

Williams (1992) wykazał, że amplituda 1 modu rezonansu Schumanna wzrasta wraz ze wzrostem średniej temperatury powietrza w tropikach, co otworzyło nowe możliwości pre- 
cyzyjnego monitorowania klimatu (Rycroft i in. 2000, Williams i in. 2019). Już wcześniej w szeregu prac podejmowano próby odtwarzania globalnej aktywności burzowej na podstawie obserwacji widm rezonansu Schumanna. Wykorzystywano w tym celu uproszczone rozwiązania analityczne oparte na metodzie rozdzielenia zmiennych, opisujące składową rezonansową pola we wnęce (Galejs 1972, Clayton i Polk 1977, Polk i Toomey 1972, Heckman i in. 1998, Nickolaenko i Rabinowicz 1995, Nickolaenko i in. 1998, Shvets 2001, Yang i in. 2009). Analiza ścisłych rozwiązań niejednorodnych równań pola, uwzględniających czasoprzestrzenny mechanizm wypełniania wnęki przez punktowe źródło fal ujawniła, że istnieją znaczne odstępstwa realnego rozkładu pól we wnęce od uproszczonego, wynikającego z rozwiązań uzy-skiwanych metodą rozdzielenia zmiennych (Kulak i in. 2003a). Zastosowanie pełnych rozwiązań do rozwiązywania zagadnień odwrotnych otwarło nowy etap w badaniach rozmieszczenia źródeł i pomiarach parametrów wnęki (Kulak i in. 2003b).

Kolejnym etapem w badaniach pól we wnęce Ziemia-jonosfera było opracowanie metody dekompozycji widm mocy rezonansu Schumanna, opartej na idei rezonansu Fano (Fano 1961, Kulak i in. 2006). Zastosowanie metody dekompozycji do analizy obserwacyjnych widm mocy rezonansu Schumanna otwarło nową drogę do precyzyjnych pomiarów parametrów wnęki Ziemia-jonosfera. Pierwsze zastosowanie nowej metody dotyczyło badań przebiegu globalnego indeksu intensywności burzowej, opisującego dobowe przebiegi aktywności trzech światowych centrów burzowych (Nieckarz i in. 2009a). W innej pracy pokazano, że w wybranych przedziałach czasu indeks intensywności burz ściśle koreluje z wartością pola $E_{0 z}$ związanego z potencjałem jonosfery (Nieckarz i in. 2009b). Wyniki te pokazują, że metoda dekompozycji otwiera nowe możliwości dla szacowania roli aktywności burzowej w globalnym obwodzie elektrycznym atmosfery, oprócz innych możliwości w tym kierunku wynikających z analizy promieniowania ELF od wyładowań (Odzimek i Lester 2009).

Zastosowanie metody dekompozycji widm przyczyniło się do znacznej poprawy efektywności rozwiązań odwrotnych. Przy ich zastosowaniu przeprowadzono badania dobowe i sezonowe położenia oraz intensywności afrykańskiego centrum burzowego (Dyrda i in. 2014). Otwarły się nowe możliwości mapowania globalnej aktywności burzowej, szczególnie skuteczne przy zastosowaniu wielu stacji obserwacyjnych umieszczonych na kilku kontynentach. Innym zastosowaniem metody dekompozycji jest możliwość prowadzenia pomiarów parametrów wnęki Ziemia-jonosfera $\mathrm{z}$ czasową zdolnością rozdzielczą sięgającą pojedynczych minut. Umożliwiło to śledzenie gwałtownych zmian parametrów wywołanych silnymi rozbłyskami słonecznymi (Dyrda i in. 2015).

Obecne badania koncentrują się na dokładniejszym modelowaniu wysokości charakterystycznych sferycznego falowodu Ziemia-jonosfera, przy uwzględnieniu wpływu terminatorów i globalnych niejednorodności jonosfery (Kudintseva i in. 2016, Nickolaenko i in. 2016). Umożliwia to doskonalenie rozwiązań odwrotnych stosowanych do odtwarzania momentów prądowych źródeł obserwowanych przy pomocy globalnego systemu WERA (Kułak i Młynarczyk 2011, Mlynarczyk i in. 2015, 2017a, b; Gołkowski i in. 2018). Globalny system WERA odegrał ważną rolę w weryfikacji wpływu pól elektromagnetycznych ELF na pracę detektorów fal grawitacyjnych LIGO (Coughlin i in. 2016). Dzięki zaawansowanemu modelowaniu propagacji i doskonaleniu metod odwrotnych, pomiary parametrów wyładowań $\mathrm{i}$ aktywności centrów burzowych są prowadzone $\mathrm{w}$ jednostkach bezwzględnych $\mathrm{z}$ coraz większą dokładnością. W najbliższych latach odegrają one ważną rolę w śledzeniu zmian klimatu w skali globalnej (Williams i in. 2019). 



\title{
Application \\ of the Schumann Resonance Spectral Decomposition for the Analysis of Earth-Ionosphere Cavity Attenuation
}

\author{
Zenon NIECKARZ ${ }^{1, \bowtie}$, Stanisław ZIĘBA ${ }^{2}$, and Grzegorz MICHAŁEK ${ }^{2}$ \\ ${ }^{1}$ Instytute of Physics, Jagiellonian University, Kraków, Poland \\ ${ }^{2}$ Astronomical Observatory, Jagiellonian University, Kraków, Poland \\ zenon.nieckarz@uj.edu.pl
}

\section{INTRODUCTION}

The measurement and assessment of global thunderstorm activity is an important and frequent aspect of both meteorological and climatic as well as geophysical research. The assessment of this activity can be considered on the basis of indicators based on the intensity and frequency of the occurrence of various phenomena and processes, such as storm clouds (Kohl 1980), their altitude, wind speed, precipitation intensity (Twardosz 2010), the frequency of atmospheric lightning discharges (Christian et al. 2003). Such indicators are developed on the basis of observations and results of measurements carried out on the ground surface (Nieckarz and Zięba 2013) and by instruments placed on satellites (Turman 1978, Dai 2001).

Among measurements that use electromagnetic (EM) waves to monitor lightning activity, measurements of EM waves of extremely low frequency range (ELF, 3-3000 Hz) deserve particular attention. The broadband electromagnetic excitation which is each atmospheric lightning discharge excites in this frequency range a resonance in the resonant cavity constituted by the surface of the Earth and the ionosphere (E-i). For ELF waves, which have low frequencies, both the Earth's surface and the lower part of the ionosphere, the ionospheric D, E-layer and the lower part of the F-layer are well-reflective surfaces. As a result of the multiple circulation of waves around the Earth and their mutual interference - the spectrum of ELF waves is created (Fig. 1), with a specific resonant character (Schumann 1952), the so-called Schumann resonance (SR) spectrum. In the amplitude and shape of this spectrum we can find information not only about storm activity, but also about the Earth-ionosphere cavity damping.

The previous classical analysis of the SR spectrum consists of a fitting symmetric Lorentz curves to the observational spectra (Sentman 1996, Mushtak and Williams 2002). Unfortunately, this approach leads to the determination of the values of the E-i resonator's "own" frequencies, which are different even for NS and EW antennas working within one measurement station. A new approach described under the name of the ELF spectrum decomposition is shown

(C) 2019 Institute of Geophysics, Polish Academy of Sciences 
in the paper of Kułak et al. (2006), where a method of correct determination of the E-i cavity's own, i.e. the resonance frequencies (eigenfrequencies), for both perpendicularly arranged antennas working within one measurement station was described. Knowing the correct values of the cavity's own frequencies makes it possible to calculate the E-i resonant cavity damping, and is one of the elements reflecting the space weather condition in the immediate vicinity of the Earth.

The use of the power spectrum decomposition method and the acquisition of information about the E-i cavity damping based on ELF measurements made by two stations with very different locations and structures is the subject of analyses presented in this paper.

\section{SOURCE OF DATA}

This paper utilises the results of ELF measurements made by two ELF stations: a) the station named Hylaty in the Bieszczady Mountains (SE Poland) and b) the Yon station working in Yongsheng County, Yunnan province in China. The results of measurements collected in the period from 2011.05.31 (16:00 UTC) to 2011.06.09 (16:00 UTC) were analysed. The stations differ significantly in many respects, including the power supply, antenna and recorder design, digitalisation parameters, bandwidth. The orthodromic distance between the two stations is $6980 \mathrm{~km}$.

\subsection{The ELF Hylaty station (Poland, Europe)}

ELF measurements in the Bieszczady Mountains (SE Poland, $22.5^{\circ} \mathrm{E}, 49.1^{\circ} \mathrm{N}$ ) are conducted by the Astronomical Observatory of the Jagiellonian University in Kraków. Continuous measurements have been carried out since 2005. The station is equipped with two active magnetic antennas (solenoids), a recorder and a set of batteries that provide power supply for a period of over 2 months. After this time, the memory card in the recorder is replaced, and the measurement results are delivered to Kraków to be analysed and archived. The battery pack, however, is charged in the field with the use of a power generator. Charging time is about 10 hours. The recorder and batteries are placed in an underground tank, which protects the apparatus mechanically and stabilises the thermal conditions of the apparatus (Nieckarz 2016). Both antennas are arranged horizontally in accordance with the geographical directions of NS and EW, at a distance of $100 \mathrm{~m}$ from the recorder. The antennas are $1 \mathrm{~m}$ long and are powered from the recorder module. The $3 \mathrm{~dB}$ frequency bandwidth of the station is $0.03-55 \mathrm{~Hz}$ and the sampling frequency equals $175 \mathrm{~Hz}$. The amplitude input range is +/- $1.8 \mathrm{nT}$ with 16-bit dynamics. The station measures the signal from the antennas, which is subjected to integration and thanks to this the recorder records the values proportional to the magnetic field induction $(B)$. A detailed description of the apparatus can be found in the paper by Kułak et al. (2014).

\subsection{The ELF Yongsheng station (China, Asia)}

The Yon ELF station conducts ELF measurements in Yongsheng County $\left(100.8^{\circ} \mathrm{E}, 26.7^{\circ} \mathrm{N}\right)$, Yunnan province in China. It was established in 2009 with the original intention to monitor earthquakes so that only magnetic component ( $\left.\mathrm{B}_{\mathrm{NS}}, \mathrm{B}_{\mathrm{EW}}\right)$ antennas are installed. The $3 \mathrm{~dB}$ frequency bandwidth of the station is $3-29 \mathrm{~Hz}$, and the sampling frequency equals to $100 \mathrm{~Hz}$. The sampling data is saved to a local computer, and then they are available via the Internet in quasireal-time (Ouyang et al. 2015). All of it is powered from the power grid. The station measures the signal from the antennas and does not use the integrating ratio. As a consequence, the recorded signal is proportional to the magnetic field induction derivative $(d B / d t)$. 


\subsection{Comparison of ELF spectrum}

Figure 1 presents power spectra obtained in both stations. There are clear differences in the nature of the spectra, especially in the bandwidth of both measuring systems. The spectra also contain narrow lines and distortions in various frequency ranges, which indicates a diverse level of electromagnetic noise from human activity (power grids, proximity of populated areas and roads).
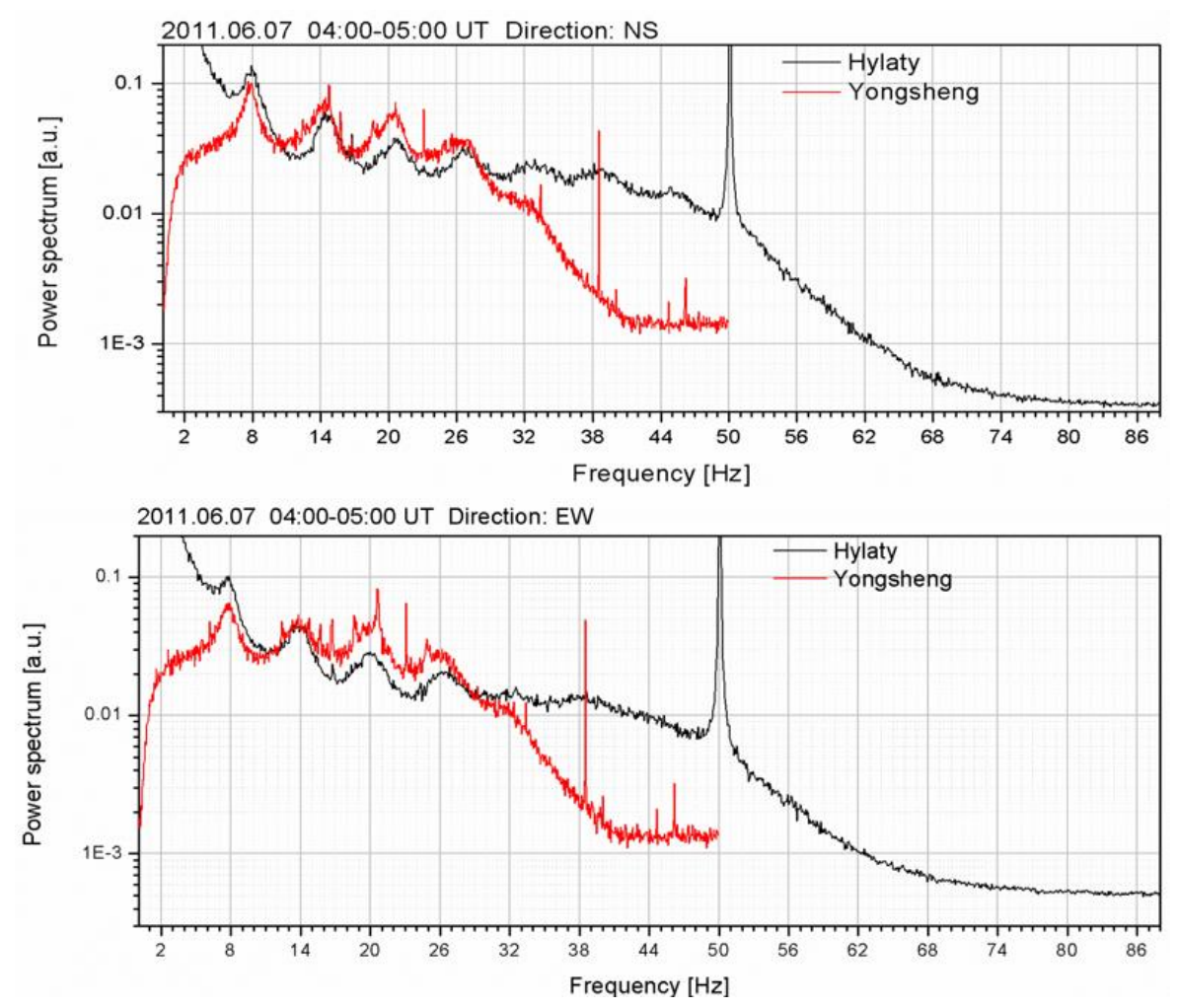

Fig. 1. The comparison of average hourly radiation power spectra in the ELF range, which were recorded with NS antennas (the upper graph) and EW antennas (the bottom graph) by the ELF Hylaty station in the Bieszczady Mountains (black line) and the ELF Yon station in Yongsheng (red line).

\section{METHOD OF ANALYSIS}

Firstly, average daily power spectra were calculated for the collected measurement results for each station and each antenna separately using Fast Fourier Transform algorithm (Cooley and Tukey 1965). Next, analytical power spectrum was fitted to each spectrum, in accordance with formula in Eq. 1 in the 4-24 Hz frequency range, where: $\left|B_{t}(f)\right|^{2}-$ is the theoretical summary power spectrum; $w$ - the amplitude of the power spectrum of white noise; $z$ - the amplitude of the colour spectrum noise; $\alpha$-spectral parameter of colour noise; $n$-is the number of resonance mode; $a_{n}$-describes the power of the $n$ resonance mode, the value of which depends on the distance of the signal source from the measurement station; $e_{n}-$ is the asymmetry parameter; $f_{n}$ and $\Gamma_{n}$ are mean reduced resonance frequency and a half of the reduced resonance width.

$$
\left|B_{t}(f)\right|^{2}=w+\frac{z}{f^{\alpha}}+\sum_{n=1}^{3} \frac{a_{n} \cdot\left[1+e_{n} \cdot\left(f-f_{n}\right)\right]}{\left(f-f_{n}\right)^{2}+\left(\Gamma_{n}\right)^{2}}
$$

The selected frequency range includes the first three Schumann resonance modes, and at the same time can be applied to both types of data. The applied analytical formula was developed 
and applied in the paper by Kulak et al. (2006), with the use of test spectra obtained from a numerical model based on the application of the two-dimensional telegraph equations (TDTE) and tested for a small sample of real spectra recorded by the ELF Hylaty station (Kułak et al. 2006), and has also been successfully used to determine the distance between the African storm centre and the Hylaty station (Dyrda et al. 2014).

Due to local storm activity it was not possible to perform spectrum analysis for every hour. Some results were rejected due to the huge interferences coming from very close discharges. The majority of such cases concerned the Hylaty station.

For all qualified observational spectra from both stations, analyses were carried out using the identical fitting procedure, in which noise and the first three resonance modes were taken into account.

\section{RESULTS}

As a result of fitting the analytic function (Eq. 1) to the spectra obtained from measurements, the following were determined: frequency value, full width at half maximum, asymmetry coefficient and amplitude for each $n$-th resonance peak $\left(f_{n}, \Gamma_{n}, e_{n}, a_{n}\right)$. Frequency course $f_{1}$ for both stations and for each antenna (NS and EW) as a function of time is shown in Fig. 2. The graph shows that courses of value $f_{1}$ in both antennas are characterised by the distinctly cyclical variability (especially in the Hylaty station) and are mutually correlated. Large diurnal variations of the determined average hourly frequencies $f_{1}$ partly result from storms that occurred in the vicinity of the Hylaty station, which hindered the analysis of power spectra; however, aspect of diurnal variation of $f_{1}$ is not the subject of this paper.
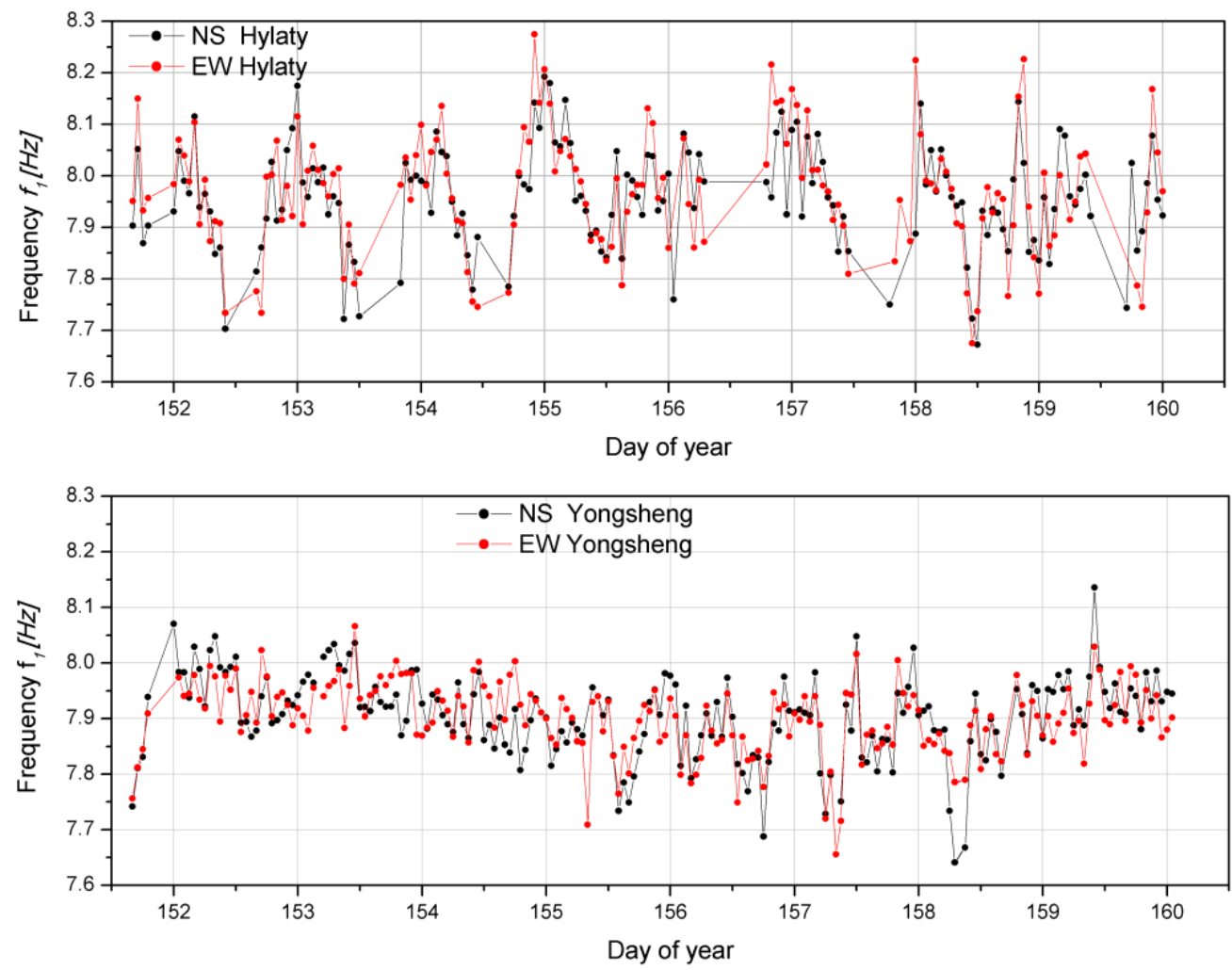

Fig. 2. Waveforms of hourly frequency values $f_{1, \mathrm{NS}}$ (black) and $f_{1 \text {,EW }}$ (red) of the first Schumann resonance mode determined on the basis of measurements conducted by the Hylaty ELF station (the upper graph) and Yon ELF station (the bottom graph) from 2011.05 .31 (16:00 UTC) to 2011.06.09 (16:00 UTC). 
Based on the results shown in the graph (Fig. 2), the average frequency values for the first resonant peak for both antennas were calculated for each station $\left(\left\langle f_{1}\right\rangle_{\mathrm{NS}},\left\langle f_{1}\right\rangle_{\mathrm{EW}}\right)$ and presented in the table (Table 1) along with their standard deviation $(S D)$. The standard error of the mean in all cases does not exceed $\pm 0.01 \mathrm{~Hz}$. It is easy to see that the $\left\langle f_{1}\right\rangle$ values in Table 1 are consistent.

Table 1

The average frequency values of the first resonance mode calculated for the Hylaty ELF and Yon ELF stations for the NS and EW directions; the $S D$ is the standard deviation

\begin{tabular}{|c|c|c|}
\hline Station & $\begin{array}{c}\text { Direction NS } \\
\left\langle f_{1}\right\rangle_{\mathrm{NS}} \pm S D\end{array}$ & $\begin{array}{c}\text { Direction EW } \\
\left\langle f_{1}\right\rangle_{\mathrm{EW}} \pm S D\end{array}$ \\
\hline ELF Hylaty & $7.96 \pm 0.10$ & $7.97 \pm 0.12$ \\
\hline ELF Yon & $7.90 \pm 0.10$ & $7.90 \pm 0.07$ \\
\hline
\end{tabular}

The maximum value of the average is $7.97 \mathrm{~Hz}$ and the minimum $7.90 \mathrm{~Hz}$, thus the average value span is $0.07 \mathrm{~Hz}$. However, within one station the difference between frequencies $\left\langle f_{1}\right\rangle$ for NS and EW directions does not occur or is very small $(0.01 \mathrm{~Hz})$ for the ELF Yon and ELF Hylaty stations, respectively.

The calculated average frequency $f_{1}$, based on all values from the table (Table 1), is $7.93 \mathrm{~Hz}$. Knowing the $f_{1}$ value we can, based on the results presented in the paper (Kulak et al. 2006), determine the average damping value of the Earth-ionosphere resonant cavity $(\chi)$ in the analysed period, which amounted to $\chi=3.43 \times 10^{-6} \Omega \mathrm{m}^{-1} \mathrm{~Hz}^{-1 / 2}$.

\section{CONCLUSIONS}

In spite of significant differences in the construction of the measuring apparatus, the frequency range of the recorded frequencies (Hylaty: 0.03-55 Hz, Yon: 3-29 Hz) and recorded physical quantity (Hylaty: B - magnetic field induction, Yon: $d B / d t-$ a derivative of magnetic induction), the same frequency, within the limits of the error, of the first Schumann resonance mode $\left(f_{1}\right)$ in NS and EW antennas for both stations was obtained.

The obtained result indicates that the application of the asymmetrical model to the Schumann resonance spectrum is correct and allows for the correct determination of the average frequency value of the first SR mode despite using the apparatus with different characteristics. As a consequence, it is possible to determine the E-i resonant cavity damping value, which for the analysed period 2011/05/31 - 2011/06/09 was $3.43 \times 10^{-6} \Omega \mathrm{m}^{-1} \mathrm{~Hz}^{-1 / 2}$.

The data from the analysed period was included in detailed analysis in the Passive Interval (PI) of 24 Solar Cycle (Zięba and Nieckarz 2014), and from the classical point of view, it is classified into the growth phase of the 24th solar cycle, in which the average sunspot number is 90.4. The obtained result of the E-i cavity damping is close to the damping range obtained by another method (Kułak et al. 2003) for the growth phase of the 23th solar cycle.

Acknowledgments. Zenon Nieckarz and Grzegorz Michałek were supported by NCN through the grant UMO-2017/25/B/ST9/00536. Authors thank Prof. Qilin Zhang and Feng Yin from The College of Atmospheric Physics in the University of Nanjing Information Science and Technology for sharing data from the Chinese station as well as Jerzy Kubisz and Adam Michalec from the Astronomical Observatory of Jagiellonian University for providing and archiving data from the Hylaty station. 


\section{References}

Christian, H.J., R.J. Blakeslee, D.J. Boccippio, W.L. Boeck, D.E. Buechler, K.T. Driscoll, S.J. Goodman, J.M. Hall, W.J. Koshak, D.M. Mach, and M.F. Stewart (2003), Global frequency and distribution of lightning as observed from space by the optical transient detector, J. Geophys. Res. 108, D1, 4005, DOI: 10.1029/2002JD002347.

Cooley, J.W., and J.W. Tukey (1965), An algorithm for the machine calculation of complex Fourier series, Math. Comput. 19, 297-301, DOI: 10.1090/S0025-5718-1965-0178586-1.

Dai, A. (2001), Global precipitation and thunderstorm frequencies. Part I: seasonal and interseasonal variation. J. Climatol. 14, 1092-1111, DOI: 10.1175/1520-0442(2001)014<1092:GPATFP> 2.0.CO;2.

Dyrda, M., A. Kulak, J. Mlynarczyk, M. Ostrowski, J. Kubisz, A. Michalec, and Z. Nieckarz (2014), Application of the Schumann resonance spectral decomposition in characterizing the main African thunderstorm center, J. Geophys. Res. - Atmos. 119, 13338-13349, DOI:10.1002/ 2014JD022613.

Kohl, D.A. (1980), An evaluation of the Area Thunderstorm Monitor in an operational application, Bull. Amer. Meteorol. Soc. 61, 9, 993-997, DOI: 10.1175/1520-0477(1980)061<0993:AEOTAT> 2.0.CO;2.

Kułak, A., J. Kubisz, A. Michalec, S. Zięba, and Z. Nieckarz (2003), Solar variations in extremely low frequency propagation parameters: 2. Observations of Schumann resonances and computation of the ELF attenuation parameter, J. Geophys. Res. 108, A7, 1271, DOI: 10.1029/2002JA 009305.

Kułak, A., J. Młynarczyk, S. Zięba, S. Micek, and Z. Nieckarz (2006), Studies of ELF propagation in the spherical shell cavity using a field decomposition method based on asymmetry of Schumann resonance curves, J. Geophys. Res. 111, A10304, DOI:10.1029/2005JA011429.

Kułak, A., J. Kubisz, S. Kłucjasz, A. Michalec, J. Młynarczyk, Z. Nieckarz, M. Ostrowski, and S. Zięba (2014), Extremely low frequency electromagnetic field measurements at the Hylaty station and methodology of signal analysis, Radio Sci. 49, 6, 361-370, DOI: 10.1002/ 2014RS005400.

Mushtak, V.C., and E.R. Williams (2002), ELF propagation parameters for uniform models of the Earthionosphere waveguide, J. Atmos. Sol.-Terr. Phys. 64, 1989-2001, DOI: 10.1016/S1364-6826 (02)00222-5.

Nieckarz, Z. (2016), Imprints of natural phenomena and human activity observed during 10 years of ELF magnetic measurements at the Hylaty Geophysical Station in Poland, Acta Geophys. 64, 6, 2591-2608, DOI: 10.1515/acgeo-2016-0101.

Nieckarz, Z., and S. Zięba (2013), Numerical estimate of daily thunderstorm surface area and its use in the analysis of extreme weather phenomena in Poland and Europe in 1980-2010, Atmos. Res. 127, 77-89, DOI: 10.1016/j.atmosres.2013.02.007.

Ouyang, X.Y., Z. Xiao, Y.Q. Hao, and D.-H. Zhang (2015), Variability of Schumann resonance parameters observed at low latitude stations in China, Adv. Space Res. 56, 1389-1399, DOI: 10.1016/j.asr.2015.07.006.

Schumann, W.O. (1952), On the free oscillation of a conducting sphere, which is surrounded by an air layer and an ionospheric shell, Z. Naturforsch. A 7, 2, 149-154, DOI: 10.1515/zna-1952-0202 (in German).

Sentman, D.D. (1996), Schumann resonance spectra in a two-scale-height Earth-ionosphere cavity, J. Geophys. Res. 101, D5, 9479-9487, DOI: 10.1029/95JD03301.

Turman, B.N. (1978), Analysis of lightning data from DMSP satellite, J. Geophys. Res.-Oceans 83, NC10, 5019-5024, DOI: 10.1029/JC083iC10p05019. 
Twardosz, R. (2010), A synoptic analysis of the diurnal cycle of thunderstorm precipitation in Kraków (Southern Poland), Int. J. Climatol. 30, 7, 1008-1013, DOI: 10.1002/joc.1960.

Zięba, S., and Z. Nieckarz (2014), Sunspot Time Series: Passive and Active Intervals, Solar Phys. 289, 7, 2705-2726, DOI: 10.1007/s11207-014-0498-6.

\section{ZASTOSOWANIE METODY DEKOMPOZYCJI WIDMA REZONANSU SCHUMANNA W CELU ANALIZY TLUMIENIA WNĘI ZIEMIA-JONOSFERA}

\section{Streszczenie}

Celem pracy jest wyznaczenie thumienia $(\chi)$ wnęki rezonansowej Ziemia-jonosfera $(Z-j)$ na podstawie częstotliwości własnej pierwszego modu rezonansowego $\left(f_{1}\right)$ wyznaczonej z widm mocy sygnału ekstremalnie niskiej częstotliwości ELF (ang. Extremely Low Frequency), metodą dekompozycji (Kułak i in. 2006), a zmierzonego z wykorzystaniem stacji pomiarowych o diametralnie różnej budowie.

W pracy wykorzystano wyniki pomiarów, które wykonano magnetycznymi antenami horyzontalnymi (NS i EW) pracującymi w stacji ELF Hylaty (SE Polska, 22.5 ${ }^{\circ} \mathrm{E}, 49.1^{\circ} \mathrm{N}$ ) oraz stacji ELF Yon (kanton Yongsheng, prowincja Yunan w Chinach, $100.8^{\circ} \mathrm{E}, 26.7^{\circ} \mathrm{N}$ ). Okres pomiaru obejmuje 9 dób (2011.05.31 - 2011.06.09). Stacje odległe są od siebie o 6980 km i różnią się znacząco zarówno konstrukcją jak i charakterystyką toru pomiarowego.

W niniejszej pracy wykazano, że analizując wyniki pomiarów ELF wykonanych dwiema różnymi stacjami pomiarowymi o różnych lokalizacjach na globie, metoda dekompozycji w pozwala wyznaczyć zgodną dla obu stacji średnią częstotliwość $\left(f_{1}\right)$ wnęki rezonansowej Z-j.

Badany okres przypada na fazę wzrostu w 24 cyklu słonecznym. Korzystając z obliczonej średniej wartości $f_{1}$ równej $7.93 \mathrm{~Hz}$ oraz wyników pracy (Kułak i in. 2006) wyznaczono dla tego okresu średnią wartość tłumienia wnęki Z-j, która wyniosła $\chi=3.43 \times 10^{-6} \Omega \mathrm{m}^{-1} \mathrm{~Hz}^{-1 / 2} \mathrm{i}$ jest zbliżona do zakresu tłumień uzyskanych inną metodą (Kułak i in. 2003) dla fazy wzrostu w 23. cyklu słonecznym. 



\title{
Studies on Annual Variations of African Storm Centre Using the Schumann Resonance Decomposition Method
}

\author{
Karol MARTYNSKI ${ }^{1, \bowtie}$, Andrzej KULAK ${ }^{1}$, and Janusz MLYNARCZYK ${ }^{1}$ \\ ${ }^{1}$ Department of Electronics AGH University of Science and Technology, Cracow, Poland \\ karol.martynski@agh.edu.pl
}

Many studies have been conducted on thunderstorm activity in recent decades, one of them was started by W.O. Schumann (1952). He discovered a resonance phenomenon associated with ELF (Extremely Low Frequencies) electromagnetic waves propagating around the Earth. The Schumann resonance (SR) can be observed at frequencies close to 8, 14, 20, $26 \mathrm{~Hz}$ (Balser and Wagner 1960). These frequencies are associated with the existence of the Earth-ionosphere cavity, in which the ELF waves are excited mainly by atmospheric discharges. In 1992, E. Williams from Massachusetts Institute of Technology (Williams 1992) noticed a strong correlation between the amplitude of the first Schumann resonance mode, and a mean subtropical temperature. In the following years many scientist tried to map storm centres located in South America, Africa and Asia (e.g. Heckman et al. 1998, Nickolaenko et al. 1998, Shvets 2001, Ando et al. 2005).

Our team in the last 15 years developed the decomposition method, which allows us to obtain pure resonance parameters such as: amplitude of each resonance mode, its frequency, asymmetry and width (Kułak et al. 2006). Using the decomposition method we are able to measure global activity in regard of space and time. The method allows to separate a symmetrical part of the power spectrum which can be used to infer the distance from the source and its intensity. We apply the method to localise storm centres and to measure the dipole moment of lightning discharges in 5-minute time intervals. Observations of the Schumann resonance are conducted in Poland since 1992, which enables the study of climatological changes throughout the years. Since 2005 our observations have been automated. To conduct the analysis, we used the data from the Hylaty ELF station, located in the eastern part of the Bieszczady Mountains in Poland (Kulak et al. 2014). The station is equipped with two antennas and one of them is directly pointed at the African continent.

In this work, we present preliminary results of our study to analyse the distribution and the intensity of the African storm centre (ASC). We have used the data from January to December, due to Intertropical Convergence Zone (ITCZ) movement, which influences the source. Our main goal was to analyse annual changes, which occur in ASC. So far only the most active months had been studied - January and August (Dyrda et al. 2014). Available tools allow us conduct more complex studies, which shows changes throughout the year. In the presented case 
we have chosen the data from 2015, because our new ELF station (ELA10) was already installed and well tested. Studies over ASC show that in NH winter the highest intensity of the African centre moves southward from the equator, and the opposite happens in the summer. In conclusion, position and intensity of the ASC is highly correlated with seasons in both hemispheres. Our studies show that its position might spread up to $20^{\circ}$ in both directions.

Analysis of annual movement of ASC leads to better and deeper understanding of the processes, occurring in these systems. Furthermore, we plan to study annual variations in other storm centres to compare them and to analyse differences between them.

Acknowledgments. This work was supported by the National Science Centre, Poland, under Grant 2015/19/B/ST9/01710.

References

Ando, Y., M. Hayakawa, A.V. Shvets, and P. Nickolaenko (2005), Finite difference analyses of Schumann resonance and reconstruction of lightning distribution, Radio Sci. 40, RS2002, DOI: 10.1029/2004RS003153.

Balser, M., and C.A. Wagner (1960), Observations of Earth-ionosphere cavity resonances, Nature 188, 638, DOI: $10.1038 / 188638 \mathrm{a} 0$.

Dyrda, M., A. Kulak, J. Mlynarczyk, M. Ostrowski, J. Kubisz, A. Michalec, and Z. Nieckarz (2014), Application of the Schumann resonance spectral decomposition in characterizing the main African thunderstorm center, J. Geophys. Res. 119, 13338-13349, DOI: 10.1002/2014JD022613.

Heckman, S.J., E. Williams, and B. Boldi (1998), Total global lightning inferred from Schumann resonance measurements, J. Geophys. Res. 103, D24, 31775-31779, DOI: 10.1029/98JD02648.

Kułak, A., J. Młynarczyk, S. Zięba, S. Micek, and Z. Nieckarz (2006), Studies of ELF propagation in the sphericall shell cavity using a field decomposition method based on asymmetry of Schumann resonance curves, J. Geophys. Res. 111, A10304, DOI: 10.1029/2005JA011429.

Kulak, A., J. Kubisz, S. Klucjasz, A. Michalec, J. Mlynarczyk, Z. Nieckarz, M. Ostrowski, and S. Zieba (2014), Extremely low frequency electromagnetic field measurements at the Hylaty station and methodology of signal analysis, Radio Sci. 49, 6, 361-370, DOI: 10.1002/2014RS005400.

Nickolaenko, A.P., G. Sàtori, B. Zieger, L.M. Rabinowicz, and I.G. Kudintseva (1998), Parameters of global thunderstorm activity deduced from the long-term Schumann resonance records, $J$. Atmos. Sol.-Terr. Phys. 60, 3, 387-399, DOI: 10.1016/S1364-6826(97)00121-1.

Schumann, W.O. (1952), On the free oscillations of a conducting sphere which is surrounded by an air layer and an ionosphere shell, Z. Naturforsch. A 7, 2, 149-154, DOI: 10.1515/zna-1952-0202 (in German).

Shvets, A.V. (2001), A technique of reconstruction of global lightning distance profile from background Schumann resonance signal, J. Atmos. Sol.-Terr. Phys. 63, 1061-1074, DOI: 10.1016/S13646826(01)00024-4.

Williams, E.R. (1992), The Schumann Resonance: a global tropical thermometer, Science 256, 5060, 1184-1188, DOI: 10.1126/science.256.5060.1184. 


\section{BADANIE ROCZNYCH ZMIAN AFRYKAŃSKIEGO CENTRUM BURZOWEGO PRZY UŻYCIU METODY DEKOMPOZYCJI REZONANSU SCHUMANNA}

\section{Streszczenie}

Wiele badań nad aktywnością burzową zostało przeprowadzonych w ostatnich dekadach, jedne z nich rozpoczął W.O. Schumann (1952). Przewidział teoretycznie, powiązane z falami elektromagnetycznymi ELF (Extremely Low Frequencies) propagującymi wokół Ziemi. Rezonans Schumanna (RS) obserwuje się przy częstotliwościach zbliżonych do 8, 14, 20, $26 \mathrm{~Hz}$ (Balser i Wagner 1960). Te częstotliwości są powiązane $\mathrm{z}$ istniejącą wnęką Ziemia-Jonosfera, w której fale ELF są wzbudzanie głównie przez wyładowania atmosferyczne. W 1992 roku E. Williams z Massachusetts Institute of Technology (Williams 1992) zauważył silną korelację pomiędzy amplitudą pierwszego modu RS, a średnią temperaturą w regionie subtropikalnym. W kolejnych latach wielu naukowców próbowało tworzyć mapy centrów burzowych, zlokalizowanych na kontynencie południowo-amerykańskim, afrykańskim oraz azjatyckim (Heckman i in. 1998, Nickolaenko i in. 1998, Shvets 2001, Ando i in. 2005). Nasz zespół w ostatnich 15 latach rozwinął metodę dekompozycji, która pozwala na otrzymanie czystych parametrów rezonansowych, takich jak: amplituda każdego piku rezonansowego, ich częstotliwość, asymetria czy szerokość (Kułak i in. 2006). Wykorzystując metodę dekompozycji jesteśmy w stanie mierzyć globalną aktywność burzową w ujęciu czasu i przestrzeni. Metoda pozwala na odseparowanie symetrycznej części widma mocy od reszty widma. Część symetryczna jest wykorzystywana do wyznaczania odległości pomiędzy stacją a źródłem oraz intensywności tych centrów. Metodę stosujemy do lokalizacji centrów burzowych i pomiaru momentu dipolowego wyładowań w pięciominutowych interwałach Obserwacje RS są prowadzone w Polsce od 1992 roku, umożliwia to badanie zmian klimatycznych. Od 2005 roku nasze obserwacje są zautomatyzowane. Aby przeprowadzić analizę, użyliśmy danych ze stacji Hylaty, zlokalizowanej we wschodniej części polskich Bieszczadów (Kulak i in. 2014). Stacja jest wyposażona $\mathrm{w}$ dwie ortogonalne anteny, jedna $\mathrm{z}$ nich ustawiona prostopadle do kontynentu afrykańskiego, co pozwala na bezpośredni odbiór sygnałów z tamtego kierunku.

$\mathrm{W}$ tej pracy prezentujemy wstępne wyniki naszych badań. W celu zanalizowania rozkładu przestrzennego i intensywności afrykańskiego centrum burzowego (ACB), wykorzystaliśmy dane od stycznia do grudnia 2015 roku. Badanie tego okresu ma za zadanie pokazać wpływ Międzyzwrotnikowej Strefy Konwergencji (ITCZ) na przemieszczanie się centrum burzowego. Naszym głównym celem była analiza zmian rocznych, które zachodzą w ACB. Jak dotąd jedynie miesiące o największej aktywności zostały przebadane - styczeń oraz sierpień (Dyrda i in. 2014). Dostępne narzędzia, pozwalają nam przeprowadzić bardziej skomplikowane badania, które pozwalają śledzić zmiany w ciągu roku. W prezentowanym przypadku wybraliśmy rok 2015, ponieważ nasza najnowsza stacja ELF (ELA10) była już zainstalowana i przetestowana. Badania nad ACB pokazują, że zimą największa aktywność centrum afrykańskiego znajduje się na południe od równika, natomiast sytuacja odwraca się podczas lata na półkuli północnej. Podsumowując, położenie i intensywność ACB jest silnie skorelowana z porami roku na obu półkulach. Nasze badania pokazują, że położenie centrum zmienia się w zasięgu $20^{\circ} \mathrm{W}$ obu kierunkach.

Roczna analiza ruchu ACB prowadzi do lepszego i głębszego zrozumienia procesów zachodzących w tym systemie. Pozwoli to na ocenę wpływu zmian klimatu jakie ma na centrum burzowe. Ponadto, planujemy przebadać roczne zmiany w pozostałych centrach burzowych, aby móc porównać je ze sobą i ocenić różnice między nimi. 



\title{
Winfried Otto Schumann - An Unfinished Biography
}

\author{
Andrzej KULAK ${ }^{1, \bowtie}$ \\ ${ }^{1}$ Department of Electronics AGH University of Science and Technology, Krakow, Poland \\ kulak@oa.uj.edu.pl
}

W.O. Schumann's (1888-1974) scientific biography is full of surprising episodes and ambiguities. Over the course of his life he changed his interests several times. Unexpectedly in 1952 he opened a new field of geophysical research: the studies of the propagation of Extremely Low Frequency (ELF) waves in the Earth-ionosphere cavity.

Winfried Schumann was born in Tübingen, and was a son of a physical chemist. His early years were spent in Kassel, and in Berndorf, a town near Vienna. After graduating from the Technological Institute in Karlsruhe (Karlsruher Institut für Technologie) in 1913 he obtained a doctorate in high voltage electrical engineering work: "Über die Drehmomente der Dämpferwicklung einer Mehrphasen-Synchronmaschine bei kleinen Pendelschwingungen im Parallelbetrieb" (On the torques of the damper winding of a multiphase synchronous machine at small pendulum oscillations in parallel operation). Then he got the position of the chief design engineer at the renowned company Brown Boveri. During the First World War he served as a radio operator. After the war in 1919 he worked as a research assistant of the Robert Bosch Foundation in the Institute of Electrical Engineering at the Technische Hochschule Stuttgart. In 1920 he qualified for university teaching (Habilitation) with a thesis on "Electrical breakdown stress of gases". In the same year he was nominated Associate Professor of Technical Physics at the University in Jena (Besser 2007). During this time he conducted theoretical and laboratory research on discharges in rarefied gases and their applications in technology. In 1923 he published the book "Elektrische Durchbruchfeldstärke von Gasen. Theoretische Grundlagen und Anwendung" (Electrical breakdown in gases. Theoretical principles and applications).

In 1924 he moved to the Technical University of Munich (Technische Universität München), and remains there until the end of his life. He holds a position of a full professor of physics and becomes the director of the Electrophysical Institute (Elektrophysikalisches Institut). For many years to come, he designs high-intensity discharge lamps and optimizes highcurrent high-speed switching systems. Between 1935 and 1938 he fills in 16 patents in this field in five countries, including England and the USA (Schumann, Google Patents), and publishes books on applied electrodynamics (Hoffmann et al. 1930, Schumann 1931). His publication activity stops between 1939 and 1945. It is not clear what Schumann did during the war. In the period of National Socialism, the Technical University of Munich, similarly to the University of Munich, has become an arena of strong political tension. Shortly after the end of the war, on 
July 26, 1945, Schumann was interrogated in Munich by the mixed US-British military committee CIOS (Combined Intelligence Objectives Sub-Committee). In the CIOS262 document, made available recently, one can find a description of the state of his research in the field of construction of carbonated lamps and switching systems at the Munich laboratory (Ramm and Mullett 1945). Schumann is positively verified and returns to work at the university. In an atmosphere of normalisation, in 1947, he became a member of the Bavarian Academy of Sciences. However, he is soon unexpectedly taken to the Wright-Patterson Air Force base in Ohio. His two-year stay in the USA is shrouded in mystery. In 1949 Schumann returns to Munich and once again takes the position of a professor of physics at the university, which he will keep until he withdraws from active research at the age of 75.

In 1952 he unexpectedly begins publishing a series of works on the Earth-ionosphere cavity (Schumann 1952a, b, c; 1954, 1956). The reason for this sudden change in interests is unknown. Is this related to the work carried out earlier during the war? Was his stay in Ohio related to the possibility of building a radio communication system in the ELF range, like the Goliath system which the Kriegsmarine implemented in 1943 in the VLF range? Anyway, in 1956 the US Navy immediately pays attention to a publication about the cavity and initiates the Pangloss project which aims to generate the Schumann resonances. Before the first transmission systems was developed, M. Balser and C.A. Wagner from MIT (Massachusetts Institute of Technology) discover in New Mexico the natural Schumann resonance fields (Balser and Wagner 1960). This is a breakthrough event that rapidly accelerates research on ELF waves. In 1962 a group of researchers from MIT arrives in Munich to discuss the results of resonance measurements with Schumann and his colleague H. König. In the same year, J. Galejs and J.R. Wait present a confidential report on the possibility of building a wave generation system in the ELF range. In 1963 Schumann returns to the United States at an invitation of the Pangloss group at MIT. The result of his stay is a study dedicated to the propagation of ELF waves in inhomogeneous magnetized plasma (Schumann 1964).

In 1968 the US Navy reveals that it carries out the Sanguine project, which aims at building a global communication system with submarines. This system, under the name SEAFARER (Surface ELF Antenna For Addressing Remotely Employed Receivers), reaches operational status at the frequency of $76 \mathrm{~Hz}$ only in 1987 (Barr et al. 2000). The history of the Schumann resonance research which follows is that the studies gradually migrate to civilian domain. Today, the study of the Earth-ionosphere cavity brings together dozens of people in many countries (Kulak 2019, this issue). However, the tormenting question still remains unanswered: what prompted W.O. Schumann to work on the Earth-ionosphere cavity in 1952 ?

Acknowledgments. This work was supported by the National Science Centre, Poland, under Grant 2015/19/B/ST9/01710.

References

Balser, M., and C.A. Wagner (1960), Observations of Earth-ionosphere cavity resonances, Nature 188, 638, DOI: $10.1038 / 188638 \mathrm{a} 0$.

Barr, R., D. Llanwyn Jones, and C.J. Rodger (2000), ELF and VLF radio waves, J. Atmos. Sol.-Terr. Phys. 62, 17-18, 1689-1718, DOI: 10.1016/S1364-6826(00)00121-8.

Besser, B.P. (2007), Synopsis of the historical development of Schumann resonances, Radio Sci. 42, RS2S02, DOI: 10.1029/2006RS003495.

Hoffmann, G., W. O. Schumann, W. Wien, and F. Harms (1930), Elektrostatik: Hockspannungstechnik, Akademische Verlagsgesellschaft. 
Kulak, A. (2019), Modern research on the Schumann Resonances, Publs. Inst. Geophys. Pol. Acad. Sc. 425 (M-32), 9-19 (this issue).

Ramm, E.T., and L.B. Mullett (1945), United States. Publication Board, Interrogation of Professor W.O. Schumann of the Electro-Physical Laboratory, Munchen Beiv, Washington, D.C., Office of the Publication Board, Dept. of Commerce.

Schumann, W.O., Google Patents, https://patents.google.com.

Schumann, W.O. (1923), Elektrische Durchbruchfeldstärke von Gasen. Theoretische Grundlagen und Anwendung, Springer, Berlin.

Schumann, W.O. (1931), Elektromagnetische Grundbegriffe: ihre Entwicklung und ihre einfachsten technischen Anwendungen, Oldenbourg, München und Berlin.

Schumann, W.O. (1952a), Über die strahlungslosen Eigenschwingungen einer leitenden Kugel, die von einer Luftschicht und einer Ionosphärenhülle umgeben ist, Z. Naturforsch. A 7, 2, 149-154, DOI: 10.1515/zna-1952-0202.

Schumann, W.O. (1952b), Über die Dämpfung der elektromagnetischen Eigenschwingnugen des Systems Erde-Luft-Ionosphäre, Z. Naturforsch. A 7, 3-4, 250-252, DOI: 10.1515/zna-1952-3-404.

Schumann, W.O. (1952c), Über die Ausbreitung sehr langer elektriseher Wellen um die Erde und Signale des Blitzes, Nuovo Cim. 9, 12, 1116-1138, DOI: 10.1007/BF02782924.

Schumann, W.O. (1956), Über die zeitliche Form und das Spektrum ausgesendeter Dipolsignale in Einer dielektrischen Hohlkugel mit leitenden Wänden, mit besonderer Anwendung auf atmosphärische Signale, Verlag der Bayerischen Akademie.

Schumann, W.O. (1964), The propagation of long electric waves in magnetized plasma and their passage through plasma layers, Defense Technical Information Center, Boston.

Schumann, W.O., and H. König (1954), Über die Beobactung von "atmospherics" bei geringsten Frequenzen, Naturwissensch. 41, 8, 183-184, DOI: 10.1007/BF00638174.

\section{WINFRIED OTTO SCHUMANN - NIEDOKOŃCZONA BIOGRAFIA}

\section{Streszczenie}

Biografia naukowa W.O. Schumanna (1888-1974) jest pełna zaskakujących zwrotów i niejasności. W ciągu życia kilkakrotnie zmieniał swoje zainteresowania. Nieoczekiwanie w 1952 roku zapoczątkował nowy kierunek badań geofizycznych: badania propagacji fal ELF we wnęce Ziemia-jonosfera.

W.O. Schumann przyszedł na świat w Tybindze jako syn fizykochemika. Wczesne lata spędził w Kassel oraz w Berndorf, mieście niedaleko Wiednia. Po ukończeniu Instytutu Technologicznego w Karlsruhe (Karlsruher Institut für Technologie) uzyskał w 1913 r. doktorat z elektrotechniki wysokich napięć (praca „Über die Drehmomente der Dämpferwicklung einer Mehrphasen-Synchronmaschine bei kleinen Pendelschwingungen im Parallelbetrieb"). Następnie objął stanowisko głównego inżyniera konstruktora w renomowanej firmie Brown Boveri. Podczas pierwszej wojny światowej pełnił funkcję operatora radiowego. Po $1919 \mathrm{r}$. rozpoczął pracę w charakterze asystenta badawczego Fundacji Roberta Boscha w Instytucie Elektrotechniki na Politechnice w Stuttgarcie. W 1920 r. zdobywa uprawnienia do nauczania uniwersyteckiego (habilitację) na podstawie rozprawy „Electrical breakdown stress of gases”. W tym samym roku zostaje mianowany profesorem nadzwyczajnym fizyki technicznej na Uniwersytecie w Jenie (Besser 2007). W tym czasie rozwija badania teoretyczne i laboratoryjne nad wyładowaniami w gazach rozrzedzonych i ich zastosowaniach w technice. W $1923 \mathrm{r}$. wydaje książkę „Elektrische Durchbruchfeldstärke von Gasen. Theoretische Grundlagen und 
Anwendung" (Przebicie elektryczne w gazach; zasady teoretyczne i zastosowania). W $1924 \mathrm{r}$. przenosi się na Uniwersytet Techniczny w Monachium (Technische Universität München), z którym wiąże się do końca życia. Obejmuje stanowisko profesora fizyki i zostaje dyrektorem Instytutu Elektrofizycznego (Elektrophysikalisches Institut). Przez wiele następnych lat zajmuje się projektowaniem lamp wyładowczych dużej mocy oraz optymalizacją wysokoprądowych układów przełączających o dużych szybkościach. W latach 1935-38 zgłasza 16 patentów z tej dziedziny w pięciu krajach, w tym w Anglii i USA (Schumann, Google Patents). Wydaje także książki poświęcone elektrodynamice stosowanej (Hoffmann et al. 1930, Schumann 1931).

Jego działalność publikacyjna zamiera w latach 1939 do 1945. Nie jest jasne, czym zajmował się Schumann w czasie drugiej wojny. W okresie narodowego socjalizmu Uniwersytet Techniczny w Monachium, podobnie jak Uniwersytet Monachijski, stał się areną silnych napięć politycznych. Tuż po zakończeniu wojny, 26 lipca 1945 r., Schumann został przesłuchany w Monachium przez mieszaną amerykańsko-brytyjską komisję wojskową CIOS (Combined Intelligence Objectives Sub-Committee). W od niedawna dostępnym dokumencie CIOS262, można znaleźć opis stanu jego badań w dziedzinie konstrukcji gazowanych lamp i układów przełączających prowadzonych w laboratorium w Monachium (Ramm i Mullett 1945). Schumann zostaje pozytywnie zweryfikowany i powraca do pracy na uniwersytecie. W atmosferze normalizacji, w 1947 r., zostaje członkiem Bawarskiej Akademii Nauk. Jednak wkrótce zostaje nieoczekiwanie przewieziony do bazy Wright-Patterson Sił Powietrznych Stanów Zjednoczonych w Ohio. Jego dwuletni pobyt w USA jest owiany tajemnicą. W 1949 r. Schumann wraca do Monachium i ponownie obejmuje stanowisko profesora fizyki na uniwersytecie, które będzie kontynuował aż do wycofania się z aktywnych badań w wieku 75 lat.

W 1952 r. nieoczekiwanie rozpoczyna publikację serii prac o wnęce Ziemia-jonosfera (Schumann 1952a, b, c; 1954, 1956). Przyczyny tej nagłej zmiany zainteresowań nie są znane. Czy mają one związek z pracami prowadzonymi wcześniej w czasie wojny? Czy pobyt w Ohio dotyczył dyskusji nad możliwością budowy systemu łączności radiowej w zakresie ELF, na wzór zrealizowanego w 1943 r. przez Kriegsmarine systemu Goliath, pracującego w zakresie VLF? Tak, czy inaczej, w 1956 r. Marynarka Wojenna Stanów Zjednoczonych natychmiast zwraca uwagę na publikacje o wnęce i inicjuje projekt Pangloss, którego celem jest generacja rezonansu Schumanna. Nim opracowano pierwsze układy nadawcze, w 1960 r. M. Balser i C. A. Wagner z MIT (Massachusetts Institute of Technology) dokonują w Nowym Meksyku odkrycia naturalnego pola rezonansu Schumanna (Balser i Wagner 1960). Jest to przełomowe wydarzenie, które gwałtownie przyspiesza badania fal ELF. W 1962 r. do Monachium przybywa grupa badaczy z MIT, by przedyskutować z Schumannem i jego współpracownikiem H. Königiem wyniki pomiarów rezonansu. W tym samym roku J. Galejs i J.R. Wait przedstawiają poufny raport o możliwości budowy systemu do generacji fal w zakresie ELF. W 1963 r. Schumann wyjeżdża ponownie do Stanów Zjednoczonych na zaproszenie grupy Pangloss w MIT. Rezultatem jego pobytu jest praca poświęcona propagacji fal ELF w niejednorodnej namagnesowanej plazmie (Schumann 1964).

W 1968 r. marynarka amerykańska ujawnia, że prowadzi projekt Sanguine, którego celem jest budowa globalnego systemu łączności z łodziami podwodnymi. System ten pod nazwą SEAFARER (Surface ELF Antenna For Addressing Remotely Employed Receivers) osiąga stan operacyjny na częstotliwości $76 \mathrm{~Hz}$ dopiero w 1987 r. (Barr i in. 2000). Dalsza historia badań rezonansu Schumanna rozszerza się stopniowo na badania cywilne. Dzisiaj badania wnęki Ziemia-jonosfera skupiają dziesiątki osób w wielu krajach (Kulak 2019, niniejsze wydanie). Jednak ciągle bez odpowiedzi pozostaje pytanie, co skłoniło Schumanna do pracy nad wnęką Ziemia-jonosfera w 1952 r.? 


\title{
Observational systems, mathematical and numerical methods, modelling
}

\author{
Systemy pomiarowe, \\ metody matematyczne i numeryczne \\ oraz modelowanie
}





\title{
Schumann Resonance Monitoring in Hornsund (Spitsbergen) and Suwałki (Poland)
}

\author{
Mariusz NESKA ${ }^{1, \bigotimes}$, Paweł CZUBAK ${ }^{1}$, and Jan REDA ${ }^{1}$ \\ ${ }^{1}$ Institute of Geophysics, Polish Academy of Sciences, Warsaw, Poland \\ $\triangle$ nemar@igf.edu.pl
}

\section{INTRODUCTION}

Schumann resonances are resonances of electromagnetic waves in the Earth-ionosphere cavity, and were first predicted and discussed by W.O. Schumann (1952). They are excited by worldwide thunderstorm activity. Maximal amplitudes (modes) can be observed at around $8 \mathrm{~Hz}, 14$ $\mathrm{Hz}, 21 \mathrm{~Hz}$, and so on. Monitoring of Schumann resonances provides information about properties of the lower ionosphere, world thunderstorm activity, and global climatic change.

\section{LOCATIONS AND SITE DESCRIPTION}

Locations of Schumann resonance stations maintained by IG PAS are shown in Fig. 1. First Schumann resonance observations by IG PAS were initiated at the Polish Polar Station Hornsund (Spitsbergen) in 2004. This was an outcome of a joined Polish-Hungarian NATO project (2003-2005, EST.CLG.980431). The Hornsund experience led to development of a second set of instruments which was installed in Belsk Observatory (Poland) in 2005. In 2016 this apparatus has been moved to a National Park close to Suwałki because of a significant increase of artificial disturbances in Belsk. The Suwałki station works to date. Basic information about these three stations is listed in Table 1.

\section{APPARATUS}

Monitoring of Schumann resonances in our three sites is performed by means of induction coil magnetometers and electric ball antennas. Induction magnetometers are used for measurements of the magnetic horizontal components, and the electric antenna (Fig. 2) measures the vertical electric component.

The magnetometer consists of two induction coils, one per horizontal component, and an electronic console for amplification and filtration. Examples of system responses for a magnetic component are shown in Fig. 3.

All apparatus for SR observations was constructed and developed in Central Geophysical Observatory at Belsk in the early 2000s. Measurement of electric component ceased to be continued for Hornsund in 2013 and for Belsk in 2016. 
Table 1

Description of three SR sites (Belsk, Hornsund, and Suwałki)

\begin{tabular}{|c|c|c|c|}
\hline & Belsk & Hornsund & Suwałki \\
\hline Station code & BEL & HRN & SUW \\
\hline Latitude $[\mathrm{deg}]$ & $51.835 \mathrm{~N}$ & $77.000 \mathrm{~N}$ & $54.012 \mathrm{~N}$ \\
\hline Longitude $[\mathrm{deg}]$ & $20.789 \mathrm{E}$ & $15.550 \mathrm{E}$ & $23.183 \mathrm{E}$ \\
\hline Elevation $[\mathrm{m}]$ & 173 & 15 & 150 \\
\hline Start date & $2005-02-21$ & $2004-09-11$ & $2016-06-19$ \\
\hline End date & $2016-05-03$ & --- & --- \\
\hline Components & $\mathrm{Bx}, \mathrm{By}, \mathrm{Ez}$ & $\mathrm{Bx}, \mathrm{By}$ & $\mathrm{Bx}, \mathrm{By}$ \\
\hline
\end{tabular}

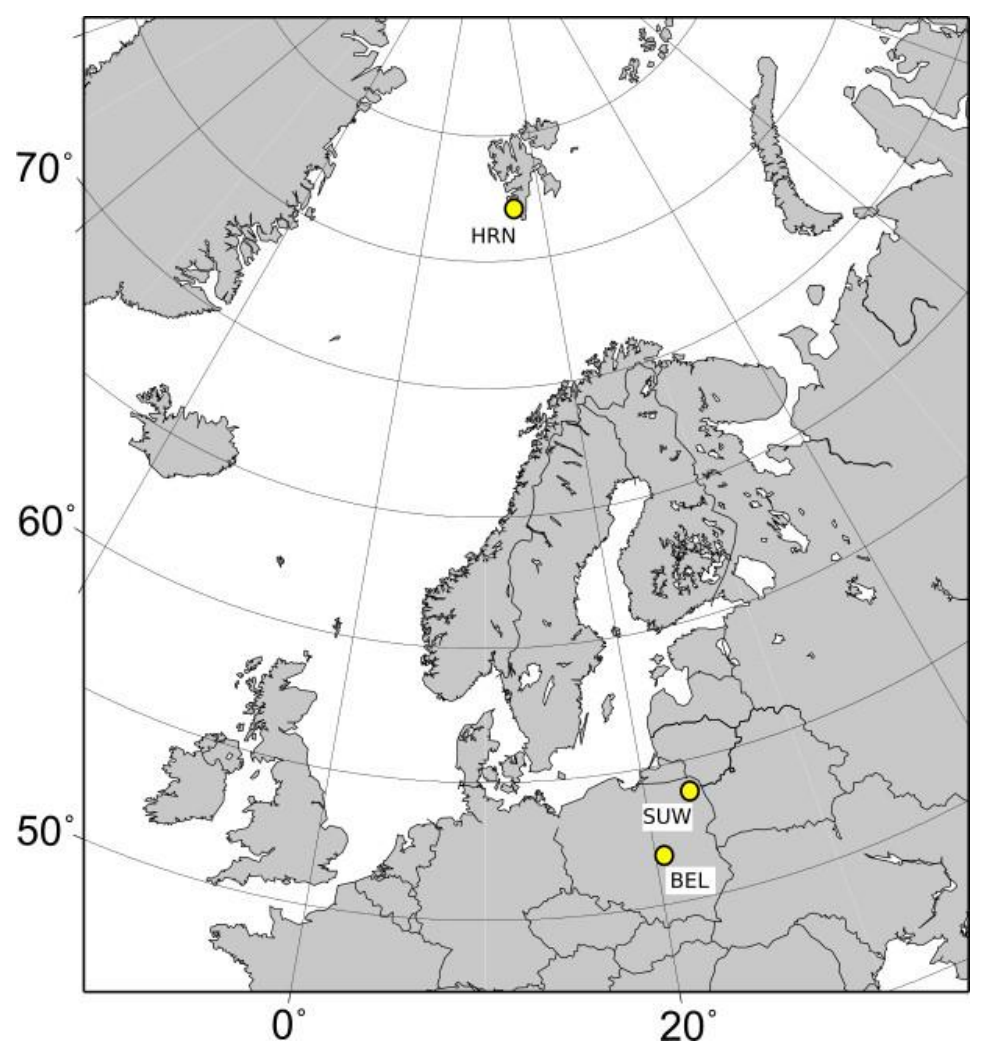

Fig. 1. Locations of SR stations.

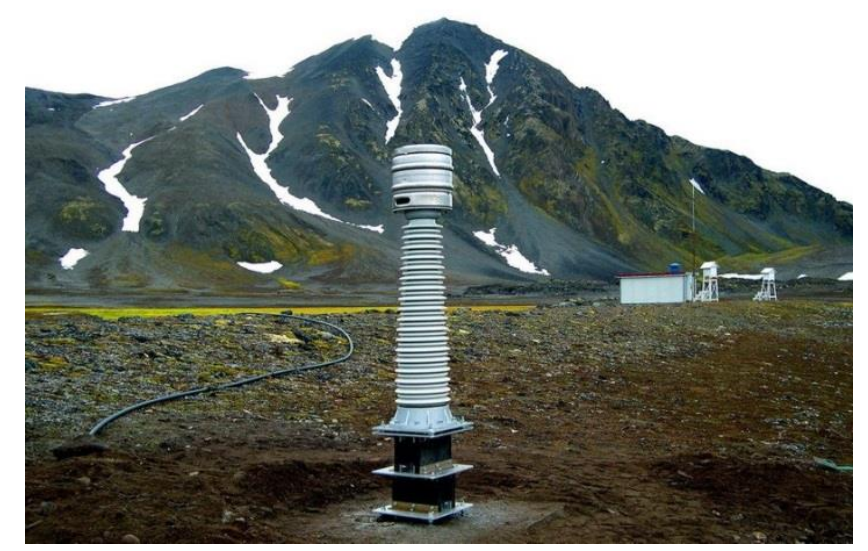

Fig. 2. Electric antenna in Hornsund. 


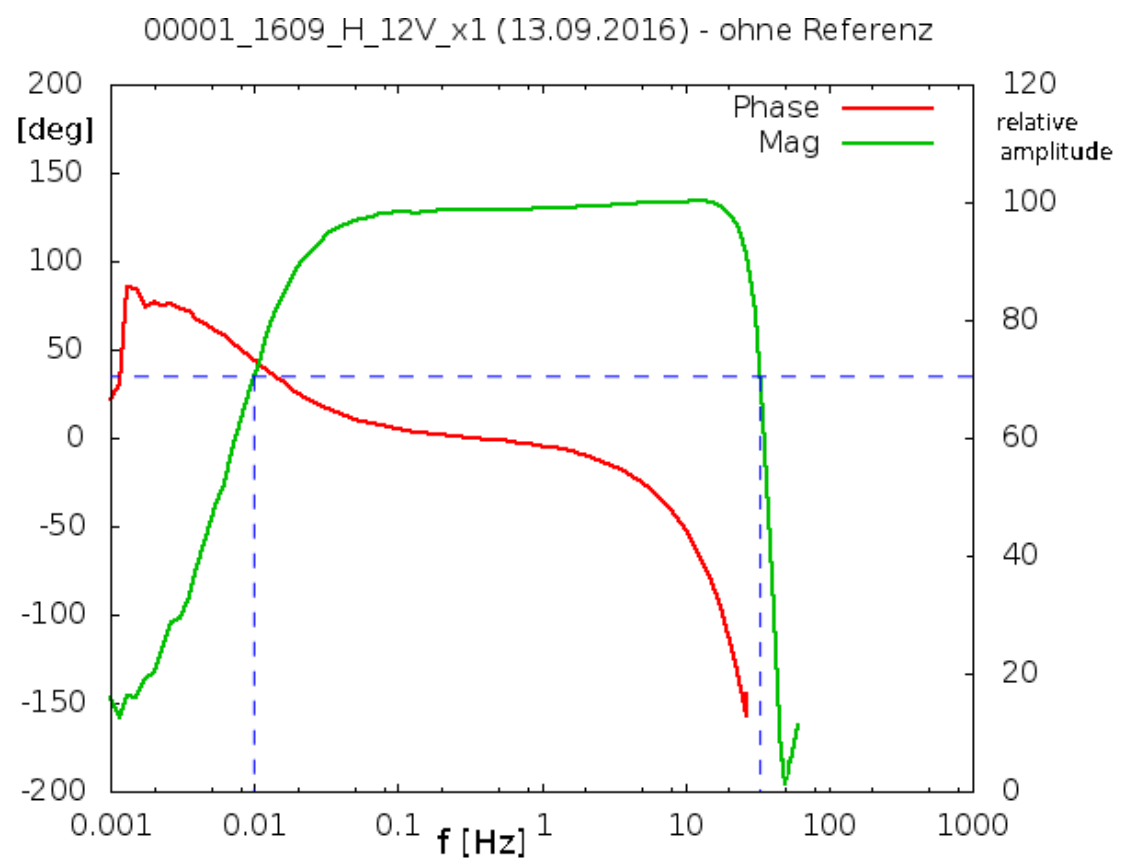

Fig. 3. System response for Bx component (HRN).

The sampling frequency is $100 \mathrm{~Hz}$ for all stations. For recording we use a 24-bit NDL data logger equipped with GPS module and Ethernet interface. The NDL logger has been developed in IG PAS, too.

\section{DATA TRANSFER AND QUALITY CONTROL}

Data from all three stations are automatically transferred (every 5 minutes) via Internet (VPN connection) to IG PAS servers located in Belsk and Warsaw. Then (also automatically) raw data are converted to daily DDF files. Binary DDF format is used for geomagnetic and magnetotelluric data in our institute. We have a lot of tools for edition, visualization, filtration, rotation and other operations on data in DDF format. Every day we check spectrograms for SR stations on our internal web pages. Examples of power spectra are shown in Fig. 4.
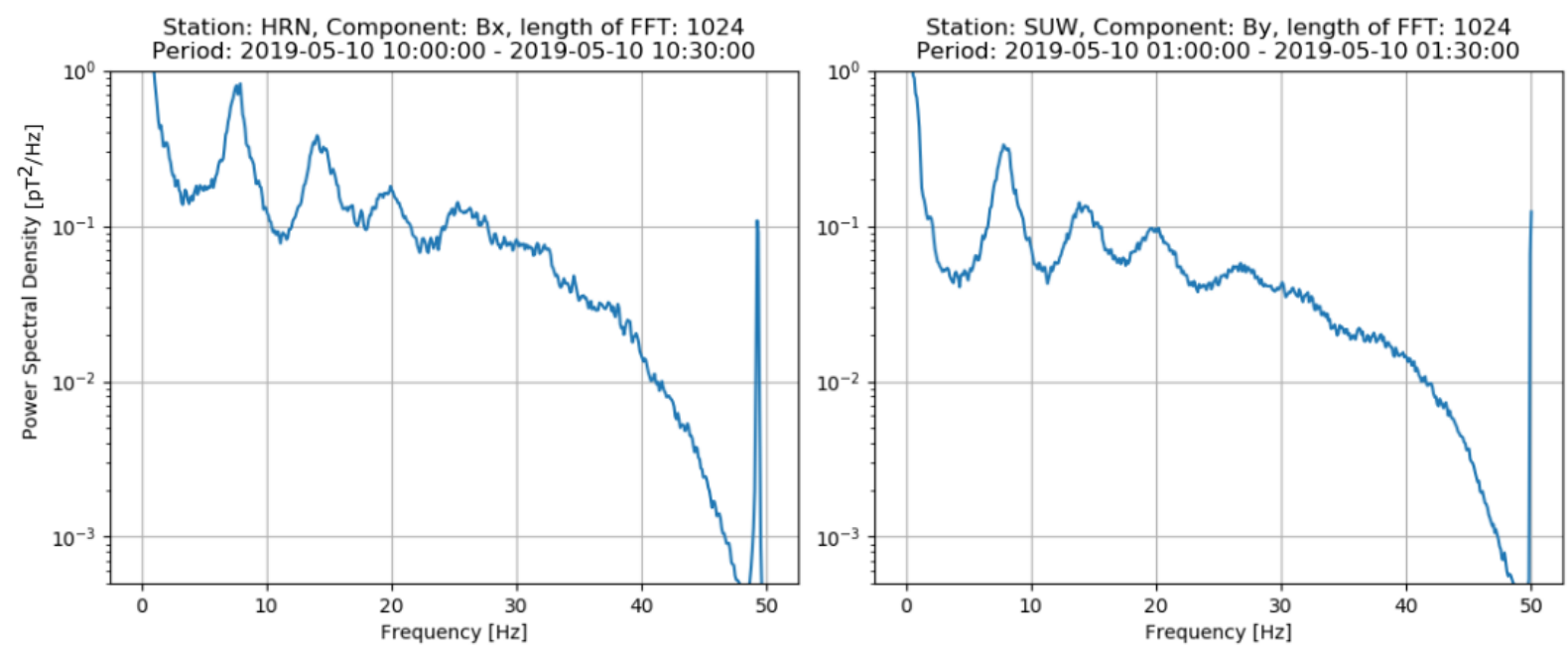

Fig. 4. Example power spectra for Hornsund and Suwałki. 


\section{USAGE OF SCHUMANN RESONANCE DATA FROM IG PAS STATIONS}

First observations of the Schumann resonance phenomenon in Belsk and Hornsund were described by Neska and Sátori (2006). Various applications including data from our Schumann resonance stations can be found in Neska (2007), Sátori et al. (2007), Sátori et al. (2012), Nickolaenko et al. (2014), and Williams et al. (2014).

Acknowledgments. This work is supported by the Ministry of Science and Higher Education of Poland for the statutory activities of the Institute of Geophysics, Polish Academy of Sciences, grant No. 3841/E-41/S/2019, and SPUB.

\section{References}

Neska, A. (2007), On the use of fast registrations of observatories as a reference for magnetotelluric measurements. In: „XII IAGA Workshop on Geomagnetic Observatory Instruments, Data Acquisition and Processing", Publs. Inst. Geophys. Pol. Acad. Sc. C-99 (398), 315-322.

Neska, M., and G. Sátori (2006), Obserwacje rezonansu Schumanna w Polskiej Stacji Polarnej na Spitsbergenie oraz Obserwatorium Geofizycznym w Belsku, Prz. Geof. 51, 3-4, 189-198.

Nickolaenko, A.P., A.Yu. Schekotov, M. Hayakawa, Y. Hobara, G. Sátori, J. Bor, and M. Neska (2014), Multi-point detection of the elf transient caused by the gamma flare of December 27, 2004, Radiophys. Quantum El. 57, 2, 125-140, DOI: 10.1007/s11141-014-9498-5.

Sátori, G., M. Neska, E. Williams, and J. Szendröi (2007), Signatures of the day-night asymmetry of the Earth-ionosphere cavity in high time resolution Schumann resonance records, Radio Sci. 42, RS2S10, DOI: 10.1029/2006RS003483.

Sátori, G., V. Mushtak, M. Neska, T. Nagy, and V. Barta (2012), Global lightning dynamics deduced from Schumann resonance frequency variations at two sites $\sim 550 \mathrm{~km}$ apart, European Geophysical Union General Assembly 2012, Geophys. Res. Abstr. 14, EGU2012-10647.

Schumann, W.O. (1952), Über die strahlungslosen Eigenschwingungen einer leitenden Kugel, die von einer Luftschicht und einer Ionosphärenhülle umgeben ist, Z. Naturforsch. A 7, 2, 149-154, DOI: 10.1515/zna-1952-0202.

Williams, E., R. Boldi, V. Mushtak, J. Bor, G. Satori, Y. Hobara, T. Nagy, A. Sinha, M. Sato, M. Neska, A. Koloskov, Y. Yampolski, R. Moore, M. Mitchell, and A.C. Fraser-Smith (2014), Inversion of multi-station Schumann resonance background records for global lightning activity in absolute units, AGU Fall Meeting 2014, AE24A-08. 


\title{
OBSERWACJE REZONANSU SCHUMANNA W HORNSUNDZIE (SPITSBERGEN) I W SUWALKACH (POLSKA)
}

\author{
Streszczenie
}

Rezonans Schumanna jest to zjawisko rezonansowe fal częstotliwości ELF propagujących się $\mathrm{w}$ naturalnej wnęce rezonansowej uformowanej między powierzchnią Ziemi a dolną jonosferą. Źródłem rezonansu Schumanna jest globalna aktywność burzowa. Pierwsze obserwacje zjawiska rezonansu Schumanna w IGF PAN rozpoczęto w roku 2004 w Polskiej Stacji Polarnej w Hornsundzie w ramach wspólnego, polsko-węgierskiego projektu NATO (20032005, EST.CLG.980431). Doświadczenia z Hornsundu zaowocowały wykonaniem drugiego zestawu aparatury, który został zainstalowany w 2005 r. w obserwatorium w Belsku. Z powodu znacznego wzrostu sztu-cznych zakłóceń w paśmie ELF w roku 2016 zdecydowano się przenieść aparaturę z Belska do stacji w Suwałkach, która znajduje się na terenie Wigierskiego Parku Narodowego. Aparatura do obserwacji zjawiska rezonansu Schumanna została w całości opracowana i wykonana w IGF PAN. Składa się ona z magnetometru indukcyjnego mierzącego składowe poziome ziemskiego pola magnetycznego oraz anteny elektrycznej do pomiaru składowej pionowej pola ele-ktrycznego. Dane pomiarowe z Belska, Hornsundu i Suwałk wykorzystywane są w licznych pracach naukowych dotyczących m.in. badania zmian klimatycznych na Ziemi, wyznaczaniu parametrów dolnej jonosfery oraz obserwacji globalnej aktywności burzowej. 



\title{
First Results From a New Broadband ELF Measurement System
}

\author{
Janusz MLYNARCZYK ${ }^{1, \bigotimes}$ \\ Andrzej KULAK ${ }^{1}$, Slawomir KLUCJASZ ${ }^{1}$, Jerzy KUBISZ ${ }^{2}$, and Adam MICHALEC ${ }^{2}$ \\ ${ }^{1}$ AGH University of Science and Technology, Department of Electronics, Krakow, Poland \\ ${ }^{2}$ Astronomical Observatory, Jagiellonian University, Krakow, Poland \\ $\bowtie$ januszm@agh.edu.pl
}

We have built a new broadband ELF (extremely low frequency) measurement system (Mlynarczyk et al. 2018). It enables us to study atmospheric discharges, in particular those associated with Transient Luminous Events (Pasko 2010, Bór 2013 and references therein), with high temporal resolution. It also allows us to study other natural phenomena in the ELF range and to conduct research on radio wave propagation. The system is composed of two active magnetic antennas and a receiver, and measures the magnetic field component of electromagnetic waves in the ELF range. In the last couple of months we have optimized the most important parts of the system and achieved a significant improvement of its performance. Our active antennas have a bandwidth of $20 \mathrm{mHz}$ to $1 \mathrm{kHz}$. The receiver uses a Bessel anti-aliasing filter, which has an attenuation of above $35 \mathrm{~dB}$ at the Nyquist frequency and an energy bandwidth of $900 \mathrm{~Hz}$. The sampling frequency has been set to $3.0 \mathrm{kHz}$. Its high accuracy has been achieved through GPS synchronization of local oscillator every hour and use of temperature compensated oscillator. The use of a Bessel filter enables us to measure atmospheric discharges without distortions typical for other types of anti-aliasing filters. The data are stored on Compact Flash memory cards. The system is powered from a $12 \mathrm{~V}$ battery and its current consumption depends on the model of memory card, ranging from 57 to $83 \mathrm{~mA}$. The use of battery power and a careful choice of location allows us to perform measurements without a $50-\mathrm{Hz}$ notch filter and use digital filtering in software when processing the data. For the new system, we have also optimized the conversion factor of the analog part, to limit the influence of ADC (analog-to-digital converter) noise near the Nyquist frequency on the current moment waveform reconstructed using our inverse method (Kulak and Mlynarczyk 2011, Mlynarczyk et al. 2015). Since the conversion factor determines the maximum amplitude level, its choice is an uneasy trade-off which has to take into account the future location of the measurement station. Typically, we set the maximum amplitude between 28 and $40 \mathrm{nT}$ peak to peak, but in some cases we use higher or lower levels. The minimum discernible signal is determined by the 18-bit ADC. Since the

C 2019 Institute of Geophysics, Polish Academy of Sciences 
equipment works outdoor, the antennas have been placed in waterproofed pipes and the receiver in a water-proofed container.

In this work we report on the first results from our newly optimized ELF system. The first continuous observations after optimizations have been carried out simultaneously at two locations: at the Hylaty ELF station (Kulak et al. 2014) in the Bieszczady Mountains, and at an external measurement field of Laboratoire Souterrain à Bas Bruit in France.

Acknowledgments. This work has been supported by the National Science Centre, Poland, under Grant 2015/19/B/ST10/01055.

\section{References}

Bór, J. (2013), Optically perceptible characteristics of sprites observed in Central Europe in 2007-2009, J. Atmos. Sol.-Terr. Phys. 92, 151-177, DOI: 10.1016/j.jastp.2012.10.008.

Kulak, A., and J. Mlynarczyk (2011), A new technique for reconstruction of the current moment waveform related to a gigantic jet from the magnetic field component recorded by an ELF station, Radio Sci. 46, RS2016, DOI: 10.1029/2010RS004475.

Kulak, A., J. Kubisz, S. Klucjasz, A. Michalec, J. Mlynarczyk, Z. Nieckarz, M. Ostrowski, and S. Zieba (2014), Extremely low frequency electromagnetic field measurements at the Hylaty station and methodology of signal analysis, Radio Sci. 49, 6, 361-370, DOI: 10.1002/2014RS005400.

Mlynarczyk, J., J. Bór, A. Kulak, M. Popek, and J. Kubisz (2015), An unusual sequence of sprites followed by a secondary TLE: An analysis of ELF radio measurements and optical observations, J. Geophys. Res. - Space 120, 2241-2254, DOI: 10.1002/2014JA020780.

Mlynarczyk, J., A. Kulak, S. Klucjasz, J. Kubisz, K. Martynski, and M. Popek (2018), New broadband ELF receiver for studying atmospheric discharges in Central Europe, 2018 Baltic URSI Symposium, Poznan, Polska.

Pasko, V. (2010), Recent advances in theory of transient luminous events, J. Geophys. Res. 115, A00E09, 1-24, DOI: 10.1029/2009JA014860.

\section{PIERWSZE WYNIKI Z NOWEGO SZEROKOPASMOWEGO SYSTEMU POMIAROWEGO ELF}

\section{Streszczenie}

Nasz zespół zaprojektował nowy szerokopasmowy system pomiarowy ELF (extremely low frequency) (Mlynarczyk et al. 2018), w celu prowadzenia badań wyładowań atmosferycznych związanych z Transient Luminous Events (Pasko 2010, Bór 2013 i referencje tam zawarte) na terenie Europy. System składa się z dwóch aktywnych anten magnetycznych i odbiornika, umożliwiających pomiar składowej magnetycznej fal elektromagnetycznych w zakresie ELF (extremely low frequency). W ciągu ostatnich kilku miesięcy zoptymalizowaliśmy najważniejsze komponenty systemu, osiągając znaczącą poprawę parametrów. Anteny aktywne obejmują pasmo pomiarowe od $20 \mathrm{mHz}$ do $1 \mathrm{kHz}$. Odbiornik wykorzystuje filtr antyaliasingowy o charakterystyce typu Bessela, który ma tłumienie ponad $35 \mathrm{~dB}$ na częstotliwości Nyquista i pasmo energetyczne $900 \mathrm{~Hz}$. Częstotliwość próbkowania nowego odbiornika wynosi 
$3.0 \mathrm{kHz}$. Wykorzystanie filtru Bessela pozwala na pomiary wyładowań atmosferycznych bez zniekształceń typowych dla innych typów filtrów antyaliasingowych. Zoptymalizowaliśmy także współczynnik konwersji części analogowej systemu, aby ograniczyć wpływ szumu przetwornika analogowo-cyfrowego w pobliżu częstotliwości Nyquista na zrekonstruowany przebieg momentu prądowego otrzymywany poprzez rozwiązania odwrotne (Kulak i Mlynarczyk 2011, Mlynarczyk i in. 2015). W związku z tym, że współczynnik konwersji determinuje maksymalną rejestrowaną amplitudę, jego wybór jest niełatwym kompromisem, który musi uwzględniać również przyszłą lokalizację stacji pomiarowej. W związku z tym, że aparatura pracuje w warunkach polowych, anteny zostały umieszczone w hermetycznych rurach, a odbiornik w hermetycznym kontenerze.

$\mathrm{W}$ tej pracy przedstawiamy nasze pierwsze wyniki z nowego zoptymalizowanego systemu ELF. Pierwsze ciągłe obserwacje są obecnie prowadzone symultanicznie w dwóch lokalizacjach: na stacji Hylaty (Kulak i in. 2014) w Bieszczadach, oraz na zewnętrznym polu pomiarowym Laboratoire Souterrain à Bas Bruit we Francji. 



\title{
A Few Glances on Fractional Calculus from the Geophysical-ELF Point of View
}

\author{
Piotr KOPERSKI ${ }^{1, \bowtie}$ \\ ${ }^{1}$ Association Astronomia Nova, Poland \\ $\triangle$ pkopersk@wit.edu.pl
}

\section{INTRODUCTION}

Since about the last 30 years one can notice an increasing interest in the so called "calculus of fractional order" (also known under different names, as e.g. "fractional calculus" or "fractional differ-integrals"). Using the opportunity of an open formula of this meeting, I would like to bring this topic a bit closer and to present some ideas potentially applicable in the domain of our interest. Because the topic is extensive, this presentation is a brief introduction, accompanied with a few examples and bibliography.

The topic is not new. In the oral presentation, I will remind of a few "milestones" set by great scientists. Here is the one: in the letter to Leibniz from 1695, L'Hospital asked him about its notation $d^{n} f(x) / d x^{n}$ : what it would mean, if $n=1 / 2$ ? Leibniz responded that it is an apparent paradox, from which one day useful consequences will be drawn.

As a friendly introduction, let us take a look at the $n$-th order derivative of a function $f(t)$ defined over a range: $a \leq t \leq x$. It can be written as:

$$
\frac{d^{n} f(x)}{d x^{n}}=\lim _{h \rightarrow 0} \frac{1}{h^{n}} \sum_{k=0}^{[(x-a) / h]}(-1)^{k}\left(\begin{array}{l}
n \\
k
\end{array}\right) f(x-k h)
$$

where: $a \leq x, n, k, p \geq 0,\left(\begin{array}{l}n \\ k\end{array}\right)=\frac{n !}{k ! \cdot(n-k) !}$ is Newton symbol, $[x]$ is integer part of $x$ and the property: $\left(\begin{array}{l}p \\ q\end{array}\right)=0$ for $q>p$ is used (all necessary details will be discussed in the presentation).

Playing with some algebra (e.g. Podlubny 1999) one can show that the $n$-th order integral $(n>0)$ of $f(t)$ in the range $a \leq t \leq x$ can be expressed in a very similar way:

$$
I^{n} f(x) \equiv \int d t_{1} \ldots \int d t_{n} f\left(t_{n}\right)=\lim _{h \rightarrow 0} \frac{1}{h^{-n}} \sum_{k=0}^{[(x-a) / h]}(-1)^{k}\left(\begin{array}{c}
-n \\
k
\end{array}\right) f(x-k h)
$$


Looking this way, one has array of similar operators labeled (and defined) with the natural $n$, comprising both integration (for $n<0$ ) and differentiation (for $n>0$ ) - therefore the term "differ-integrals":

$$
\ldots D^{-n} \equiv I^{n}, \ldots D^{-1} \equiv I^{1}, D^{0} \equiv \text { Identity }, D^{1}, \ldots D^{n}, \ldots
$$

One of possible ways of looking at, ,what it means the integration or differentiation of fractional order" is to observe, that the definitions above can be extended (made continuous) using the Euler Gamma function, $\Gamma(n)$, as $n !=\Gamma(n+1)$. Indeed, as another ,historical milestone" can be regarded the approach of L. Euler (1730), who applied similar idea in a specific case of $f(x)=x$ and $n=1 / 2$ to get:

$$
\frac{d^{1 / 2} x}{d x^{1 / 2}}=\frac{2}{\sqrt{\pi}} x^{1 / 2}
$$

Of special importance is that the above formulas are principally nonlocal - even derivative (Eq. 2) require function $f()$ to be considered over an interval. This is the generic feature of „fractional calculus”. This should not be very surprising, as e.g. the well known „Cauchy integral formula" expresses (,normal”) derivatives by integral - for sufficiently regular functions on complex plane:

$$
f^{(n)}(z)=\frac{n !}{2 \pi i} \int_{C} \frac{f(t)}{(t-z)^{n+1}} d t
$$

The difference, for a non integer value $\alpha$, is that a branch cut appears instead of a pole. To highlight the nonlocality, fractional operators are named using upper- and lower boudaries (respectively $a$ and $x$ ) like this: ${ }_{a} D^{\alpha}{ }_{x} f(x)$

There is no unique definition of a fractional order derivative or integral, and several approaches can be distinguished. This can be seen as a weakness but it reflects a deep nature of that idea and is also encouraging for new research. Three most popular definitions will be shortly described in oral presentation.

\section{DEFINITIONS AND DETAILS}

As a few notes and clarifications will be needed, I will start recalling necessary properties of the Newton symbol, Euler Gamma and other mathematic stuff.

In the rest of this Section I will present definitions, list some properties - and compare three most popular types of ,fractionals” - those of:

- Grünwald-Letnikov,

- Riemann-Liouville,

- Caputo.

\section{TRAPS, DIFFICULTIES AND REWARDS}

Using a few examples I will point out (some) traps and difficulties usually met with ,differintegrals", as:

- what happens with a constant and monomial,

- why exponential function is not comfortable choice,

- what about Leibniz rule. 
Fortunately, there is also a set of rewards here, some of which will also be listed. Two worth mention at this point are:

- two useful, universal kinds of special functions (Mittag-Leffler and Wright),

- profits when dealing with the power-law dependencies, especially in the domain of Fourier/Laplace transforms.

\section{SOME EXAMPLES AND INTERPRETATIONS}

Physical interpretations of „fractional calculus” is still under development, though there exist already some important achievements. The same is with discovering connections to several domains of science and applications. I will try to review some of such connections, interpretations and applications in parallel to a few examples. In this context, I will briefly talk about a few known applications, as:

- differential equations of a wave- and diffusion type,

- spectral analysis,

- some connection to fractals and stochasticity.

\section{POSSIBLE APPLICATIONS TO GEOPHYSICAL ELF INVESTIGATIONS}

Some ideas of „fractional calculus" will be discussed here in the context of the geophysical ELF. To the authors knowledge, there is only a very few contemporary works touching this domain, rather in a mathematical way. A few selected physical and mathematical aspects will be presented in a hope to create a starting point to improve spectral fitting and interpretation of results.

\section{References}

In this extended abstract I can only sketch the content so I refer only to one source. More general- and specific bibliography will be put in oral presentation and in its printed version in the workshop communications.

Podlubny, I. (1999), Fractional Differential Equations, Ser. Mathematics in Science and Engineering, Vol. 198, Academic Press, San Diego.

\section{KILKA SPOJRZEŃ NA RACHUNEK FRAKCJALNY Z PUNKTU WIDZENIA GEOFIZYCZNYCH BADAŃ ELF}

\section{Streszczenie}

W ciągu ostatnich około 30 lat daję się zauważyć rosnące zainteresowanie tzw. "rachunkiem różniczkowo-całkowym rzędu ułamkowego" (znanym też pod nieco innymi nazwami). Korzystając $\mathrm{z}$ otwartej formuły niniejszego spotkania, chciałbym przybliżyć nieco ten temat oraz przedstawić kilka własnych pomysłów potencjalnie interesujących $\mathrm{w}$ naszej dziedzinie. Ponieważ zagadnienie jest obszerne, w czasie wystąpienia zaprezentuję ogólne wprowadzenie wraz z kilkoma znanymi przykładami i podstawowa bibliografią. 
Zagadnienie nie jest nowe i w wystąpieniu wspomnę o kilku "kamieniach milowych" ustanowionych przez wielkich uczonych. Jako pierwszy można wymienić list L'Hospitala do Leibniza z 1695 roku, dotyczący notacji $d^{n} f(x) / d x^{n}$, w którym pyta on, jakie byłoby jej znaczenie $\mathrm{w}$ przypadku $n=1 / 2$ ? Leibniz odpowiedział, że jest to wyraźny paradoks, $\mathrm{z}$ którego pewnego dnia zostaną wyciągnięte użyteczne wnioski.

Nie istnieje jedna obowiązująca definicja całki - bądź pochodnej rzędu ułamkowego. Może to być postrzegane jako słabość, ale jest odzwierciedleniem złożoności zagadnienia i zachęca do dalszych badań. W trakcie wystąpienia przedstawię najczęściej spotykane podejścia wraz ze znanymi przykładami i podstawową interpretacją. Na początku przypomnę kilku niezbędnych pojęć i spróbuję wyjaśnić kilka oczywistych wątpliwości. Jedną z nich może być nielokalność, będąca zasadniczą cechą „operatorów frakcjalnych”: nawet pochodna funkcji jest rozpatrywana (i wyrażana) w formie całki po makroskopowym zakresie argumentu (równanie (1)). Nie powinno to jednak bardzo dziwić, skoro np. znany „wzór całkowy Cauchy’ego” też wyraża pochodną jako całkę po konturze (w płaszczyźnie zespolonej, dla odpowiednio regularnej funkcji). Następnie przedstawię i krótko porównam trzy definicje ,frakcjalnych całkopochodnych": Grünwalda-Letnikova, Riemann'a-Liouville'a oraz Caputo.

W oparciu o kilka prostych przykładów zwrócę uwagę na kilka trudności i pułapek, typowych w zetknięciu z „operatorami frakcjalnymi”, takich jak : co dzieje się ze stałą i z funkcja potęgową; dlaczego funkcja wykładnicza nie jest wygodna; co z regułą Leibniza? Pojawi się też zestaw nagród, z których wspomnę dwie: wygodne, uniwersalne klasy funkcji specjalnych (Mittag-Leffler'a i Wright'a) oraz wygoda w pracy z zależnościami typu potęgowego, zwłaszcza w dziedzinie transformacji Fouriera/Laplace’a.

Interpretacja „rachunku frakcjalnego” jest nadal w fazie rozwoju, choć dokonano kilku ważnych osiągnięć. To samo dotyczy związków z innymi dziedzinami badań i aplikacji. Przedstawię kilka zastosowań i interpretacji w oparciu o znane przykłady, m. in: równania różniczkowe typu dyfuzji i falowego; analizę widmową; związki z fraktalami i losowoscią.

$\mathrm{Na}$ koniec, kilka pojęć z „rachunku frakcjalnego” zostanie przedstawionych w kontekście geofizyki i ELF. Według wiedzy autora jest zaledwie kilka współczesnych prac dotykających tej dziedziny, zresztą głównie od strony matematycznej. Kilka wybranych aspektów fizycznych i matematycznych zostanie zaprezentowane $\mathrm{z}$ nadzieją, że posłużą jako punkt wyjścia dla poprawy dopasowania widmowego i interpretacji wyników obserwacji. 


\section{ELF, LF and HF remote sensing}

Teledetekcja w pasmie ELF, LF i HF 



\title{
ELF Remote Sensing of the Lower lonosphere using Group Velocity of Electromagnetic Radiation from Atmospheric Lightning Discharges
}

\author{
Marek GOŁKOWSKI ${ }^{1, \otimes}$, \\ Andrzej KUŁAK ${ }^{2,3}$, Janusz MŁYNARCZYK ${ }^{3}$, and Jerzy KUBISZ ${ }^{2}$ \\ ${ }^{1}$ Department of Electrical Engineering, University of Colorado Denver, Denver, USA \\ ${ }^{2}$ Astronomical Observatory, Jagiellonian University, Kraków, Poland \\ ${ }^{3}$ Department of Electronics, AGH University of Science and Technology, Kraków, Poland \\ $\triangle$ mark.golkowski@ucdenver.edu
}

\section{INTRODUCTION}

The lowest region of the upper atmosphere plasma environment is the ionospheric D-region, which exists in the altitude range of 65-95 km. D-region electron densities are maximum during the daytime and significantly reduced at night, but the plasma state persists at these altitudes at all hours and dominates the propagation and reflection of electromagnetic waves with frequencies below $100 \mathrm{kHz}$ and the absorption of MF (Medium Frequency: $300 \mathrm{kHz}-3 \mathrm{MHz}$ ) and HF (High Frequency: $3 \mathrm{MHz}-30 \mathrm{MHz}$ ) waves. The D-region is affected by magnetosphere-ionosphere coupling since energetic electron precipitation from the Earth's radiation belts and solar flare X-ray fluxes increase D-region ionization levels. Therefore monitoring the D-region electron is an important part of space weather monitoring.

Despite its recognized importance, the D-region electron density profile is challenging to diagnose as electron densities are too low for direct sounding and the altitude is too low for spacecraft observations. Rocket measurements provide the only direct observations and it should be noted that global ionospheric models like the International Reference Ionosphere do not provide validated electron density information below $100 \mathrm{~km}$. We present a novel way to perform D-region remote sensing using observations of lightning induced radiation in the ELF (Extremely Low Frequency: 3-300 Hz) band. In contrast to past work using lightning radiation, which relied on amplitude and phase changes over a broad spectrum, we use a single simple parameter of ELF group velocity to obtain the characteristics of the Earth-ionosphere propagation channel. Theoretical analysis and numerical modeling shows that the ELF group velocity can serve as a diagnostic for day-night conditions as well as changes induced by solar flares. 


\section{ELF PROPAGATION IN EARTH-IONOSPHERE WAVEGUIDE}

The D-region electron density profile is traditionally modeled using a two-parameter model first introduced in the 1960s. In this model the two key parameters are the reference height $h$ ' $[\mathrm{km}]$ and the steepness parameter $\beta\left[\mathrm{km}^{-1}\right]$ as shown below:

$$
N(z)=1.43 \times 10^{13} \exp \left[(\beta-0.15) z-\beta h^{\prime}\right]\left[\mathrm{m}^{-3}\right]
$$

There is a general consensus on the reference height diurnal dependence with $h^{\prime}<80 \mathrm{~km}$ during daytime with a minimum at local noon and $h^{\prime} \geq 80 \mathrm{~km}$ during the nighttime. There is less consensus on the steepness parameter $\beta$ with daytime ranges of $0.25-0.9 \mathrm{~km}^{-1}$ and nighttime ranges $0.25-2.8 \mathrm{~km}^{-1}$ reported in the literature. For waves in the Earth-ionosphere waveguide with frequencies below $400 \mathrm{~Hz}$, the group velocity can be significantly less than the speed of light and is affected by the D-region electron density profile. This unique dispersion, which is not present at higher frequencies, is due to the fact that the electric and magnetic fields of the ELF waves do not reach the same maximum altitude. The ionosphere strongly affects the coupling between the fields and the magnetic field can penetrate up to $100 \mathrm{~km}$ altitude while the electric field is confined to lower altitudes (Gołkowski et al. 2018).

\section{ELF OBSERVATIONS AND NUMERICAL MODELING}

Observations are made using ELF receivers in Hugo, Colorado, USA and Hylaty, Poland that are part of the World ELF Radiolocation Array (WERA) (Kulak et al. 2014). Global lightning
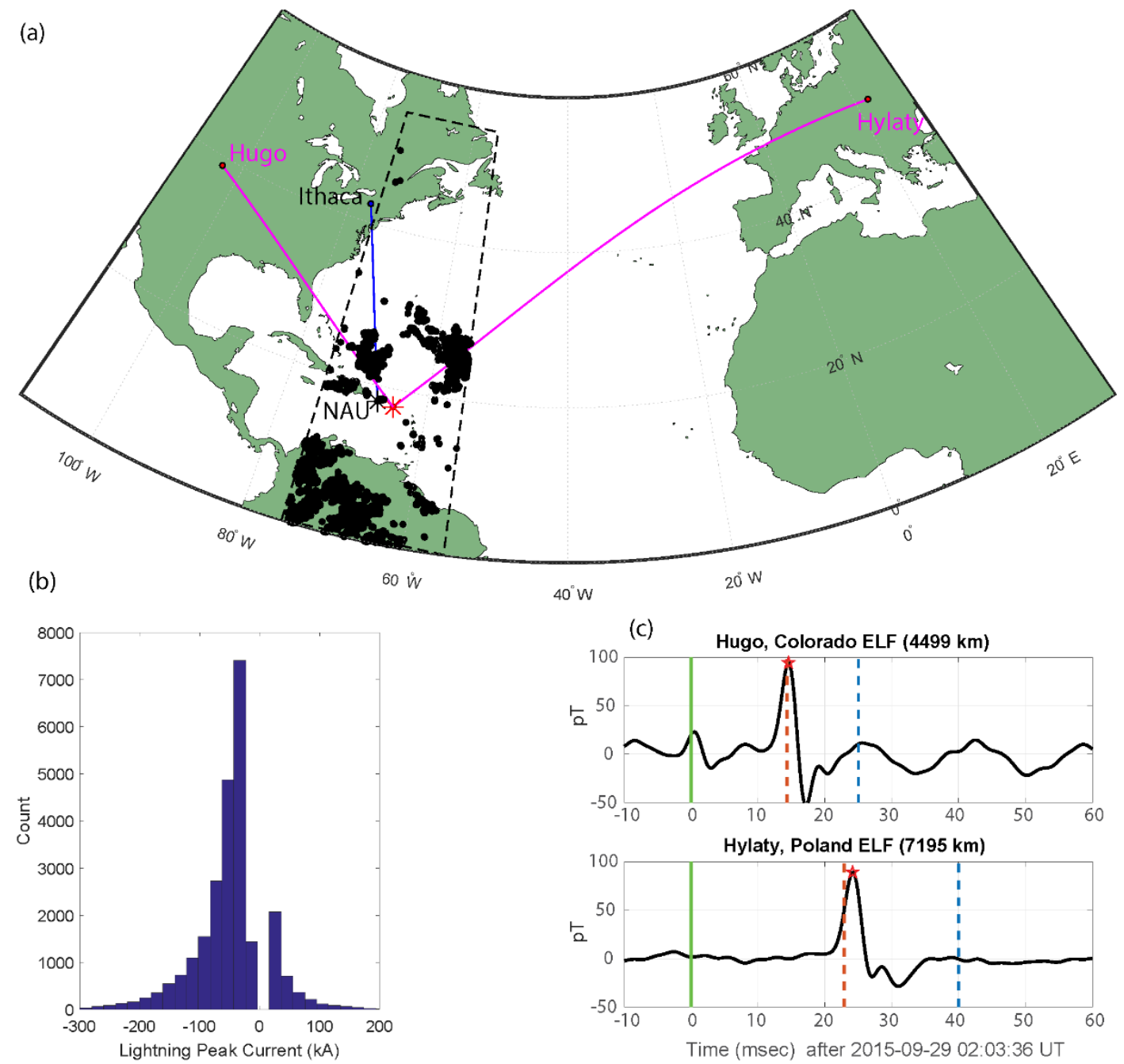
ning occurrence (timing and location) are obtained from the Global Lightning Dataset (GLD360) from Vaisala. The GLD360 network detects only cloud-to-ground (CG) discharges which produce a vertical dipole moment (Said et al. 2010). Figure 1 shows an observation scenario from 29 September 2015 where lightning along the North American Atlantic coast is observed with ELF receivers in Colorado and Poland. Only CG lightning discharges with peak currents above $10 \mathrm{kA}$ were used in the analysis since high peak currents of CG return strokes are associated with significant ELF radiation. Panel (b) shows a histogram of the peak current from 20,000 lightning discharges that were identified by the GLD360 network and also observed in the ELF data. The time domain data in panel (c) of Figure 1 shows the ELF waveforms, the peaks of which are used to obtain group velocity.

For numerical modeling we use the Long Wave Propagation Capability (LWPC) numerical model, which provides a modal solution to wave propagation in the Earth-ionosphere waveguide. Amplitude and phase at each frequency from LWPC is transformed into the time domain using the inverse Fourier transform.

\section{RESULTS}

Group velocity observations were made on 29 September 2015. Figure 2 shows results of group velocity observed at Hugo, Colorado and Hylaty, Poland from lightning along the North American east coast. The data are shown for the entire day and are averaged from approximately 20,000 lightning discharges occurring within the region of interest. The effect of the day-night transition is clearly seen in the propagation velocity, which increases when the propagation path is on the nightside and decreases for the dayside.

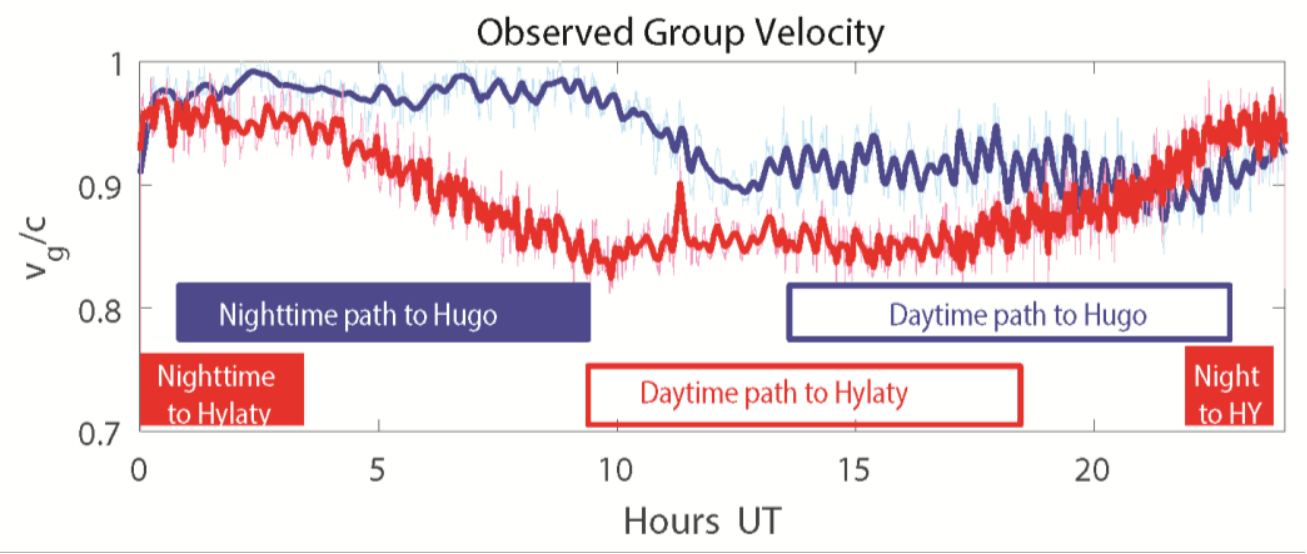

Fig. 2. Group velocity, $v_{g}$, as a fraction of the speed of light, $c$, from observations at Hugo, Colorado and Hylaty, Poland from North American lightning shown in Figure 1. The light traces are 20-point median filtered raw data, and dark traces are additional smoothed using a 100-point moving average. The group velocity increases for nighttime conditions and decreases for daytime conditions.

Figure 3 shows the ELF wave group velocity predicted by the LWPC simulation for different values of $h^{\prime}$ and $\beta$ parameters along the path from the Caribbean (near Puerto Rico) to Hugo, Colorado and Hylaty, Poland. The velocity values fall in the range of $0.85 c-0.95 c$,

Fig. 1. (a) Map showing receiver locations in Hugo, Colorado and Hylaty, Poland and CG lightning event locations observed on 29 September 2015 (black dots), and propagation paths are used in numerical modeling (pink). (b) Histogram of lightning peak current from GLD360 network. (c) Example of ELF waveforms from a single lightning discharge from which group velocity is extracted. Figure adapted from Gołkowski et al. (2018). 

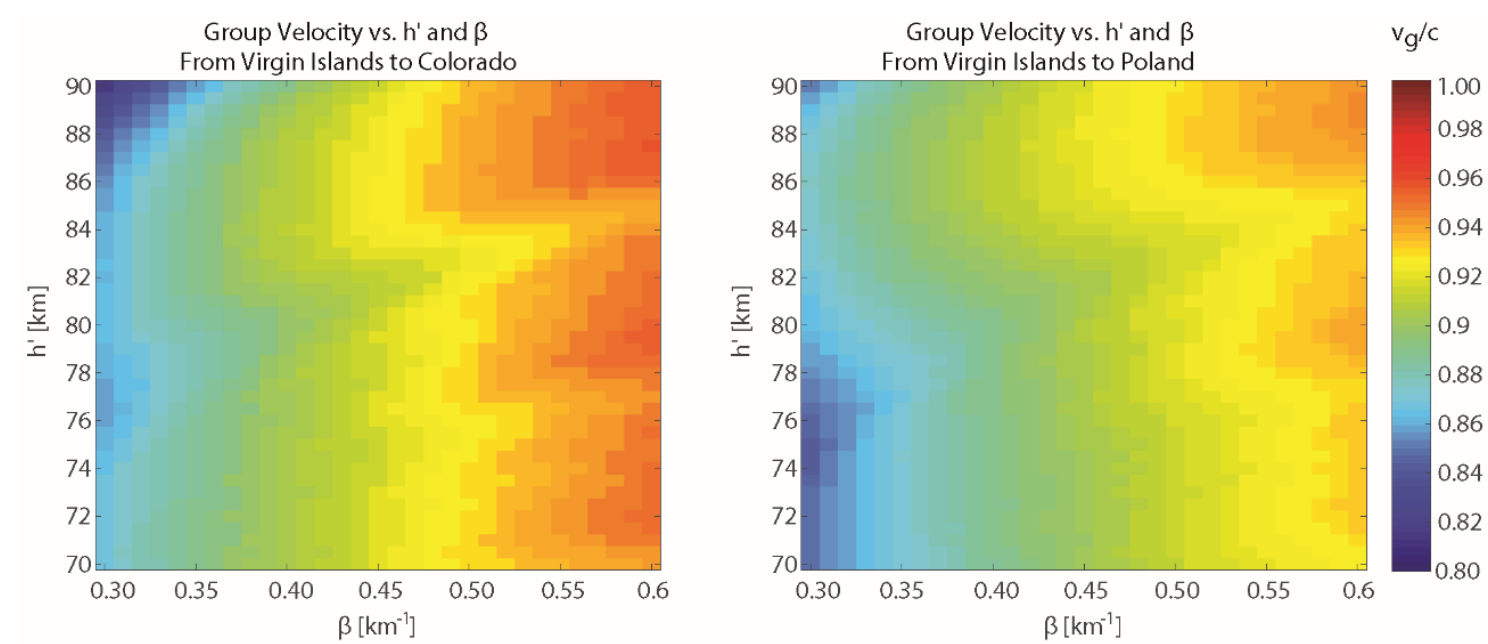

Fig. 3. ELF wave group velocity predicted from LWPC simulation for propagation paths to Hugo (left) and to Hylaty (right) illustrated in Fig. 1 for different combinations of $h^{\prime}$ and $\beta$.

where $\mathrm{c}$ is the speed of light in agreement with observations in Figure 2. The values for the Hugo path are at times slightly higher than for the Hylaty path. In both cases the group velocity shows a strong $\beta$ dependence and much weaker dependence on h' suggesting that ELF group velocity observations can be an effective way to diagnose the steepness of the D-region ionospheric profile.

\section{SUMMARY}

We have shown that the group velocity of lightning radiation in the ELF band can be used as a diagnostic of the D-region ionosphere. This new technique provides unique access to the $\beta$ value (steepness) of the two parameter D-region ionospheric model. The $\beta$ parameter has been difficult to quantify using other techniques. The group velocity technique can also be used to diagnose the D-region during solar flares. Using this technique a small number of ELF receivers and lightning detection data can provide a global D-region diagnostic.

Acknowledgments. This work was supported by the National Science Foundation (USA) with awards AGS 1451210 and AGS 1254365 to the University of Colorado Denver and by the National Science Center, Poland, under Grant 2012/04/M/ST10/00565.

\section{References}

Gołkowski, M., S.R. Sarker, C. Renick, R.C. Moore, M.B. Cohen, A. Kułak, J. Mlynarczyk, and J. Kubisz (2018), Ionospheric D region remote sensing using ELF sferic group velocity, Geophys. Res. Lett. 45, 23, 12739-12748, DOI: 10.1029/2018GL080108.

Kulak, A., J. Kubisz, S. Klucjasz, A. Michalec, J. Mlynarczyk, Z. Nieckarz, and S. Zieba (2014), Extremely low frequency electromagnetic field measurements at the Hylaty station and methodology of signal analysis, Radio Sci. 49, 6, 361-370, DOI: 10.1002/2014RS005400.

Said, R.K., U.S. Inan, and K.L. Cummins (2010), Long-range lightning geolocation using a VLF radio atmospheric waveform bank, J. Geophys. Res. 115, D23108, DOI: 10.1029/2010JD013863. 


\title{
TELEDETEKCJA NAJNIŻSZEJ WARSTWY JONOSFERY PRZY POMOCY PRĘDKOŚCI GRUPOWEJ PROMIENIOWANIA ELEKTROMAGNETYCZNEGO ELF OD WYLADOWAŃ ATMOSFERYCZNYCH
}

\author{
Streszczenie
}

Najniżej położona warstwa jonosfery to warstwa D na wysokości $65-95 \mathrm{~km}$. Koncentracja elektronów osiąga maksimum w ciągu dnia i znacznie spada w nocy, ale materia $\mathrm{w}$ stanie plazmy utrzymuje się na tych wysokościach całą dobę. Plazma w tej warstwie ma dominujący wpływ na propagację i odbijanie się fal radiowych z częstotliwościami poniżej $100 \mathrm{kHz}$ i absorbcje fal w pasmach MF (Medium Frequency - częstotliwości średnie) i HF (High Frequency - wysokie częstotliwości). Warstwa D wyraźnie odczuwa efekty sprzężenia jonosfera-magnetosfera, skoro wysyp energetycznych elektronów z pasm radiacyjnych i rozbłyski słoneczne znacznie zmieniają koncentracje elektronów w tej warstwie. Dlatego monitorowanie stanu warstwy D jest ważnym elementem monitorowania pogody kosmicznej.

Mimo kluczowej roli warstwy D w różnych zjawiskach, bezpośredni pomiar koncentracji plazmy w tej warstwie jest możliwy jedynie w trakcie drogich eksperymentów rakietowych, gdyż jej wysokość jest zbyt niska, by posłużyć się pomiarami satelitarnymi, a koncentracja elektronów jest za mała na pomiar jonosondami. Teledetekcja $\mathrm{z}$ falami $\mathrm{w}$ pasmie ELF (Extremely Low Frequency - krańcowo niskie częstotliwości) i VLF (Very Low Frequency bardzo niskie częstotliwości) pozostaje, jako jedyna metoda pozwalająca na monitorowanie warstwy D długotrwale na szerokim obszarze.

Prezentujemy tu nowy sposób teledetekcji przy pomocy prędkości grupowej fal elektromagnetycznych pochodzących $\mathrm{z}$ wyładowań atmosferycznych doziemnych w pasmie ELF. W odróżnieniu od poprzednich prac o podobnym charakterze, gdzie monitorowanie amplitudy i fazy na szerokim pasmie było konieczne, obecne podejście bazuje na pojedynczym parametrze, który jest stosunkowo łatwo dostępny.

Propagacja fal w falowodzie ziemia-jonosfera w częstotliwościach poniżej $400 \mathrm{~Hz}$ zachodzi w warunkach mocnej dyspersji, która nie istnieje podczas propagacji przy wyższych częstotliwościach. Owa dyspersja powoduje, że prędkość grupowa odzwierciedla profil koncentracji elektronowej warstwy D, szczególnie tzw. „stromość” profilu która wyraża się parametrem $\beta \mathrm{w}$ klasycznym dwuparametrowym modelu tej warstwy. Informacja $\mathrm{o}$ występowaniu i lokalizacji wyładowań atmosferycznych pochodzi z sieci GLD360, a fale ELF są obserwowane za przy pomocy stacji odbiorczych sieci WERA w Kolorado USA i w Polsce. Opisane tu obserwacje i symulacje z użyciem programu LWPC dowodzą, że metoda ta nadaje się do określenia zmian warstwy $\mathrm{D} w$ warunkach dzień-noc oraz w czasie perturbacji w wyniku rozbłysku słonecznego. Metoda pozwala na globalne monitorowanie warstwy D używając wyłącznie sieci WERA i GLD360. 



\title{
ELF Exploration of Mars
}

\author{
J. KOZAKIEWICZ1, \\ ${ }^{1}$ Jagiellonian University, Astronomical Observatory, Krakow, Poland \\ $\triangle$ j.kozakiewicz@uj.edu.pl
}

\section{INTRODUCTION}

Recently, due to a start of extensive space exploration, studies on propagation of electromagnetic waves in other bodies in the Solar System have become an important issue. In Martian exploration especially useful can be waves in extremely low frequency (ELF, $3 \mathrm{~Hz}-3 \mathrm{kHz}$ ) range. Attenuation of these waves in the Martian environment is very low, and they can propagate around the globe in a cavity, made of two high-conductivity spherical layers: the ionosphere and the ground. On Mars, as there is no liquid water at the planetary surface, the highconductivity layers of the ground are located in the subsurface. Therefore, ELF waves can propagate to the depth of many kilometers. In the Martian atmosphere, ELF waves can be generated by dust events, such as dust storms and dust devils, which are important factors influencing global atmospheric circulation. If ELF sources occur on Mars, an ELF station can be used as a tool to investigate not only the properties of the ionosphere, but also atmosphere, and the subsurface of Mars.

\section{THE IMPORTANCE OF MARS ELF EXPLORATION}

Even if ELF exploration of Mars can be related to many issues, e.g., daily dynamics of the ionosphere or global circuit existence, in this work, I will focus only on two goals of this exploration: measurements of ELF sources, and detection of underground liquid water.

\subsection{ELF sources on Mars}

The first goal of any Mars ELF exploration will be detection of ELF sources. Electrical discharges in the atmosphere of Mars can be related to triboelectric processes, associated with aeolian transport of sediments.

On the basis of ground-based telescopic data, which have been acquiring over more than 100 years, it has been found that global dust storms on Mars occur every few years (Martin and Zurek 1993), regional every few weeks, and local every day (Cantor et al. 2001). Local storms last a day, regional several days, global many weeks.

Martian dust devils can reach more than $10 \mathrm{~km}$ in height and a kilometer in diameter, whereas on Earth they are not higher than $2.5 \mathrm{~km}$ and not wider than $150 \mathrm{~m}$ (Fisher et al. 2005,

(C) 2019 Institute of Geophysics, Polish Academy of Sciences 
Greeley et al. 2006). Dust devils are present in all latitudes and elevations. They tend to occur during local spring and summer, with a peak in midsummer (Cantor et al. 2006).

Characteristics of discharges related with dust events are still unknown, although many experimental (Eden and Vonnegut 1973, Qu et al. 2004, Forward et al. 2009, Aplin et al. 2012), numerical (Kok and Renno 2009), and field test studies (Freier 1960, Stow 1969, Farrell et al. 2004) have been dedicated to investigate phenomena of electricity generate by aeolian transport.

On Earth, Stow (1969) observed upward-pointing electric fields up to $200 \mathrm{kV} / \mathrm{m}$ at the ground level during dust storms in the Sahara desert. The electric and magnetic observation of terrestrial dust devils have indicated presence of quasi-static DC electric fields of the order of 1-100 kV/m (Freier 1960, Farrell et al. 2004), AC currents, and ELF emission (Houser et al. 2003).

Observations of electrical discharges in the Martian atmosphere are also non-conclusive. In 2006, Ruf et al. (2009) conducted some research in the microwave range using a $34 \mathrm{~m}$ parabolic antenna of the Deep Space Network. They observed unusual pattern of radiation, emitted in minutes-long bursts, when a regional dust storm was present on Mars. Anderson et al. (2012) performed similar observation using the Allen Telescope Array in 2010. They found similar variations. However, this variability spread across a broad spectrum and was driven by narrowband radio frequency interferences. Gurnett et al. (2010) stated that during five-year search with the MARSIS (Mars Advanced Radar for Subsurface and Ionosphere Sounding) instrument, working on board Mars Express mission, no radio signals associated with discharges was discovered although during this period two major and several regional storms occurred.

ELF measurements from the planetary surface can easily resolve this issue, as even weak sources should be possible to detect from large distances (Kozakiewicz et al. 2016). It is highly probable that discharge intensity on Mars is weaker than on Earth, and also subjected to seasonal variations related to dust activity. Therefore, measurements of ELF source can be used also to improve Martian global atmospheric circulations models, which must include influence of dust on the atmosphere dynamics.

\subsection{Underground water}

The second important goal of ELF studies on Mars is to create an instrument capable of detecting subsurface layers rich in liquid water, a crucial issue in the search for life.

Certainly, underground water exploration can be conducted using seismic waves or radar frequencies, but these techniques have some disadvantages. Mars seismic activity is believed to be very low, as Mars is a geologically inactive planet. First marsquake, detected by the Seismic Experiment for Interior Structure (SEIS) instrument on Insight lander in April 2019, was very small. In addition, the abovementioned detection was the only one detection during first two months of this seismic investigation (more about SEIS, see Lognonné et al. 2019). Up till now more successful has been an exploration done by MARSIS (Mars Advanced Radar for Subsurface and Ionosphere Sounding) onboard Mars Express mission, which have resulted in highly probable detection of liquid water under south polar glacial layers. Orosei et al. (2018) indicated that a bright feature visible in the instrument's results has high relative dielectric permittivity $(>15)$ that can be interpreted as a stable body of liquid water. However, radar sounding gives the best results almost solely in polar areas, due to dielectric properties of ices, regolith, and rocks, and future Mars exploration is planned almost solely in equatorial regions, where insolation and temperature is much higher. Therefore some other methods have been proposed.

One of these methods is ELF prospecting (Kozakiewicz et al. 2016). Only in cases of a high-conductivity planetary surface, like on Earth, the ground has very little influence on ELF propagation. For conductivities slightly lower than $10^{-4} \mathrm{~S} / \mathrm{m}$, ELF waves propagate under the 
planetary subsurface, and can be used as a tool for underground exploration (Kozakiewicz et al. 2015). On Mars, as there is no liquid water at the surface, the upper parts of the lithosphere must be characterized by low conductivity values, ca. $10^{-7} \mathrm{~S} / \mathrm{m}$ (Berthelier et al. 2000). Therefore, if there is underground water, which greatly increases subsurface conductivity, than its presence should be easily indicated in ELF measurements (Kozakiewicz et al. 2015).

\section{CONCLUSIONS AND FUTURE PLANS}

Many authors have studied Schumann resonance phenomenon on Mars (Sukhorukov 1991, Pechony and Price 2004, Molina-Cuberos et al. 2006, Yang et al. 2006, Soriano et al. 2007, Kozakiewicz et al. 2015, Toledo-Redondo et al. 2017, Haider et al. 2019), as it is a very informative tool in planetary exploration because of its global nature (Berthelier et al. 2000, Aplin et al. 2008, Harrison et al. 2008). But even if Schumann resonance are not generated on Mars, or generated only seasonally, the intensity of dust activity on Mars should provide enough ELF signals to measure the properties of the Martian cavity; under the assumption that Mars dust events generate ELF waves.

For Martian ELF investigation to become a reality, it is necessary to prove its capabilities on Earth. A prototype of ELF Martian station should be tested in terrestrial desert environments in order to measure signals in ELF range generated by electrical discharges in dust storms, and to study an impact of aeolian transport, including dust deposition and sand saltation, on the operating characteristic of the station.

Acknowledgments. This work has been supported by the National Science Centre Grant: 2015/19/B/ST9/01710.

\section{References}

Anderson, M.M., A.P. Siemion, W.C. Barrot, G.C. Bower, G.T. Delory, I. De Pater, and D. Werthimer (2012), The Allen telescope array search for electrostatic discharges on Mars, Astrophys. J. 744, 15, 1-13, DOI: 10.1088/0004-637X/744/1/15.

Aplin, K.L., R.G. Harrison, and M.J. Rycroft (2008), Investigating Earth's atmospheric electricity: a role model for planetary studies, Space Sci. Rev. 137, 11-27, DOI: 10.1007/978-0-387-87664$1 \_3$.

Aplin, K.L., T. Goodman, K.L. Herpoldt, and C.J. Davis (2012), Laboratory analogues of Martian electrostatic discharges, Planet. Space Sci. 69, 100-104, DOI: 10.1016/j.pss.2012.04.002.

Berthelier, J.J., R. Grard, H. Laakso, and M. Parrot (2000), ARES, atmospheric relaxation and electric field sensor, the electric field experiment on NETLANDER, Planet. Space Sci. 48, 1193-1200, DOI: 10.1016/S0032-0633(00)00103-3.

Cantor, B.A., P.B. James, M. Caplinger, and M.J. Wolff (2001), Martian dust storms: 1999 Mars Orbiter Camera observations, J. Geophys. Res. 106, E10, 23653-23687, DOI: 10.1029/2000JE001310.

Cantor, B.A., K.M. Kanak, and K.S. Edgett (2006), Mars Orbiter Camera observations of Martian dust devils and their tracks (September 1997 to January 2006) and evaluation of theoretical vortex models, J. Geophys. Res. 111, E12002, DOI: 10.1029/2006JE002700.

Eden, H.F., and B. Vonnegut (1973), Electrical breakdown caused by dust motion in low-pressure atmosphere: Consideration of Mars, Science 180, 962-963, DOI: 10.1126/science.180.4089.962.

Farrell, W.M., et al. (2004), Electric and magnetic signatures of dust devils from the 2000-2001 MATADOR desert tests, J. Geophys. Res. 109, E03004, DOI: 10.1029/2003JE002088. 
Fisher, J.A., M.I. Richardson, C.E. Newman, M.A. Szwast, C. Graf, S. Basu, S.P. Ewald, A.D. Toigo, and R.J. Wilson (2005), A survey of Martian dust devil activity using Mars Global Surveyor Mars Orbiter Camera images, J. Geophys. Res. 110, E03004, DOI: 10.1029/2003JE002165.

Forward, K.M., D.J. Lacks, and R.M. Sankaran (2009), Particle-size dependent bipolar charging of Martian regolith simulant, Geophys. Res. Lett. 36, L13201, DOI: 10.1029/2009GL038589.

Freier, G.D. (1960), The electric field of a large dust devil, J. Geophys Res. 65, 10, 3504, DOI: 10.1029/ JZ065i010p03504.

Greeley, R., et al. (2006), Active dust devils in Gusev crater, Mars: Observations from the Mars Exploration Rover Spirit, J. Geophys. Res. 111, E12S09, DOI: 10.1029/2006JE002743.

Gurnett, D.A., D.D. Morgan, L.J. Granroth, B.A. Cantor, W.M. Farrell, and J.R. Espley (2010), Nondetection of impulsive radio signals from lightning in Martian dust storms using the radar receiver on the Mars Express spacecraft, Geophys. Res. Lett. 37, 17, DOI: 10.1029/ 2010GL044368.

Haider, S.A., J.P. Pabari, J. Masoom, and S.Y. Shah (2019), Schumann resonance frequency and conductivity in the nighttime ionosphere of Mars: A source for lightning, Adv. Space Res. 63, 7, 2260-2266, DOI: 10.1016/j.asr.2018.12.006.

Harrison, R.G., K.L. Aplin, F. Leblanc, and Y. Yair (2008), Planetary Atmospheric Electricity, Space Sci. Rev. 137, 5-10.

Houser, J.G., W.M. Farrell, and S.M. Metzger (2003), ULF and ELF magnetic activity from a terrestrial dust devil, Geophys. Res. Lett. 30, 1027, DOI: 10.1029/2001GL014144.

Kok, J.F., and N.O. Renno (2009), Electrification of wind-blown sand on Mars and its implications for atmospheric chemistry, Geophys. Res. Lett. 36, L05202, DOI: 10.1029/2008GL036691.

Kozakiewicz, J., A. Kulak, and J. Mlynarczyk (2015), Analytical modeling of Schumann resonance and ELF propagation parameters on Mars with a multi-layered ground, Planet. Space Sci. 117, 127135, DOI: 10.1016/j.pss.2015.05.019.

Kozakiewicz, J., A. Kulak, J. Kubisz, and K. Zietara (2016), Extremely low frequency electromagnetic investigation on Mars, Earth Moon Planets 118, 2, 103-115, DOI: 10.1007/s11038-016-9493-2.

Lognonné, P., W.B. Banerdt, D. Giardini et al. (2019), SEIS: Insight's seismic experiment for internal structure of Mars, Space Sci. Rev. 215, 12, DOI: 10.1007/s11214-018-0574-6.

Martin, L.J., and R.W. Zurek (1993), An analysis of the history of dust storm activity on Mars, J. Geophys. Res. 98, 3221-3246, DOI: 10.1029/92JE02937.

Molina-Cuberos, G.J., J.A. Morente, B.P. Besser, J. Porti, H. Lichtenegger, K. Schwingenschuh, A. Salinas, and J. Margineda (2006), Schumann resonances as a tool to study the lower ionospheric structure of Mars, Radio Sci. 41, RS1003, DOI: 10.1029/2004RS003187.

Orosei, R., S. Lauro, E. Pettinelli, A. Cicchetti, M. Coradini, B. Cosciotti, F. Di Paolo, E. Flamini, E. Mattei, M. Pajola, F. Soldovieri, M. Cartacci, F. Cassenti, A. Frigeri, S. Giuppi, R. Martufi, A. Masdea, G. Mitri, C. Nenna, R. Noschese, M. Restano, and R. Seu (2018), Radar evidence of subglacial liquid water on Mars, Science 361, 6401, 490-493, DOI: 10.1126/science.aar7268.

Pechony, O., and C. Price (2004), Schumann resonance parameters calculated with a partially uniform knee model on Earth, Venus, Mars, and Titan, Radio Sci. 39, RS5007, DOI: 10.1029/2004 RS003056.

Qu, J., Yan Muhong, Dong Guangrong, Zhang Hongfa, Zu Ruiping, Tuo Wanquan, Zhao Aiguo, Xiao Zhenghua, Li Fang, and Yang Bao (2004), Wind tunnel simulation experiment and investigation on the electrification of sandstorms, Science in China Ser. D Earth Sci. 47, 6, 529-539.

Ruf, C., N.O. Renno, J.F. Kok, E. Bandelier, M.J. Sander, S. Gross, L. Skjerve, and B. Cantor (2009), Emission of non-thermal microwave radiation by a Martian dust storm, Geophys. Res. Lett. 36, L13202, DOI: 10.1029/2009GL038715.

Soriano, A., E.A. Navarro, J.A. Morente, and J.A. Portí (2007), A numerical study of the Schumann resonances in Mars with the FDTD method, J. Geophys. Res. 112, A06311, DOI: 10.1029/2007JA012281. 
Stow, C.D. (1969), Dust and sand storm electrification, Weather 24, 134-140.

Sukhorukov, A.I. (1991), On the Schumann resonances on Mars, Planet. Space Sci. 39, 12, 1673, DOI: 10.1016/0032-0633(91)90028-9.

Toledo-Redondo, S., A. Salinas, J. Portí, O. Witasse, S. Cardnell, J. Fornieles, G.J. Molina-Cuberos, G. Déprez, and F. Montmessin (2017), Schumann resonances at Mars: Effects of the day-night asymmetry and the dust-loaded ionosphere, Geophys. Res. Lett. 44, 648-656, DOI: 10.1002/ 2016GL071635.

Yang, H., V.P. Pasko, and Y. Yair (2006), Three-dimensional finite difference time domain modeling of the Schumann resonance parameters on Titan, Venus and Mars, Radio Sci. 41, RS2S03, DOI: $10.1029 / 2005 R S 003431$.

\section{BADANIE MARSA ZA POMOCĄ FAL ELF}

\section{Streszczenie}

W środowisku marsjańskim fale elektromagnetyczne ekstremalnie niskich częstotliwości (ELF, Extremely Low Frequency, $3 \mathrm{~Hz}-3 \mathrm{kHz}$ ) są słabo tłumione i mogą się propagować dookoła planety we wnęce ograniczonej z jednej strony przez jonosferę, a $\mathrm{z}$ drugiej przez przewodzące warstwy gruntu. Badania prowadzone za pomocą stacji ELF na Marsie mogą mieć nieco inne zastosowanie niż na Ziemi, ze względu na to, iż fale ELF wnikają w grunt marsjański na znacznie większe głębokości niż ma to miejsce na Ziemi. W związku z tym możliwe jest badanie za pomoca fal ELF warstw podpowierzchniowych Marsa. Ponadto prawdopodobnym źródłem fal ELF na Marsie są wyładowania elektryczne generowane przez burze i diabełki pyłowe, z czego wynika, że pomiary ELF mogą pomóc w badaniach aktywności pyłowej, która w znacznej mierze wpływa na globalne właściwości atmosfery Marsa. 



\title{
Schumann Resonance Monitoring (ELF) Records as Remote Reference Data for Magnetotelluric Soundings
}

\author{
Anne NESKA ${ }^{1, \bowtie}$, Szymon ORYŃSKI ${ }^{1}$, and Krzysztof NOWOŻYŃSKI ${ }^{1}$ \\ ${ }^{1}$ Institute of Geophysics, Polish Academy of Sciences, Warsaw, Poland \\ anne@igf.edu.pl
}

Usually, scientific, continuous records of electromagnetic variations in the ELF frequency range are collected with the aim to investigate phenomena (e.g., signal generation and propagation mechanisms, signal detection, quantification, and monitoring) that occur above the surface of the solid Earth. In this contribution we want to demonstrate that such data also have the potential to act as an important auxiliary for investigation of subsurface structures.

We speak here about the context of magnetotellurics, a sounding method that is applied to make statements about the electric resistivity distribution in the solid Earth due to underlying rocks, sediments, melts, fluids, etc. The way ELF records can contribute to this method is to use them as so-called remote-reference data during the data processing.

The background of that approach is that the magnetotelluric transfer functions of a station (which are the outcome of the processing and which contain the desired information about subsurface resistivity distribution) are often seriously biased because of various noise problems. Such a bias can be avoided, or corrected for, if synchronously measured data of a second station are included in the processing. Usually this second station is just another magnetotelluric station of the same array. The idea described in this contribution is, however, to use ELF monitoring data for this purpose. In a technical sense there is no difference between such data and part of the magnetotelluric records, and there is a number of arguments from a logistic and data-quality point of view supporting such a concept.

Examples of magnetotelluric results benefitting from ELF monitoring data will be shown, where the reference data come from IG PAS station records in Poland and Spitsbergen (cf. Neska et al. 2019). Regions under the investigation were Polish Pomerania and Mazovia. Magnetotelluric measurements were conducted with German Metronix and Canadian Phoenix instruments, respectively.

Another application, or benefit, from ELF records for our soundings is that the spatial properties of the well-understood Schumann resonances can help to assess some questions still controversial in the magnetotelluric community, e.g., how large the distance between the magnetotelluric and the remote-reference station may be. This will be elaborated in the conference presentation, too. 
References

Neska, M., P. Czubak, and J. Reda (2019), Schumann resonance monitoring in Suwałki (Poland) and Hornsund (Spitsbergen), Publs. Inst. Geophys. Pol. Acad. Sc. 425 (M-32), 39-43 (this issue).

\section{OBSERWACJE ELF JAKO DANE REFERENCYJNE W MAGNETOTELLURYCE}

\section{Streszczenie}

Ciągłe zapisy zmian pola elektromagnetycznego w zakresie częstotliwości ELF są wykorzystywane do badania różnych zjawisk (np. do mechanizmów propagacji, detekcji i kwantyfikacji sygnału), które występują nad powierzchnią Ziemi. W pracy tej chcemy wykazać, że takie dane potencjalnie mogą również służyć jako istotny element pomocniczy przy badaniach struktur podpowierzchniowych.

Mamy tutaj na myśli sondowania magnetotelluryczne. Metodą tą można zbadać rozkład oporności elektrycznej podłoża i na tej podstawie rozpoznać struktury geologiczne (skały, osady, magma, itp.). Zapisy ELF mogą być wykorzystywane w magnetotelluryce jako tzw. dane referencyjne w czasie obróbki danych.

Magnetotelluryczne funkcje przejścia, które powstają w wyniku obróbki danych i zawierają pożądaną informację o podłożu, na skutek różnorodnych zakłóceń bywają zniekształcone. W takim przypadku znajdują zastosowanie synchronicznie zmierzone dane referencyjne w celu eliminacji zniekształceń. Zazwyczaj dane referencyjne pochodzą z innej stacji magnetotellurycznej należącej do tej samej siatki pomiarowej. Dane magnetotelluryczne oraz pomiary ELF mają wspólny element jakim są składowe poziome magnetyczne. Koncepcją tej pracy jest zademonstrowanie, że równie dobrymi danymi referencyjnymi mogą być obserwacje ELF (ze względów logistycznych oraz samej jakości danych).

Udane zastosowania danych ELF przy obróbce magnetotellurycznej zostaną poparte przykładami, gdzie dane referencyjne pochodzą z zapisów stacji IGF PAN w Polsce i na Spitsbergenie (Neska i in. 2019). Rejon badań obejmował obszar Pomorza i Mazowsza. Pomiary magnetotelluryczne wykonane były aparaturą niemieckiej firmy Metronix oraz kanadyjskiej Phoenix.

Właściwości przestrzenne zjawiska rezonansu Schumanna są stosunkowo dobrze poznane. Taka znajomość może pomagać w rozstrzygnięciu ważnego w magnetotelluryce pytania: „Jaka może być maksymalna odległość pomiędzy stacją magnetotelluryczną, a jej referencją?”. Taka dodatkowa korzyść użycia danych ELF w magnetotelluryce również zostanie przedstawiona $\mathrm{w}$ prezentacji. 


\title{
ELF Signatures in Low and High Radio Frequency Signals
}

\author{
Mariusz POZOGA ${ }^{1, \bowtie}$, Barbara MATYJASIAK ${ }^{1}$, Hanna ROTHKAEHL $^{1}$, \\ Roman WRONOWSKI ${ }^{1}$, and Łukasz TOMASIK ${ }^{1}$ \\ ${ }^{1}$ Space Research Centre, Polish Academy of Sciences, Warszawa, Poland \\ pozoga@cbk.waw.pl
}

\section{INTRODUCTION}

The radio waves in ranges from LF (Low Frequency) to HF (High Frequency) which propagate in the Earth's atmosphere are affected by the ionosphere. Observation of phase, amplitude and direction of incoming radio signals can provide information about the current state of the ionised medium. In our studies for HF observations we use PL610 LOFAR (Low-Frequency Array for Radio astronomy) station, which is located in Astrogeodynamical Observatory in Borowiec. For LF and MF (Medium Frequency) band measurements dedicated receiver based on Universal Software Radio Peripheral (USRP) is used. We observe phase and amplitude signals from radio broadcast station. The time measurement is based on GPS.

\section{MEASUREMENTS}

\subsection{PL610 station}

The single LOFAR station is divided into two antenna fields, the Low Band Antennas (LBA) field and the High Band Antenna (HBA) field, which consist of a set of 96 antennas. Each of antennas can be used for independent observation of the radio signals. Due to its construction, it is possible for LOFAR station to measure the angle of incidence of the incoming signals and its changes in time. The LBA, which operates in the $8-90 \mathrm{MHz}$ frequency range (de Vos et al. 2009), allows to measure the signals from broadcasting station reflected from the ionosphere. This gives us possibility to observe many phenomena, such as multi-path propagation and small changes of the incidence angle, and shows that LOFAR instrument is valuable tool for ionosphere monitoring.

\subsection{LF/MF phase monitor}

The measurements below frequency of $8 \mathrm{MHz}$ are not possible with LOFAR station. For this reason, we use a special system consisting of USPR software defined radio (SDR) and Wellbrook loop antenna located in Warsaw. The time measure is provided by GPS (PPS). It works 
in frequency range $30 \mathrm{kHz}-30 \mathrm{MHz}$. Current version doesn't allow to measure incidence direction of the signals. For this reason we use signals from commercial broadcast station. The AM transmission in addition to the audio signals contains a carrier. We use 3 transmitters: Polskie Radio Program 1 (1 MW) at $255 \mathrm{kHz}$ from Solec Kujawski (Poland), BBC Radio 4 $(500 \mathrm{~kW})$ at $198 \mathrm{kHz}$ transmitted from Droitwich (England) and DCF77 signal $(50 \mathrm{~kW})$ at $77.5 \mathrm{kHz}$ from Mainflingen (Germany). Selected radio stations have stable carrier frequencies controlled by an atomic clock. Precise phase measurements can provide evolution of the phase during the day as well as a rapid, small changes.

\section{RESULTS}

We observe three kinds of phenomena. The first one are rapid changes of signals parameters caused by multi-path nature of the HF propagation. The second type - slow variations which are related to daily changes of the ionosphere and the last one observed as a quick periodic changes of measured parameters.

\section{CONCLUSIONS}

The presented analysis of radio signals variations is a valuable tool for monitoring and studying changes of the ionosphere, and thus can be used successfully for space weather condition diagnosis.

References

de Vos, M., A.W. Gunst, and R. Nijboer (2009), The LOFAR telescope: system architecture and signal processing, Proc. IEEE 97, 8, 1431-1437, DOI: 10.1109/JPROC.2009.2020509.

\section{SYGNATURY ELF W OBSERWACJACH SYGNALÓW RADIOWYCH NA FALACH DLUGICH I KRÓTKICH}

\section{Streszczenie}

Radiokomunikacja na falach krótkich bazuje na odbiciu fal radiowych od jonosfery. Również propagacja na niższych częstotliwościach, falach długich i średnich jest w dużej mierze zależna jest od jonosfery. Obserwacje komercyjnych rozgłośni radiowych mogą wnieść istotne informacje o stanie i zaburzeniach występujących w jonosferze.

Pomiary wykonane przy użyciu stacji PL610 systemu LOFAR na falach krótkich oraz własnej aparatury na falach długich i średnich pozwalają na monitorowanie zarówno dobowych jak i krótkookresowych zmian fazy. W pracy przedstawiamy wstępne wyniki wykonanych obserwacji. 


\title{
SuperDARN Radars - Introduction
}

\author{
Grzegorz GÓRAL ${ }^{1, \bowtie}$ \\ ${ }^{1}$ Warsaw, Poland \\ Grzegorz.Goral@pitradwar.com
}

\section{INTRODUCTION}

SuperDARN radars are coherent scatter radars which use the Bragg scattering phenomenon on structures characterised by a certain spatial periodicity whose distances are comparable to the sounding wavelength. For a certain range of the probe's wavelength, in the case of objects with a periodic structure and constant distances between the elements of the structure, a coherent echo superposition occurs, which results in the amplification or weakening of the signal by interference. In this way, an echo signal gain towards the radar receiver can be obtained. We have such a case to deal with a specific ratio of the probe's wavelength to the distance between the elements of the structure of the observed object:

$$
d=\frac{\lambda_{t}}{2 \cdot \cos \theta}
$$

where:

$d$-distance between elements of the structure,

$\lambda_{\mathrm{t}}$ - length of incident wave,

$\theta$ - incident angle (here, the angle between the parallel to the element of the structure and the direction of the incident radiation).

In the case of used frequencies from 8 to $22 \mathrm{MHz}$, it gives a size from several to over a dozen meters.

A characteristic feature of ionospheric irregularities is their orientation along the lines of the magnetic field. For this reason, the incoming wave emitted by the radar should be orthogonal to the geomagnetic field in order for the scattered signal be able to return to the antenna. This poses certain requirements for the regions of the ionosphere that can be observed by coherent scatter radars. For example, at high latitudes, where the field lines are almost vertical, it is impossible to meet the orthogonality condition above layer E (90-130 km). At VHF frequencies and higher, the signal propagates towards space. Using the frequencies from the HF band, ionospheric refraction allows to achieve the orthogonality criterion for layers $E$ and $F$. In the case of ionosphere irregularities in this region, the radar signal will be scattered in the direction of 
transmission. The construction and operation of SuperDARN radars has been thoroughly presented in the works of Greenwald (2012) and Lester (2013).

\section{A BRIEF HISTORY OF DARN RADARS}

The first cases of using coherent scatter radar to observe ionospheric convection took place at the end of the 1970s using the STARE (Scandinavian Twin Auroral Radar Experiment) installation in northern Scandinavia (Greenwald et al. 1995). It consists of two bistatic pulse radars with phase control, located in Malvik (Norway) and Hankasalmi (Finland). Their common field of vision covers an area of around $400 \times 400 \mathrm{~km}$. The radar measures the intensity and speed of the Doppler ionospheric irregularities in layer $E$. The device offers a spatial resolution of $20 \times 20 \mathrm{~km}$ and a time resolution of 20 seconds. At the time of its creation it was the only radar allowing two-dimensional observation of convection paths of the ionospheric plasma.

The effects of the research conducted using the STARE radars were an impulse to build further analogous installations operating in the VHF band. They were SABER, located in Wick (Scotland) and Uppsala (Sweden) and BARS located in Red Lake and Nipawin (Canada). These radars were part of the planned Dual Auroral Radar Network (DARN) which was the answer to NASA's project Origins of Plasmas in the Earth's Neighborhood (OPEN). The field of view of each radar covered the sector $4^{\circ}$ magnetic width and 1 hour MLT.

The first radar using coherent scattering is the Goose Bay installation constructed by Johns Hopkins University Applied Physics Laboratory. The radar uses a phase-controlled antenna and operates on a frequency of $8 \div 20 \mathrm{MHz}$ (HF band). Its field of view is $52^{\circ}$ around the axis running along $5^{\circ} \mathrm{E}$ and the range from a few hundred to over $3000 \mathrm{~km}$. Reflections in $F$ layer are usually recorded in the range of $10-60 \%$ of this range. Radar operates continuously and provides measurement data since its launch in 1983.

The next HF radars were the French-Canadian SHERPA (located in Quebec) and the American-British radar in Antarctica, built as part of the Polar Anglo-American Conjugate Experiment (PACE) project. The experience gained during the tests using the above installations showed the benefits of observations made simultaneously on two radars. This configuration has been particularly helpful when tracking convective plasma motions. PACE radars were able to provide information about plasma flows in adjacent hemispheres and changes in the routes of these flows within minutes. SHERPA radar, observing in parallel with the radar from Goose Bay (to which it is similar in design), also showed the usefulness of observations from two directions. It was possible to monitor time changes with a 90 second time resolution.

In 1990 in Lindau (Germany) at the DARN Investigation Team meeting, a decision was made to expand the global network of HF radars to widen the coverage and measurement capabilities of the DARN system. The new network gained the name SuperDARN which was supposed to indicate a significant development of the DARN concept. Another important step in the development of the SuperDARN network was 2005, when the first mid-latitude radar was launched in Wallops (Oksavik et al. 2006). This radar has a field of view facing north between the two auroral radar fields of Goose Bay and Kapuskasing (both in Canada). The location of radars on mid-latitudes is particularly important in the case of observing magnetic storms (Lester 2013). During these phenomena there occur periods when the radar echo disappears due to absorption of the HF signal or insufficient ionization of the medium for wave propagation. Mid-latitude radars do not have that inconvenience, hence they are often referred to as StormDARN.

The next installation was Japanese radar on Hokkaido (2007) and American radar in Blackstone (2008). A big step in the development of a mid-latitude network of radars took place in 2010 with the start of the construction of a set of 8 radars as part of the MSI (Mid Size Infrastructure) initiative. The first pair of radars was installed in Fort Hays (Kansas USA). The next 
ones were located in Christmas Valley (Oregon USA), Aleutes and Azores. In 2012, the first of four Siberian radars in Yekaterinburg was launched. This is an important supplement to the SuperDARN network in a geographic area long ignored in research.

\section{SCIENTIFIC GOALS}

The example areas of research on which coherent scatter radars are applicable are presented below:

\section{Analysis of ionospheric convection}

The main goal that guided the SuperDARN radar concept were large-scale (almost global) measurements of ionospheric convection caused by the interaction of the solar wind with the magnetosphere. In particular, it is a magnetic reconnection between the field of the magnetic sheath and the geomagnetic field on the dayside and between the open field lines belonging to two lobes of the Earth's magnetic tail. SuperDARN radars have contributed to learning about the mechanisms governing the phenomenon of Poleward Moving Radar Auroral Form (PMRAF) (Milan et al. 2000, Neudegg et al. 1999, Wild et al. 2001, Wild et al. 2003) - increasing the intensity of ionospheric plasma flows induced by the particle stream from the magnetosphere. Radar observations have allowed also to create global maps of ionospheric convection and to study the reaction of the ionosphere to changes in the interplanetary magnetic field (IMF) (Taylor et al. 1998, Cousins and Shepherd 2010). SuperDARN radars, as the only tool, allow for continuous measurements to estimate the field of electric reconnection as a function of time for many timezones with a resolution of several minutes (Chisham et al. 2008). Another of the discoveries made using radar are large-scale plasma motions on the nightside in relatively calm geomagnetic conditions, probably caused by the twisting of magnetic field lines in the Earth's magnetic tail by the action of IMF (Grocott et al. 2005, Walker et al. 2002). SuperDARN observations also concern convection in the ionosphere caused by processes associated with magnetospheric substorms (Bristow and Jensen 2007, Grocott et al. 2006, Yeoman et al. 2000). In particular, among the observed on mid-latitudes SuperDARN radar forms of ionospheric irregularities, we can distinguish plasma motions called SAPS (SubAuroral Polarization Streams), caused by strong electric fields occurring during magnetic storms (Clausen et al. 2012, Oksavik et al. 2006).

\section{Monitoring of the magnetosphere and ionosphere structure}

The ionospheric convection tests mentioned in the previous chapter are based on measurements of Doppler velocities performed with radar. In addition, it is also possible to measure the power of the received echo and the width of its spectrum. This is useful in determining the position of polar cusp based on observations of widening the spectrum of the scattered signal (Baker et al. 1995) and determining the boundary between the region where the magnetic field lines are closed (narrow spectrum) and those in which they are open (widened spectrum). The border region is called in the literature (Lester 2013) Spectral Width Boundary (SWB). Its knowledge is important in determining the speed of reconnection, which is required in the measurements described in the previous point.

The measurement of the signal power reaching the receiver, in many cases, can be an indicator of the distribution of electron density in the ionosphere (Oksavik et al. 2010). This applies, while measuring convection, to forecasting ionospheric plasma movements (polar patches) in the polar region (Milan et al. 2002, Oksavik et al. 2010). 


\section{ULF waves}

SuperDARN radars are also a useful tool in studies on magnetohydrodynamic (MHD) ultralow frequency waves, with periods on the order of $45 \div 600 \mathrm{~s}$. They constitute a significant means of energy transfer within the magnetosphere. They are caused by external phenomena, such as, for example, solar wind flows through a magnetopause that evokes Kelvin-Helmholtz waves. These waves have a relatively large size. Waves of smaller sizes in the azimuth are generated by internal mechanisms, like drift of large sets of high-energy particles in the magnetosphere. The tests were carried out, during which high-power transmitters had generated regions of increased ionization from which the radar signal was then scattered. During the experiments, small-sized waves were observed (Yeoman et al. 1997). These studies have contributed to a better understanding of the mechanisms of the wave-particle interaction responsible for the induction of these vibrations (Yeoman et al. 2012). In this group of tests, a certain modification is the Stereo technique (Lester et al. 2004) allowing simultaneous operation of radars in two different modes, one of which can offer high time resolution. Observations of SuperDARN radars usually involve modulated electric fields in the ionosphere that are related to waves $(\mathrm{Ru}-$ ohoniemi et al. 1991). However, sometimes the impact of waves is manifested in change at the point of dispersion, which can be seen in echoes from the ground (Ponomarenko et al. 2003).

\section{SIMULATION RESULTS}

One of the key issues when choosing a location for a new SuperDARN station is to determine its potential for observation. It depends on the local configuration of the geomagnetic field, the current ionosphere structure and the operating frequency of the transmitter. One can use the ray tracing software by Jones and Stephenson (1975) to track the propagation path of the pulse emitted by the radar and determining points in which the wave vector is perpendicular to the local magnetic field of the Earth. Such a condition will allow for the scattering of the radar signal emitted by the antenna back in the direction of transmission. Simulations do not include such parameters of the probe signal as the shape of the pulse and its time parameters.

Figure 1 shows examples of calculation results for the conditions of echo formation for a signal sent from hypothetical radar located in the area of Wierzbowa $\left(51^{\circ} 23^{\prime} \mathrm{N} 15^{\circ} 45^{\prime} \mathrm{E}\right)$. The location was initially considered in the plans of Polish scientists for the SuperDARN infrastructure in Poland (e.g. Popielawska et al. 2011, Góral et al. 2013). The horizontal axis represents the distance from the transmitter and the vertical axis the distance from the surface of the Earth. The results shown correspond to the beam at an angle of $66^{\circ}$ to the geographic north and elevation angles in the range from $5^{\circ}$ to $60^{\circ}$ with a step of $5^{\circ}$. The transmitter's operating frequency was set to $9 \mathrm{MHz}$. The observation point was 16/03/2015, 22:00 UT. Marked points are regions where the wave vector is orthogonal to the local geomagnetic field vector, which would allow observation of ionospheric irregularities in these places. Figure 2 shows the effect of increasing the operating frequency up to $16 \mathrm{MHz}$. As you can see, this results in a given tendency to penetrate the ionosphere by the emitted wave and "escape" without meeting the criterion of orthogonality. Figure 3 illustrates the horizontal distribution of potential sources of strong ionospheric echo (marked with crosses places in which the wave vector is orthogonal to the local geomagnetic field vector) for the orientation of the radar axis in the direction of $30^{\circ}$. The sounding beam's azimuth angle changed from $-3^{\circ}$ to $66^{\circ}$ with a step of $3^{\circ}$. The rest of parameters remained as in the case of Figure 1. Figure 4 shows the horizontal echo distribution for the orientation of the radar axis in the $-40^{\circ}$ direction and changing the operating frequency to $9 \mathrm{MHz}$. In this case sounding beam's azimuth angle changed from $-73^{\circ}$ to $-4^{\circ}$ with a step of $3^{\circ}$. In the calculations the IRI (Bilitza 2014) ionosphere model in the 2012 version and the IGRF (Thebault et al. 2015) geomagnetic field model were used. 


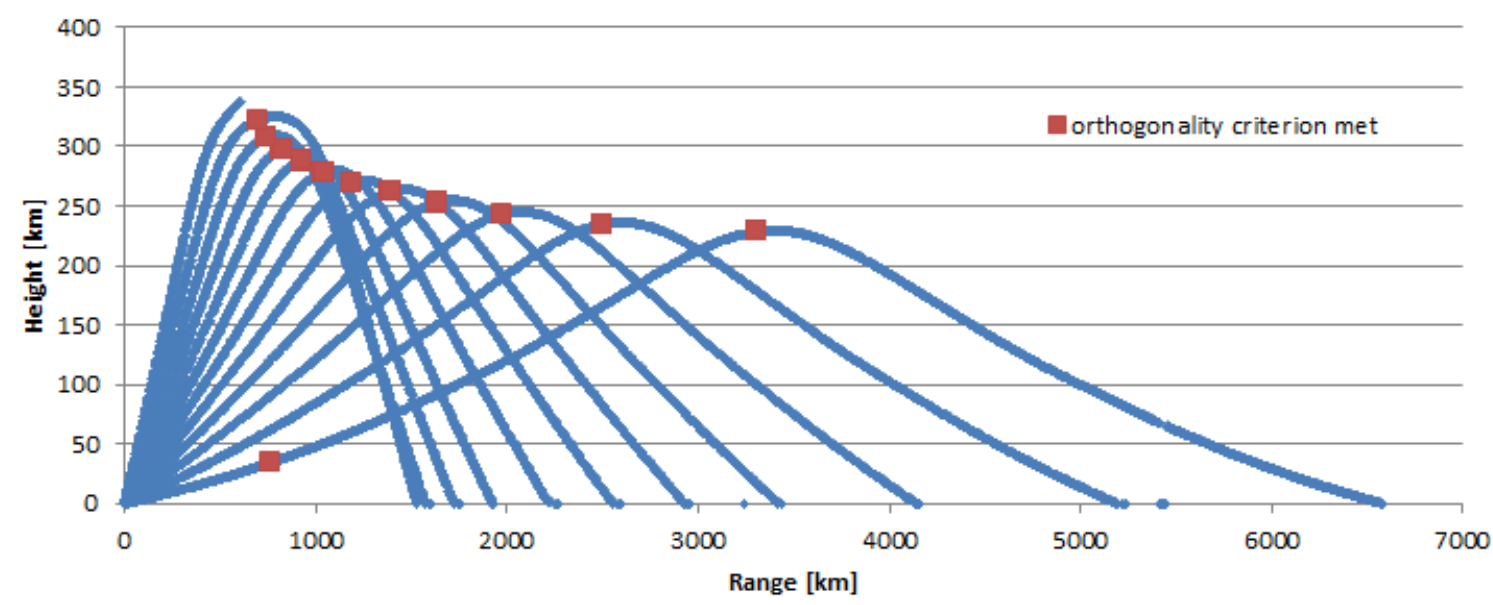

Fig. 1. Ray paths for the HF radar simulation described in the article. Operating frequency $9 \mathrm{MHz}$, radar axis $30^{\circ}$ (own calculations).

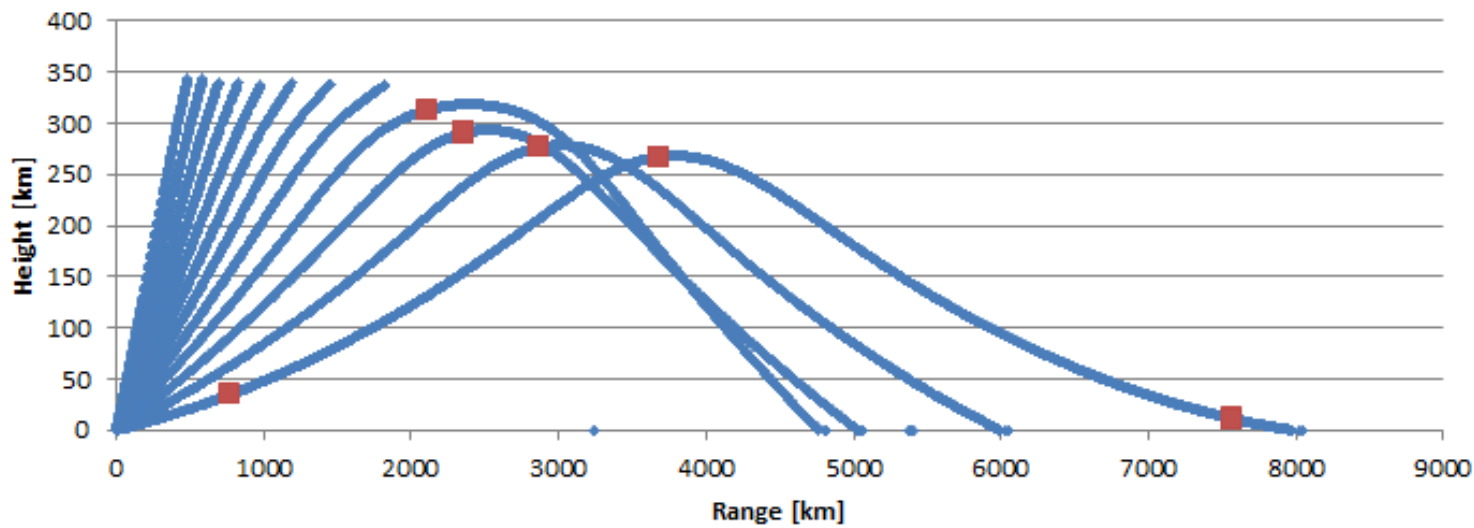

Fig. 2. Ray paths for the HF radar simulation described in the article. Operating frequency $16 \mathrm{MHz}$, radar axis $30^{\circ}$ (own calculations).

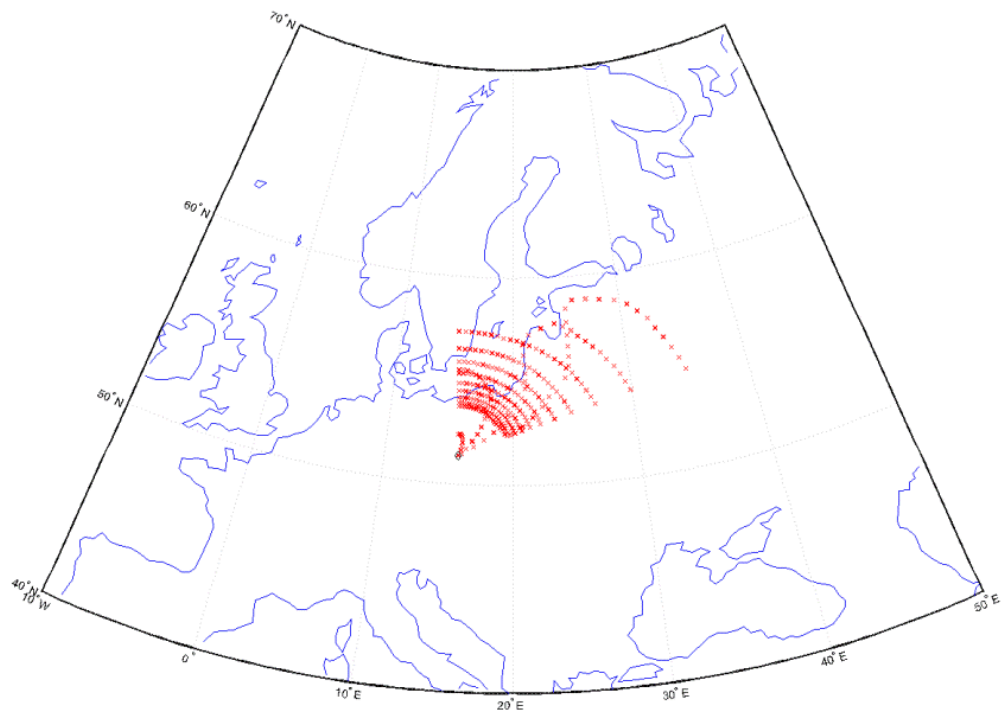

Fig. 3. Horizontal distribution of potential places of formation of a strong radar echo from ionospheric irregularities. Operating frequency $9 \mathrm{MHz}$, radar axis $30^{\circ}$. Red points are regions where the wave vector is orthogonal to the local geomagnetic field vector, which would allow observation of ionospheric irregularities in these places. (own calculations). 


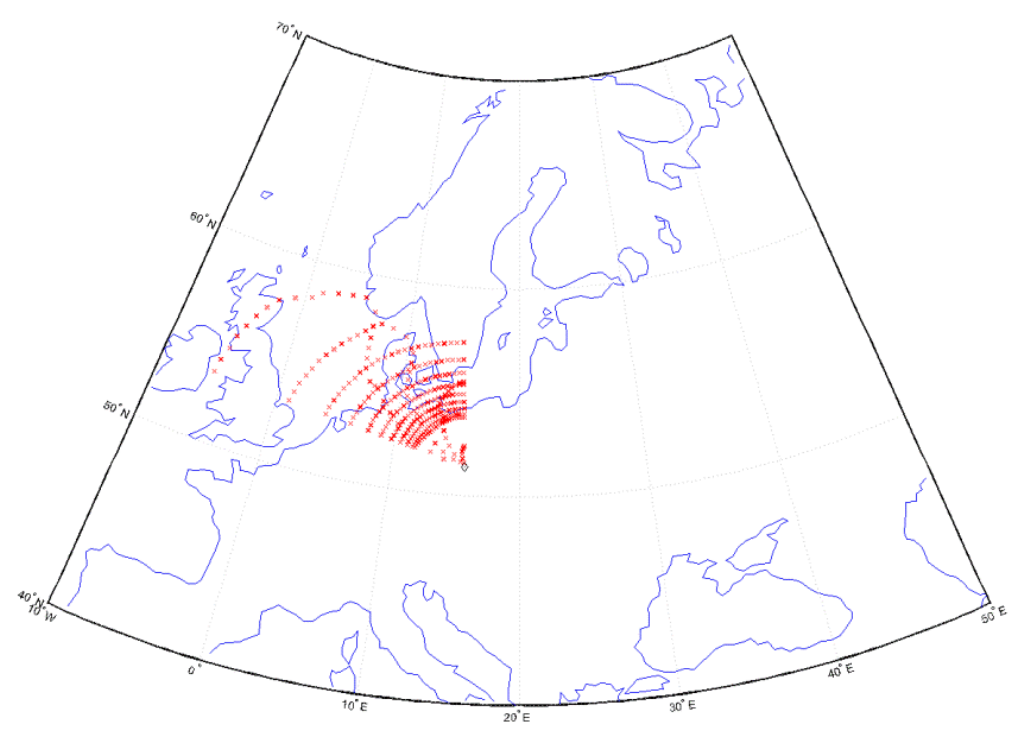

Fig. 4. Horizontal distribution of potential places of formation of a strong radar echo from ionospheric irregularities. Operating frequency $9 \mathrm{MHz}$, radar axis $-40^{\circ}$. Red points are regions where the wave vector is orthogonal to the local geomagnetic field vector, which would allow observation of ionospheric irregularities in these places. (own calculations).

\section{CONCLUSION}

A condition for the existence of ionospheric echoes is, next to the fulfillment of the orthogonality criterion, the occurrence of ionospheric irregularities in the $F$ layer. Otherwise, the radar signal will not be scattered. Observations of these phenomena on mid-latitudes have been confirmed in a number of works (Clausen et al. 2012, Hosokawa and Nishitani 2010, de Larquier et al. 2011, Ribeiro et al. 2012). The simulations show that by choosing the appropriate frequency it is possible to obtain favorable conditions for observing irregularities occurring in the ionospheric $F$ layer (in geomagnetically quiet conditions) at a distance of 500 to $3500 \mathrm{~km}$ from the transmitter.

\section{References}

Baker, K.B., J.R. Dudeney, R.A. Greenwald, M. Pinnock, P.T. Newell, A.S. Rodger, N. Mattin, and C.-I. Meng (1995), HF radar signatures of the cusp and low-latitude boundary layer, J. Geophys. Res. 100, 7671-7695, DOI: 10.1029/94JA01481.

Bilitza, D. (2014), The International Reference Ionosphere - Status 2013, Adv. Space Res. 55, 19141927.

Bristow, W.A., and P.A. Jensen (2007), A superposed epoch study of SuperDARN convection observations during substorms, J. Geophys. Res. 112, A06232, DOI: 10.1029/2006JA012049.

Chisham, G., M.P. Freeman, G.A. Abel, M.M. Lam, M. Pinnock, I.J. Coleman, S.E. Milan, M. Lester, W.A. Bristow, R.A. Greenwald, G.J. Sofko, and J.-P. Villain (2008), Remote sensing the spatial 
and temporal structure of magnetopause and magnetotail reconnection from the ionosphere, Rev. Geophys. 46, RG1004, DOI: 10.1029/2007RG000233.

Clausen, L.B.N., J.B.H. Baker, J.M. Ruohoniemi, R.A. Greenwald, E.G. Thomas, S.G. Shepherd, E.R. Talaat, W.A. Bristow, Y. Zheng, A.J. Coster, and S. Sazykin (2012), Large-scale observations of a subauroral polarization streams by midlatitude SuperDARN radars: Instantaneous longitudinal velocity variations, J. Geophys. Res. 117, A05306, DOI: 10.1029/2011JA017232.

Cousins, E.D.P., and S.G. Shepherd (2010), A dynamical model of high-latitude convection derived from SuperDARN plasma drift measurements, J. Geophys. Res. 115, A12329, DOI: 10.1029/ JA016017.

De Larquier, S., J.M. Ruohoniemi, J.B.H. Baker, N. Ravindran Varrier, and M. Lester (2011), First observations of the midlatitude evening anomaly using Super Dual Auroral Radar Network (SuperDARN) radars, J. Geophys Res. 116, A10321, DOI: 10.1029/2011JA016787.

Góral, G., P. Koperski, M. Kubicki, and A. Odzimek (2013), IRI-2011 ray paths simulation for midlatitude SuperDARN station in Poland, International Reference Ionosphere (IRI) Workshop 2013 "IRI and GNSS", 24-28 June 2013, Olsztyn, Poland.

Greenwald, R.A. (2012), Steering SuperDARN Radars - tutorial, http://vt.superdarn.org/tiki-download_file.php?fileId=1060, access 11.06.2019.

Greenwald, R.A., K.B. Baker, J.R. Dudeney, M. Pinnock, T.B. Jones, E.C. Thomas, J.-P. Villain, J.-C. Cerisier, C. Senior, C. Hanuise, R.D. Hunsucker, G. Sofko, J. Koehler, E. Nielsen, R. Pellinen, A.D.M. Walker, N. Sato, and H. Yamagishi (1995), DARN/SuperDARN A global view of the dynamics of high-latitude convection, Space Sci. Rev. 71, 761-796, DOI: 10.1007/BF00751350.

Grocott, A., T.K. Yeoman, S.E. Milan, and S.W.H. Cowley (2005), Interhemispheric observations of the ionospheric signature of tail reconnection during IMF-northward non-substorm intervals, Ann. Geophys. 23, 1763-1770, DOI: 10.5194/angeo-23-1763-2005.

Grocott, A., M. Lester, M.L. Parkinson, T.K. Yeoman, P.L. Dyson, J.C. Devlin, and H.U. Frey (2006), Towards a synthesis of substorm electrodynamics: HF radar and auroral observations, Ann. Geophys. 24, 3365-3381, DOI: 10.5194/angeo-24-3365-2006.

Hosokawa, K., and N. Nishitani (2010), Plasma irregularities in the duskside subauroral ionosphere as observed with midlatitude SuperDARN radar in Hokkaido, Japan, Radio Sci. 45, RS4003, DOI: 10.1029/2009RS004244.

Jones, R.M., and J.J. Stephenson (1975), A versatile three-dimensional ray tracing computer program for radio waves in the ionosphere, U.S. Department of Commerce Office of Telecommunications Report, 75-76.

Lester, M. (2013), The Super Dual Auroral Radar Network (SuperDARN): An overwiew of its development and science, Adv. Polar Sci. 24, 1, 1-11, DOI: 10.3724/SP.J.1085.2013.00001.

Lester, M., P.J. Chapman, S.W.H. Cowley, S.J. Crooks, J.A. Davies, P. Hamadyk, K.A. McWilliams, S.E. Milan, M.J. Parsons, D.B. Payne, E.C. Thomas, J.D. Thornhill, T.K. Yeoman, and R.J. Barnes (2004), Stereo CUTLASS - A new capability for the SuperDARN radars, Ann. Geophys. 22, 459-473, DOI: 10.5194/angeo-22-459-2004.

Milan, S.E., M. Lester, S.W.H. Cowley, and M. Brittnacher (2000), Convection and auroral response to a southward turning of the IMF: Polar UVI, CUTLASS and IMAGE signatures of transient flux transfer at the magnetopause, J. Geophys. Res. 105, 15741-15756, DOI: 10.1029/ 2000JA900022.

Milan, S.E., M. Lester, and T.K. Yeoman (2002), Polar patch formation revisited, summer and winter variations in dayside plasma structuring, Ann. Geophys. 20, 487-499.

Neudegg, D.A., T.K. Yeoman, S.W.H. Cowley, G. Provan, G. Haerendel, W. Baumjohann, U. Auster, K.H. Fornacon, E. Georgescu, and C.J. Owen (1999), A flux transfer event observed at the magnetopause by the Equator-S spacecraft and in the ionosphere by the CUTLASS HF radar, Ann. Geophys. 17, 707-711, DOI: 10.1007/s00585-999-0707-z. 
Oksavik, K., R.A. Greenwald, J.M. Ruohoniemi, M.R. Hairston, L.J. Paxton, J.B.H. Baker, J.W. Gjerloev, and R.J. Barnes (2006), First observations of the temporal/spatial variation of sub-auroral polarization stream from the SuperDARN Wallops HF Radar, Geophys. Res. Lett. 33, L12104, DOI: $10.1029 / 2006$ GL026256.

Oksavik, K., V. Barth, J. Moen, and M. Lester (2010), On the entry and transit of high-density plasma across the polar cap, J. Geophys. Res. 115, A12308, DOI: 10.1029/2010JA015817.

Ponomarenko, P.V., F.W. Menk, and C.L. Waters (2003), Visualization of ULF waves in SuperDARN data, Geophys. Res. Lett. 30, 1926, DOI: 10.1029/2003GL017757.

Popielawska, B., A. Odzimek, I. Stanislawska, M. Kubicki, M. Wernik, G. Góral, M. Grzesiak, and M. Pożoga (2011), SuperDARN in Poland - study of potential scientific benefits, SuperDARN Workshop 2011, May 30 - June 3, Dartmouth College, Hanover, New Hampshire, USA, http://superdarn.thayer.dartmouth.edu/workshop/proceedings.html.

Ribeiro, A.J., J.M. Ruohoniemi, J.B.H. Baker, L.B.N. Clausen, R.A. Greenwald, and M. Lester (2012), A survey of plasma irregularities as seen by the midlatitude Blackstone SuperDARN radar, J. Geophys. Res. 117, A02311, DOI: 10.1029/2011JA017207.

Ruohoniemi, J.M., R.A. Greenwald, K.B. Baker, and J.C. Samson (1991), HF radar observations of Pc5 field line resonances in the midnight early morning MLT sector, J. Geophys. Res. 96, 15697 15710, DOI: 10.1029/91JA00795.

Taylor, J.R., S.W.H. Cowley, T.K. Yeoman, R. Greenwald, G. Sofko, and J.-P. Villain (1998), SuperDARN studies of ionospheric convection in response to a northward turning of the interplanetary magnetic field on 23 March 1995, Ann. Geophys. 16, 549-565, DOI: 10.1016/S02731177(98)00173-2.

Thebault, E. et al. (2015), International Geomagnetic Reference Field: the $12^{\text {th }}$ generation, Earth Planets Space 67, 79, DOI: 10.1186/s40623-015-0228-9.

Walker, A.D.M., K.B. Baker, M. Pinnock, J.R. Dudeney, and J.P.S. Rash (2002), Radar observations of magnetospheric activity during extremely quiet solar wind conditions, J. Geophys. Res. 107, A4, 1038, DOI: 10.1029/2001JA000063.

Wild, J.A., S.W.H. Cowley, J.A. Davies, H. Khan, M. Lester, S.E. Milan, G. Provan, T.K. Yeoman, A. Balogh, M.W. Dunlop, K.-H. Fornacon, and E. Georgescu (2001), First simultaneous observations of flux transfer events at the high-latitude magnetopause by the Cluster spacecraft and pulsed radar signatures in the conjugate ionosphere by the CUTLASS and EISCAT radars, Ann. Geophys. 19, 1491-1508, DOI: 10.5194/angeo-19-1491-2001.

Wild, J.A., S.E. Milan, S.W.H. Cowley, M.W. Dunlop, C.J. Owen, J.M. Bosqued, M.G.G.T. Taylor, J.A. Davies, M. Lester, N. Sato, A.S. Yukimatu, A.N. Fazakerley, A. Balogh, and H. Rème (2003), Coordinated interhemispheric SuperDARN radar observations of the ionospheric response to flux transfer events observed by the Cluster spacecraft at the high-latitude magnetopause, Ann. Geophys. 21, 1807-1826, DOI: 10.5194/angeo-21-1807-2003.

Yeoman, T.K., D.M. Wright, T.R. Robinson, J.A. Davies, and M. Rietveld (1997), High spatial and temporal resolution observations of an impulse-driven field line resonance in radar backscatter artificially generated with the Tromsø heater, Ann. Geophys. 15, 634-644, DOI: 10.1007/s00585-997-0634-9.

Yeoman, T.K., J.A. Davies, N.M. Wade, G. Provan, and S.E. Milan (2000), Combined CUTLASS, EISCAT and ESR observations of ionospheric plasma flows at the onset of an isolated substorm, Ann. Geophys. 18, 1073-1087, DOI: 10.1007/s00585-000-1073-z.

Yeoman, T.K., M. James, P.M. Mager, and D.Y. Klimushkin (2012), SuperDARN observations of high$\mathrm{m}$ ULF waves with curved phase fronts and their interpretation in terms of transverse resonator theory, J. Geophys. Res. 117, A06231, DOI: 10.1029/2012JA017668. 


\title{
RADARY SUPERDARN - WPROWADZENIE
}

\author{
Streszczenie
}

Radary SuperDARN powstały jako narzędzie do badań górnych warstw atmosfery i ich związków z magnetosferą i wiatrem słonecznym (np. Greenwald i in. 1995, Chisham $\mathrm{i}$ in. 2008, Lester 2008, 2013). Pracują w zakresie częstotliwości HF (High Frequency), pomiędzy 8 a $20 \mathrm{MHz}$. Ich zasada działania opiera się na wykorzystaniu rozpraszania Bragga na periodycznych strukturach przestrzennych o skalach odległości porównywalnych z długością fali sondującej. Radary te umożliwiają obserwacje formacji jonosferycznych zorientowanych wzdłuż linii pola geomagnetycznego.

W pracy przedstawiono powstanie i rozwój sieci SuperDARN z uwzględnieniem działających obecnie na świecie radarów na średnich szerokościach, które są szczególnie interesujące w kontekście potencjalnej lokalizacji w Polsce.

Jedną z kluczowych kwestii przy wyborze lokalizacji dla nowopowstającej stacji SuperDARN jest określenie jej potencjalnych możliwości obserwacyjnych. Można wykorzystać do tego oprogramowanie dokonujące śledzenia dróg propagacji impulsu emitowanego przez radar i określania punktów w których wektor fali jest prostopadły do lokalnego pola magnetycznego Ziemi. Warunek taki pozwoli na uzyskanie rozproszenia wyemitowanej przez antenę radaru fali z powrotem, w kierunku nadawania.

W artykule przedstawiono wyniki symulacji dla hipotetycznej stacji SuperDARN, zlokalizowanej w południowo-zachodniej Polsce. W obliczeniach użyto programu do ray tracingu, bazującego na algorytmie Jones i Stephenson (1975), modelu jonosfery IRI-2012 (Bilitza 2014) oraz modelu pola geomagnetycznego IGRF (Thebault et al. 2015). 



\title{
Thunderstorms, \\ lightning discharges and ULF/ELF/LF radiation
}

\author{
Układy burzowe, \\ wyładowania atmosferyczne \\ i promieniowanie w pasmie \\ ULF/ELF/LF
}





\title{
Connections Between Electromagnetic Signals Generated by Mesoscale Convective Systems, Observed by an ELF Ground Station and DEMETER Satellite
}

\author{
Karol MARTYNSKI ${ }^{1, \bowtie}$, Andrzej KULAK ${ }^{1}$, Janusz MLYNARCZYK ${ }^{2}$, \\ Jan BLECKI ${ }^{2}$, Roman WRONOWSKI ${ }^{2}$, and Rafał IWANSKI ${ }^{3}$ \\ ${ }^{1}$ Department of Electronics, AGH University of Science and Technology, Cracow, Poland \\ ${ }^{2}$ Space Research Centre, Polish Academy of Sciences, Warsaw, Poland \\ ${ }^{3}$ Satellite Remote Sensing Department, Institute of Meteorology and Water Management - \\ National Research Institute, Cracow, Poland \\ karol.martynski@agh.edu.pl
}

Strong convective events in Europe are relatively regular, especially in the summer season, when there is an advection of warm tropical airmass from the southern regions. High water vapour content in the warm air, convection, atmosphere instability and strong vertical thermal gradients, are favouring development of strong storm complexes, such as MCS (Mesoscale Convective System) (Bonner 1968, Banta et al. 2002, Houze 2014). They are created by strongly developed Cumulonimbus and Nimbostratus clouds and they can cover an area up to $100000 \mathrm{~km}^{2}$. They are characterized by significant hail and naval precipitation (Chomicz 1951), strong winds, which can reach the level of $150 \mathrm{~km} / \mathrm{h}$, many atmospheric discharges and relatively long time of the occurrence, from 6 up to 12 hours (Chappell 1986). Our research on MCS will be divided into three different parts.

First part of the analysis is conducted using METEOSAT9 satellite, which allows us to identify thunderstorms using IR camera installed on board (Maddox 1980). With this setup, we will analyse the height of cloud tops, which can reach level of $15 \mathrm{~km}$. This means the penetration of the tropopause and the lower parts of the stratosphere by clouds. This is possible due to strong updrafts in the thunderstorm structure. In addition, synoptic data will be used for an analysis of thermodynamic conditions, such as CAPE, CIN, K-index, which occurred in the thunderstorm activity period. In this paper we will cover two case studies MCS on 23th of July 2009 and MCS on 24th of May 2010. The second part of the research is focused on the analysis of the thunderstorms, using the Hylaty ELF station (Kulak et al. 2014), which has been placed 
in Polish mountains in the Bieszczady region. The station is equipped with two orthogonal antennas, which allow us to detect electromagnetic signals in the ELF band (Extremely Low Frequencies). It belongs to the global system WERA (World ELF Radiolocation Array) enabling us to study signals from strong thunderstorms around the world (Mlynarczyk et al. 2017). Based on these measurements we are able to use inverse solutions, which we developed, and compute electric dipole moments of positive and negative cloud-to-ground discharges (+CG and $-\mathrm{CG})$ (Kulak and Mlynarczyk 2013, Kulak et al. 2013, Mlynarczyk et al. 2015). The last part of our studies covers the search for correlations between data from the DEMETER satellite, to the data from Hylaty station. The satellite has the ability to measure VLF (Very Low Frequencies) and ELF signals, which give us a possibility of looking for the relationship between the measurements on the orbit (Parrot et al. 2008, 2013; Błęcki et al. 2016), and ground-based measurements, and thus differences and changes in the ionosphere and magnetosphere due to thunderstorm activity (Berthelier et al. 2006). The highest activity of MCS is during evenings, which coincides with the DEMETER flybys over Europe.

This is a complex study of the interactions between atmospheric discharges and the ionosphere-magnetosphere system. Simultaneous satellite and ground measurements enable deeper analysis of these processes. We expect significant progress in understanding them and their role in the physics of the higher atmosphere. During a single discharge, the enormous energies are released and they have a huge impact on the ionosphere, causing mesoscale disturbances. It influences telecommunication and the accuracy of GPS systems (e.g. Lee and Mousa 1996), so understanding these phenomenon has a practical value.

Acknowledgments. Studies are conducted by a financial aid from National Centre of Science, Grant no. 2017/27/B/ST10/02285.

\section{References}

Banta, R.M., R.K. Newsom, J.K. Lundquist, Y.L. Pichugina, R.L. Coulter, and L. Mahrt (2002), Nocturnal low-level jet characteristics over Kansas during Cases-99, Bound.-Lay. Meteorol. 105, 2 , 221-252, DOI: 10.1023/A:1019992330866.

Berthelier, J.J., M. Godefroy, F. Leblanc, M. Malingre, M. Menvielle, D. Lagoutte, J.Y. Brochot, F. Colin, F. Elie, C. Legendre, P. Zamora, D. Benoist, Y. Chapuis, J. Artru, and R. Pfaff (2006), ICE, the electric field experiment on DEMETER, Planet. Space Sci. 54, 5, 456-471, DOI: 10.1016/j.pss.2005.10.016.

Błęcki, J., M. Parrot, J. Słomiński, M. Kościesza, R. Wronowski, and S. Savin (2016), Evolution of the ionospheric plasma turbulence over seismic and thunderstorm areas, J. Environ. Sci. Eng. A 6, 277-285, DOI: 10.17265/2162-5298/2016.06.001.

Bonner, W.D. (1968), Climatology of the low level jet, Mon. Weather Rev. 96, 12, 833-850, DOI: 10.1175/1520-0493(1968)096<0833:COTLLJ>2.0.CO;2.

Chappell, C.F. (1986), Quasi-stationary convective events. In: P.S. Ray (ed.), Mesoscale Meteorology and Forecasting, American Meteorological Society, Boston, 289-310, DOI: 10.1007/978-1935704-20-1_13.

Chomicz, K. (1951), Ulewy i deszcze nawalne w Polsce, Wiadomości Stużby Hydrologicznej i Meteorologicznej, 2, 3, 5-88.

Houze Jr., R.A. (2014), Mesoscale convective systems. In: Cloud Dynamics, Vol. 104, Chapter 9, 237 286, Academic Press. 
Kulak, A., and J. Mlynarczyk (2013), ELF propagation parameters for the ground-ionosphere waveguide with finite ground conductivity, IEEE T. Antenn. Propag. 61, 4, 2269-2275, DOI: 10.1109/ TAP.2012.2227445.

Kulak, A., J. Mlynarczyk, and J. Kozakiewicz (2013), An analytical model of ELF radiowave propagation in ground-ionosphere waveguides with a multilayered ground, IEEE T. Antenn. Propag. 61, 9, 4803-4809, DOI: 10.1109/TAP.2013.2268244.

Kulak, A., J. Kubisz, S. Klucjasz, A. Michalec, J. Mlynarczyk, Z. Nieckarz, M. Ostrowski, and S. Zieba (2014), Extremely low frequency electromagnetic field measurements at the Hylaty station and methodology of signal analysis, Radio Sci. 49, 361-370, DOI: 10.1002/2014RS005400.

Lee, H., and A.M. Mousa (1996), GPS travelling wave fault locator systems: investigation into the anomalous measurements related to lightning strikes, IEEE T. Power Deliver. 11, 3, DOI: $10.1109 / 61.517474$.

Maddox, R.A. (1980), Mesoscale convective complexes, Bull. Amer. Meteorol. Soc. 61, 11, 1374-1387.

Mlynarczyk, J., J. Bor, A. Kulak, M. Popek, and J. Kubisz (2015), An unusual sequence of sprites followed by asecondary TLE - an analysis of ELF radio measurements and optical observations, J. Geophys. Res. 120, DOI: 10.1002/2014JA020780.

Mlynarczyk, J., A. Kulak, and J. Salvador (2017), The accuracy of radio direction finding in the extremely low frequency range, Radio Sci. 52, 1245-1252, DOI: 10.1002/2017RS006370.

Parrot, M., J.J. Berthelier, J.P. Lebreton, R. Treumann, and J.L. Rauch (2008), DEMETER observations of EM emissions related to thunderstorms, Space Sci Rev. 137, 511-519, DOI: 10.1007/s11214008-9347-y.

Parrot, M., J.A. Sauvaud, S. Soula, J.L. Pinçon, and O. van der Velde (2013), Ionospheric density perturbations recorded by DEMETER above intense thunderstorms, J. Geophys. Res. - Space 118, 8, 5169-5176, DOI: 10.1002/jgra.50460.

\section{POWIĄZANIA POMIĘDZY SYGNALAMI ELEKTROMAGNETYCZNYMI WYGENEROWANYMI PRZEZ MEZOSKALOWE UKLADY KONWEKCYJNE, OBSERWOWANE PRZEZ NAZIEMNĄ STACJE ELF ORAZ SATELITE DEMETER}

\section{Streszczenie}

Silne zjawiska konwekcyjne w Europie są względnie regularne, zwłaszcza w sezonie letnim, kiedy pojawia się adwekcja ciepłego powietrza zwrotnikowego znad morza Śródziemnego. Wysoka zawartość pary wodnej w ciepłym powietrzu, konwekcja, niestabilność atmosfery oraz silny pionowy gradient termiczny, wspierają rozwój silnych klastrów burzowych, takich jak MCS (Mesoscale Convective Systems - Mezoskalowe Układy Konwekcyjne) (Bonner 1968, Banta i in. 2002, Houze 2014). Tworzą się one z silnie rozwiniętych chmur Cumulonimbus i mogą pokryć obszar nawet do $100000 \mathrm{~km}^{2}$. Charakteryzują się znacznymi opadami gradu i nawalnym typem opadu atmosferycznego (Chomicz 1951), co więcej generują silne porywy wiatru, które mogą osiągnąć prędkości przekraczające $150 \mathrm{~km} / \mathrm{h}$. Liczne wyładowania atmosferyczne i długi czas aktywności (od 6 do nawet 12 godzin) (Chappell 1986) charakteryzują te struktury burzowe. Analiza danych będzie podzielona na trzy etapy. 
Pierwsza część zostanie przeprowadzona przy użyciu satelity METEOSAT9, która pozwoli na identyfikację burz przy użyciu kamery podczerwonej zainstalowanej na jej pokładzie (Maddox 1980). Wykorzystanie tego narzędzia umożliwi pomiar wysokości wierzchołków chmur, które w przypadku MCS-ów mogą osiągnąć wysokość nawet do $15 \mathrm{~km}$. Oznacza to penetrację tropopauzy, aż do niższych warstw stratosfery. Jest to możliwe ze względu na silne prądy wznoszące w strukturze burzowej. Co więcej dane synoptyczne zostaną wykorzystane do analizy warunków termodynamicznych jakie miały miejsce podczas przejścia burzy, takie jak CAPE, CIN, czy K-index. W tej pracy dokonano analizy dwóch przypadków MCS: pierwszy z dnia 23.07.2009 oraz drugi z dnia 24.05.2010.

Druga część analizy jest skierowana na pomiary z naziemnej stacji ELF - Hylaty (Kulak i in. 2014), która znajduje się w polskich górach, w Bieszczadach. Stacja jest wyposażona w dwie ortogonalne anteny, które pozwalają na detekcję sygnałów w zakresie ELF (Extremely Low Frequencies). Stacja należy do globalnej sieci - WERA (World ELF Radiolocation Array), umożliwiającą badania nad burzami na całym świecie (Mlynarczyk i in. 2017). Opierając się na tych pomiarach wykorzystano rozwinięte w naszym zespole rozwiązania odwrotne, które pozwalają na policzenie momentów dipolowych wyładowań -CG oraz +CG (Cloud-to-Ground) (Kulak i Mlynarczyk 2013, Kulak i in. 2013, Mlynarczyk i in. 2015).

Ostatnim etapem badań jest szukanie korelacji pomiędzy danymi z satelity DEMETER, a pomiarami ze stacji Hylaty. Satelita umożliwia pomiar sygnałów w zakresie VLF (Very Low Frequencies) oraz ELF, które pozwalają na szukanie tych relacji (Parrot i in. 2008, Parrot i in. 2013, Błęcki i in. 2016). Co za tym idzie różnic i zmian w jonosferze i magnetosferze, wywołanych przez aktywność burzową (Berthelier i in. 2006). Największa aktywność MCSów występuje wieczorem, gdzie w podobnym okresie nad Europą przelatuje satelita DEMETER.

Badania te są studium nad interakcjami pomiędzy wyładowaniami atmosferycznymi, a systemem jonosfera-magnetosfera. Równocześnie pomiary satelitarne i naziemne pozwolą na głębsze analizy tych procesów. Spodziewamy się dokonać znacznego postępu w zrozumieniu tych procesów oraz ich znaczenia w fizyce górnych warstw atmosfery. Podczas pojedynczego wyładowania, uwalniane są potężne ilości energii, które mają ogromny wpływ na jonosferę, powodując mezoskalowe zaburzenia. Ma to wpływ na telekomunikację, dokładność systemów GPS (np. Lee i Mousa 1996), w związku z tym zrozumienie tych procesów ma znaczenie praktyczne. 


\title{
Electric Structure of Multiple Cloud-to-Ground Flashes Obtained from the Local Lightning Detection Network Recordings During Thunderstorm in the Warsaw Region on 25 May 2018
}

\author{
Piotr BARAŃSKI ${ }^{1, \bowtie}$ \\ ${ }^{1}$ Institute of Geophysics Polish Academy of Sciences, Warsaw, Poland \\ $\triangle$ baranski@igf.edu.pl
}

\section{INTRODUCTION}

The occurrence of multiple Cloud-to-Ground (CG) flash incident is a manifestation of the complex electric charge space configuration existing in the bottom layer of a thundercloud. Thus, if we are able to evaluate the 3D location and the amount of the electric charge $\mathrm{Q}$, involved in the particular component of this lightning discharge, i.e., the return stroke or the continuing current stage, from our multi-station E-field recordings on the ground (at least in four distant locations), then it is possible to have an insight into how such electric structure of the particular thundercloud region favorable for lightning initiation is built. Sometimes these multiple CG flashes are grouped in repeated episodes in short time intervals, e. g., from a few to several minutes, what can inform us about the time changes of the electric charge space redistribution in this thundercloud region. More detail and general information on multiple CG flashes is given for example in Table 1.1 in Rakov and Uman (2003, Ch. 1, p. 7).

\section{MEASUREMENT SET-UP AND RESULTS}

The four Local Lightning Detection Network (LLDN) stations were located at different and distant places in the Warsaw region and were used to record the E-field signatures of lightning discharges during the field thunderstorm measurement campaign in 2018. This network configuration is shown in Fig. 1, and the exemplary general view of one LLDN station is given in Fig. 2. Using only four of the LLDN stations we were able to find the four searched parameters, i.e., three space coordinates $\mathrm{x}, \mathrm{y}, \mathrm{z}$ and the electric charge $\mathrm{Q}$ involved in the particular lightning stroke. However, we cannot assess the errors of such particular solution. In order to do error evaluation we should use more than four LLDN stations for our E-field recordings and this was impossible for us in the 2018 season campaign. The full error analysis of the best search solution in the case when we have to disposal six LLDN stations located at different places in the Warsaw region is given by Baranski et al. (2011). This paper also contains more detailed description of our LLDN recording system performance and its calibration. 


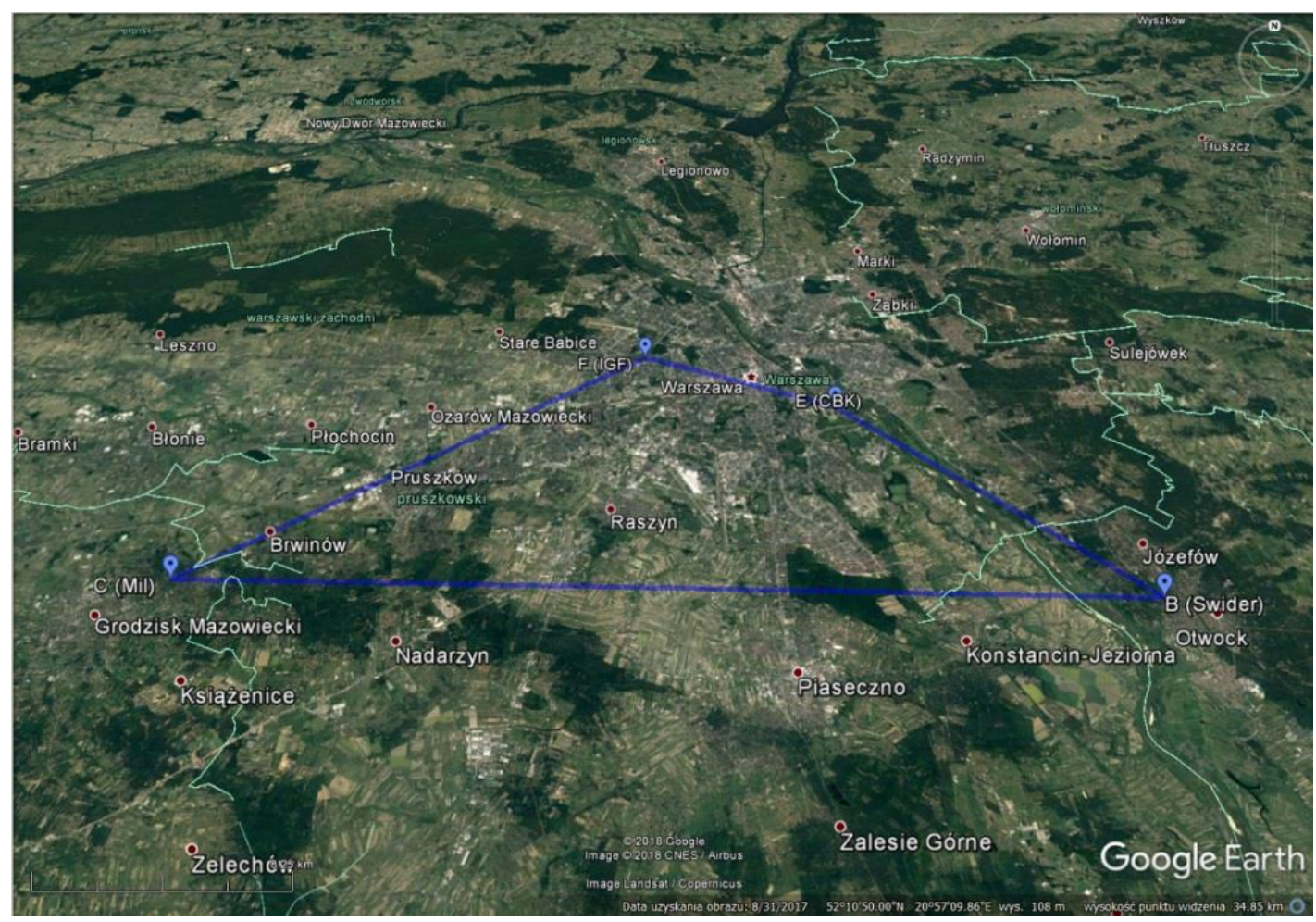

Fig. 1. The locations of four LLDN stations in the Warsaw region during field thunderstorm measurement campaign in 2018. The distances between particular LLDN stations are: LLDN-C(Milanówek) LLDN-F(IGF) 23 km, LLDN-F(IGF) - LLDN-E(CBK) 9.4 km, LLDN-E(CBK) - LLDN-B(Świder) 16 km, LLDN-C(Milanówek) - LLDN-B(Świder) 39.1 km. Satellite map from Google Earth.

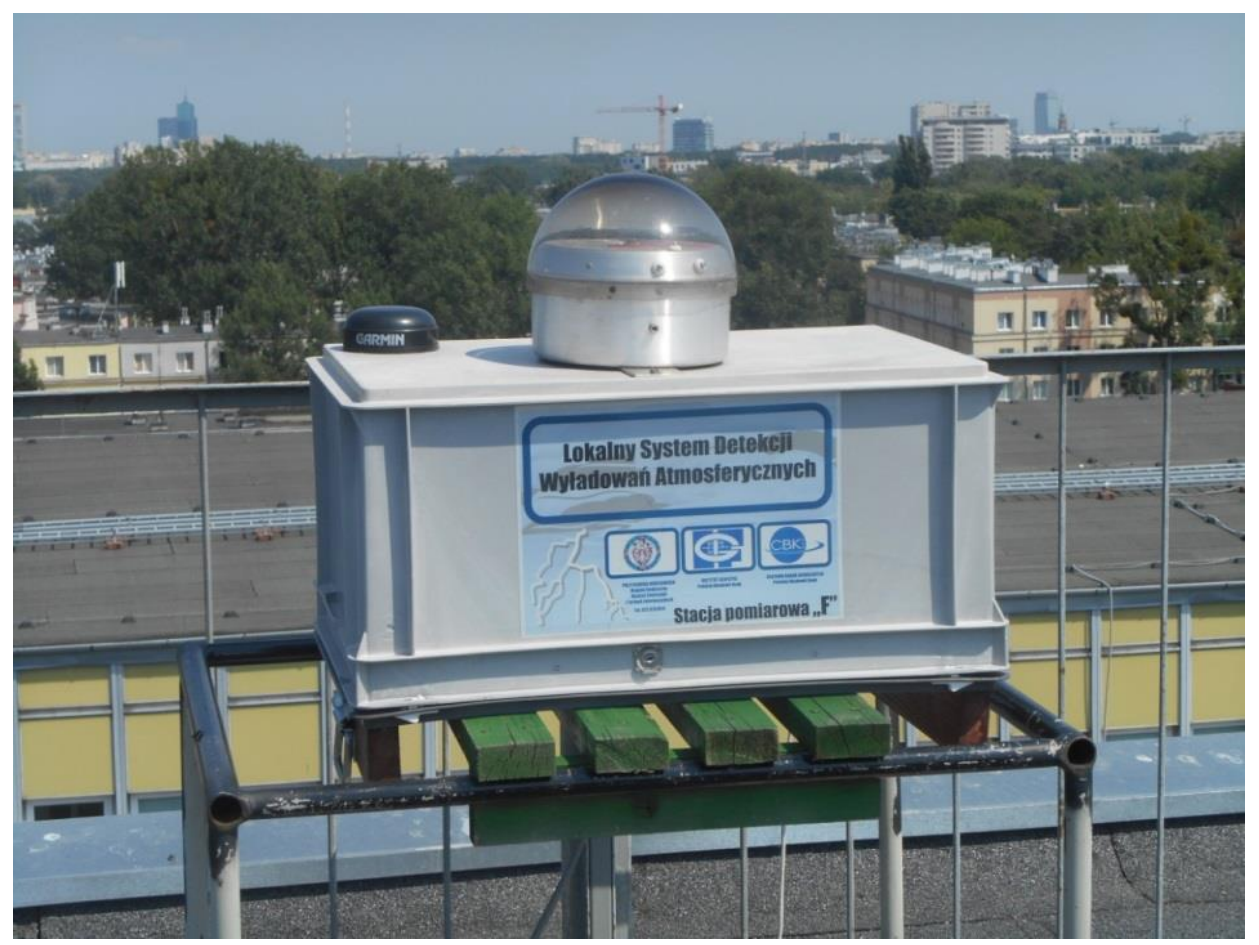

Fig. 2. The general view of LLDN-F(IGF) station located at the roof of IG PAS building. The GPS Garmin receiver and E-field antenna sensor mounted on the top of the grey box with the A/D recorder and the power supply buffer inside. 
The selected three exemplary incidents of multiple CG flashes retrieved from the thunderstorm episode in the Warsaw region on 25 May 2018 are given in Figs. 3a-3c.

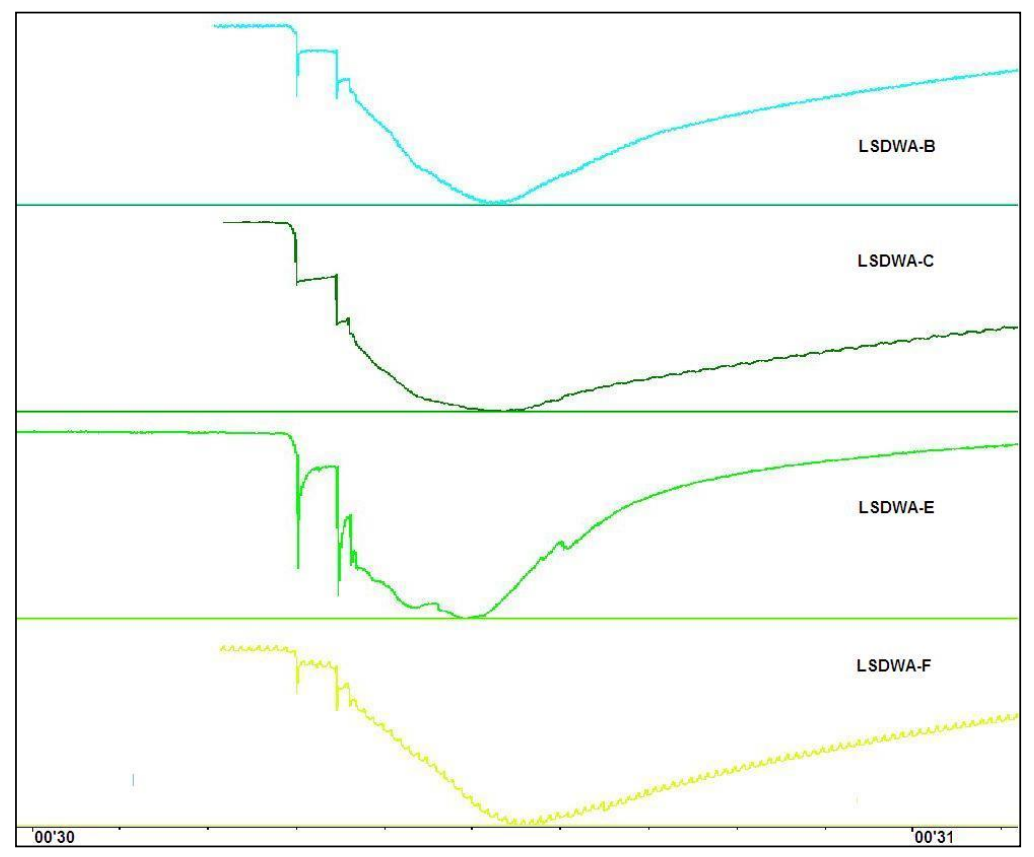

Fig. 3a. The E-field signatures of a multiple negative CG flash simultaneously recorded by four LLDN stations. This CG flash was recorded at 11:00:30 UT and consisted of three return strokes ending with continuing current stage, and lasted $0.21 \mathrm{~s}$.

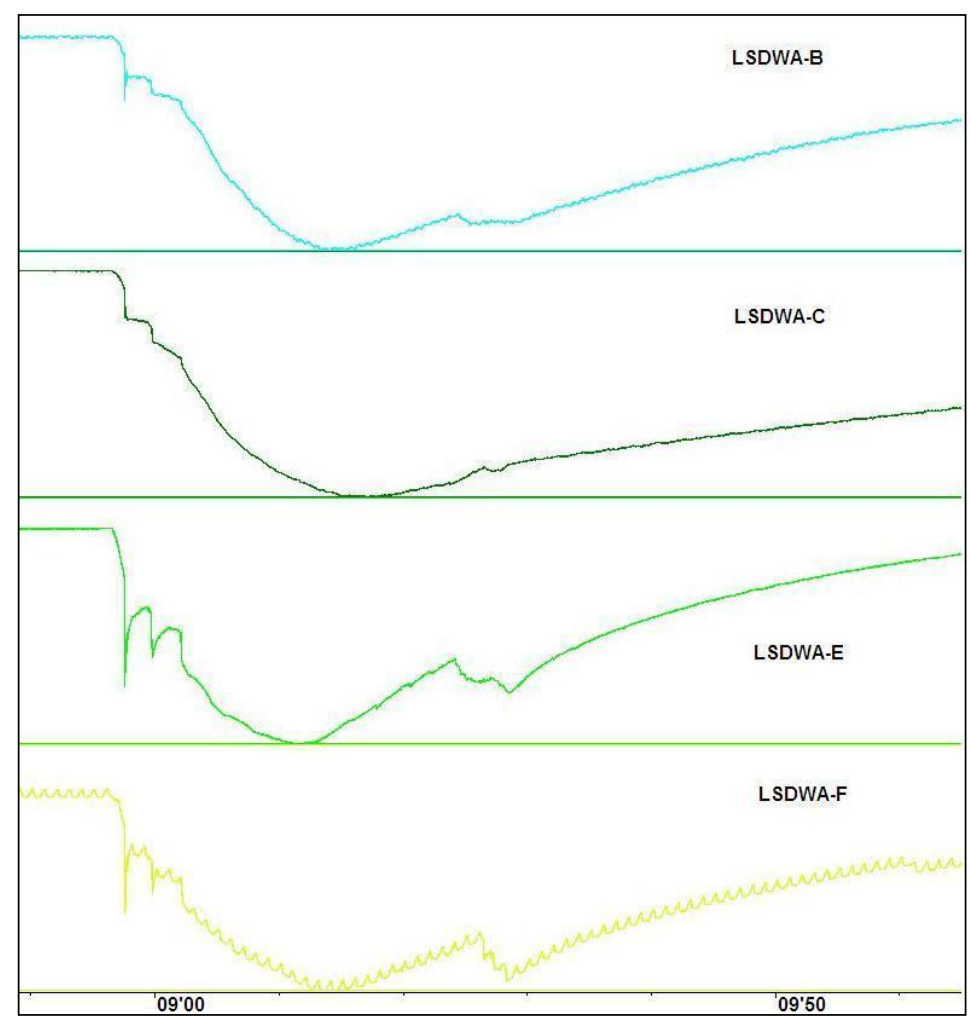

Fig. 3b. The same as in Fig. 3a, except the time occurrence at 11:03:08 UT. This multiple CG flash lasted $0.25 \mathrm{~s}$. 


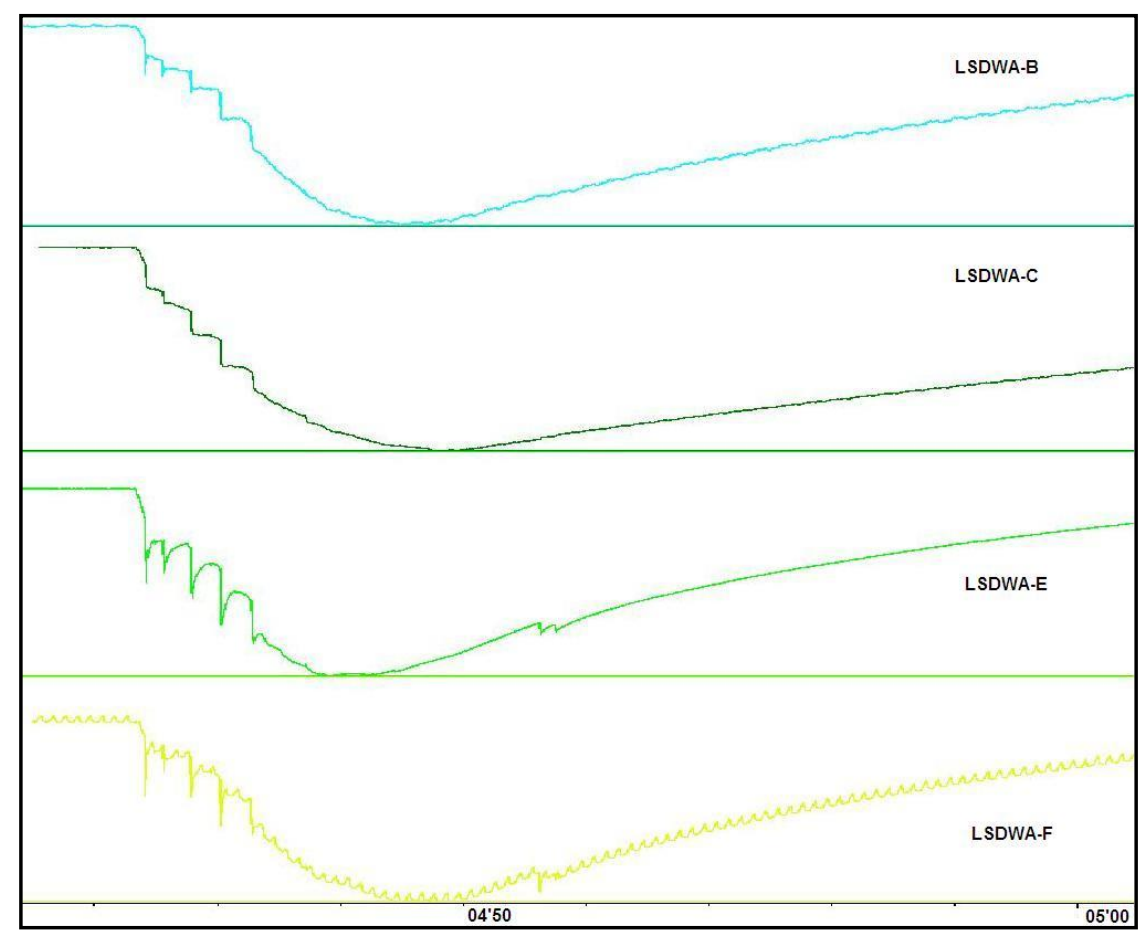

Fig. 3c. The same as in Fig. 3a, except the time occurrence at 11:04:04 UT and the flash multiplicity. This multiple CG flash consisted of five return strokes also ending with continuing current stage, also lasted $0.25 \mathrm{~s}$.

The thunderstorm episode in the Warsaw region on 25 May 2018 was characterized by significant and frequent initiations of multiple CG flashes. During the time interval from 11:00:30 to 11:14:15 UT the LLDN stations detected 11 such CG flash incidents (see Table 1).

The 3D location and electric charge amount of lightning stroke sources for the three considered multiple CG flashes during the thunderstorm episode in the Warsaw region 25 May 2018 are presented in Figs. $4 \mathrm{a}-4 \mathrm{c}$.

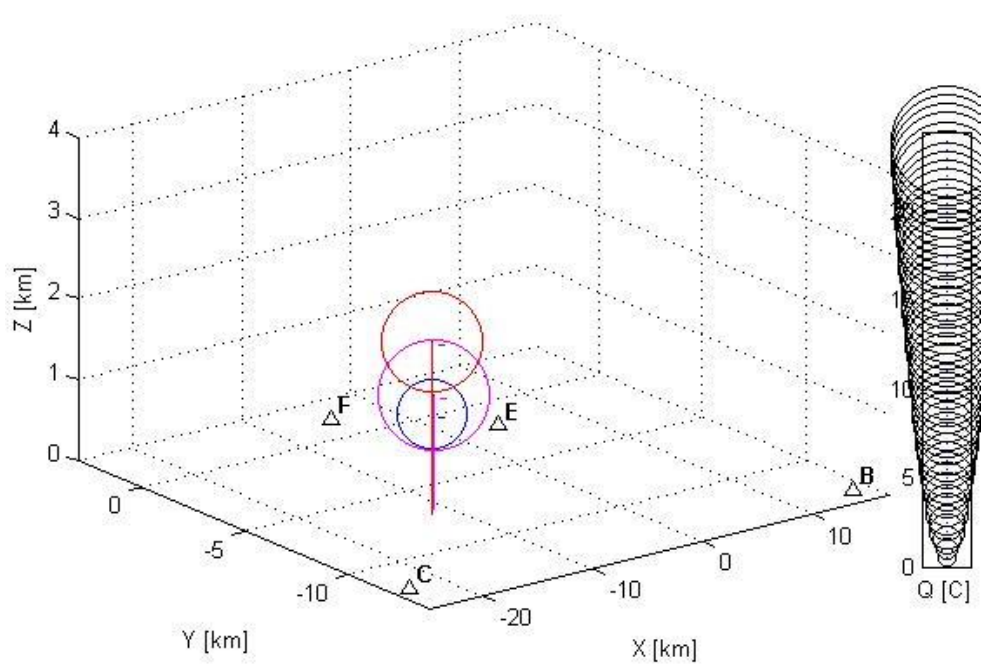

Fig. 4a. The (x, y, z, Q) parameters for three return strokes involved in the multiple CG flash recorded at 11:00:30 UT; the first stroke indicated by red color, the second by magenta color, and the third one by blue color. These strokes discharged the total electric charge of $-51.5 \mathrm{C}$ in the thundercloud. The small triangle with big letter B, C, E, and F indicates the plane location of the particular LLDN station. 


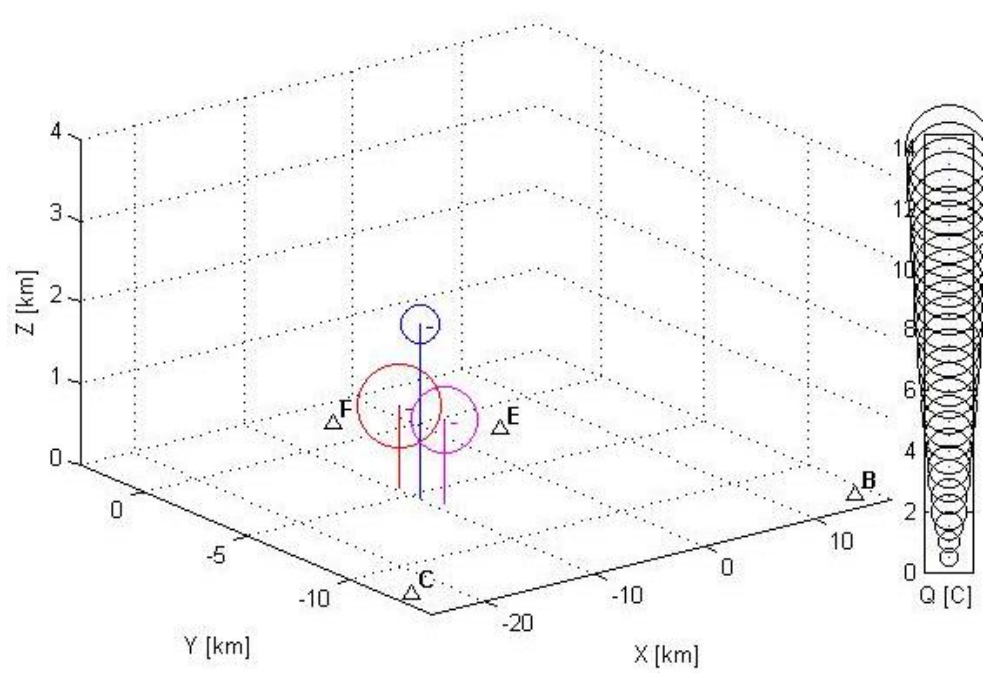

Fig. 4b. The same as in Fig. 4a, except the time occurrence of the multiple CG flash at 11:03:08 UT. Here, the three strokes discharged the total electric charge in the thundercloud equal to $-24.7 \mathrm{C}$.

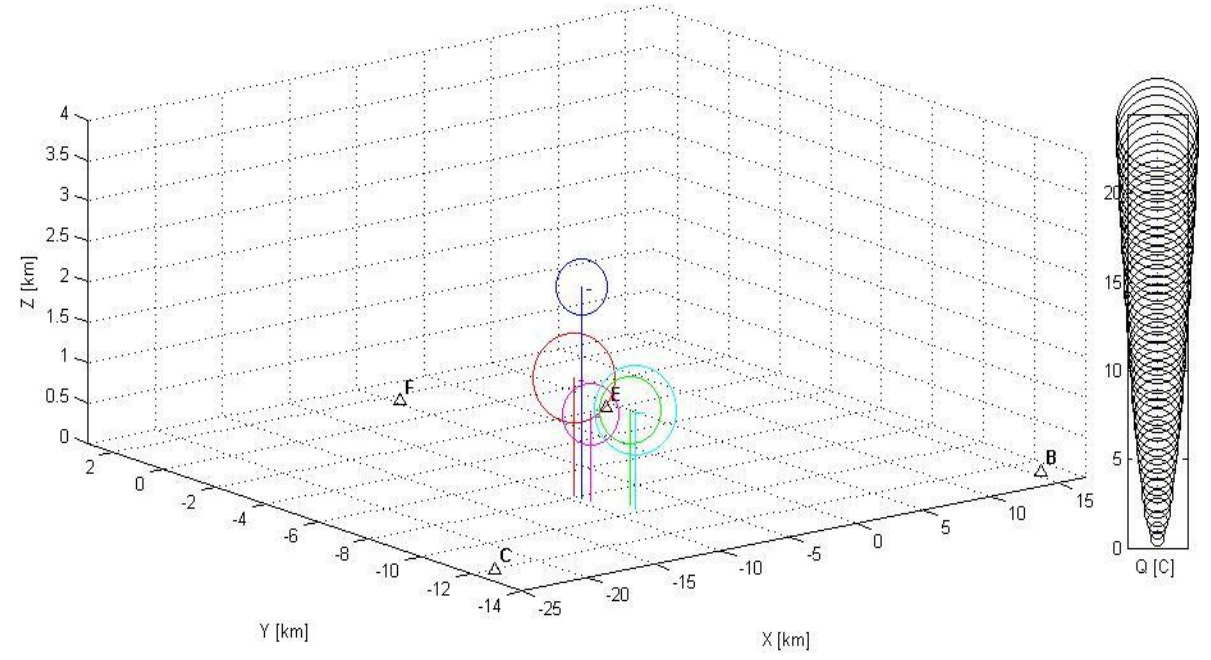

Fig. 4c. The same as in Fig. 4a, except the time occurrence at 11:04:04 UT and multiplicity of this CG flash. It consists from 5 return strokes. The first stroke is indicated by red color, the second by magenta color, the third by blue color, the fourth by cyan color, and the fifth one by green color. Here, these five strokes discharged the total electric charge in the thundercloud equal to $-79.2 \mathrm{C}$.

Having the $(\mathrm{x}, \mathrm{y}, \mathrm{z})$ parameters for each charge source that was involved in the particular return stroke of the considered multiple CG flashes we can overlap them on the relevant in time PCAPPI/plane return stroke positions and VCUT/vertical return stroke positions radar maps. In this way we can distinguish such thundercloud regions where there were favorable conditions for the development/initiation of the considered multiple CG flashes. These superpositions are shown below in Figs.5a-5c and Figs.6a-6c, respectively.

It is worth noting that all electric charge source locations of the considered return strokes involved in multiple CG flashes overlapped on the PCAPPI and VCUT radar maps (see Figs. 5a-5c and Figs. 6a-6c) are collocated with the intense core of precipitation shaft at the base of the thundercloud. It could mean that the large amount of negative electric charge in this thundercloud layer is deposited on big highly charged cloud particles that later on are giving gush rain at the ground. The most frequent occurrence of multiple CG flashes was recorded 


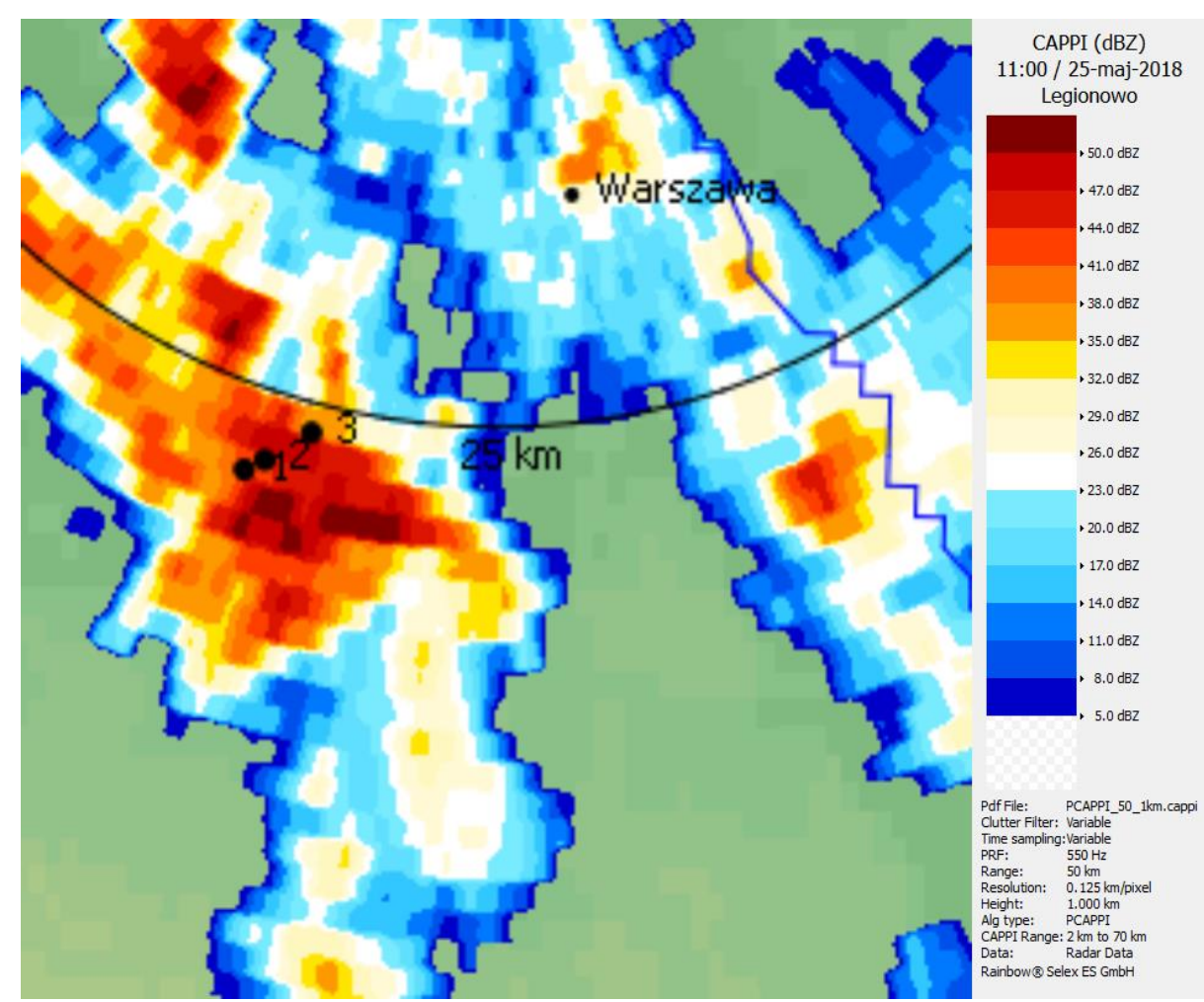

Fig. 5a. The plain locations of three return strokes from the multiple CG flash recorded at 11:00:30 UT and overlapped on the PCAPPI radar map from 11:00 UT. Here, radar data are taken from the meteorological radar (METEOR 1500C) at Legionowo station and operated by the IMWM-NRI.

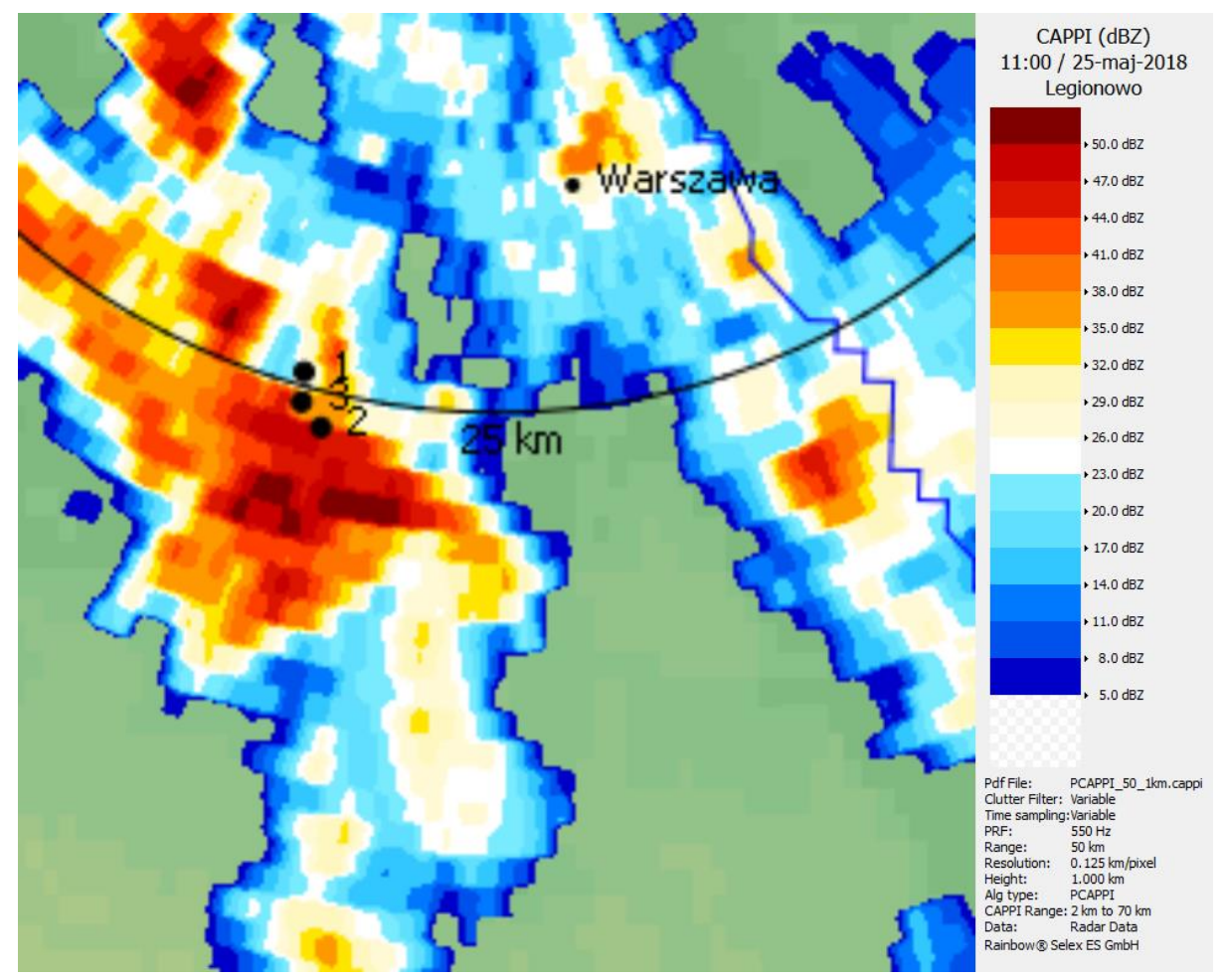

Fig. 5b. The same as in Fig. 5a, except the time occurrence of multiple CG flash at 11:03:08 UT. 


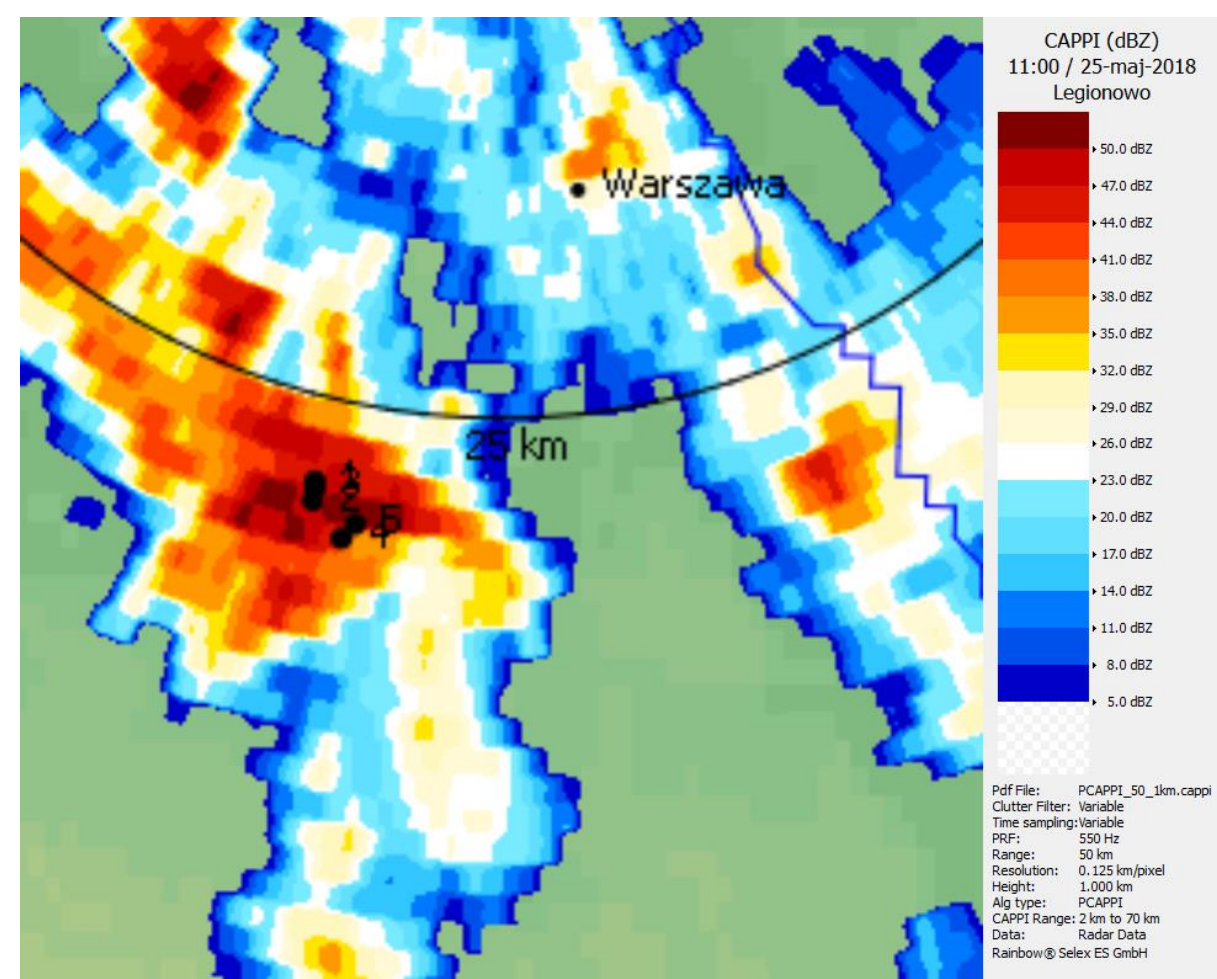

Fig. 5c. The same as in Fig. 5a, except the time occurrence at 11:04:04 UT and multiplicity of this CG flash.

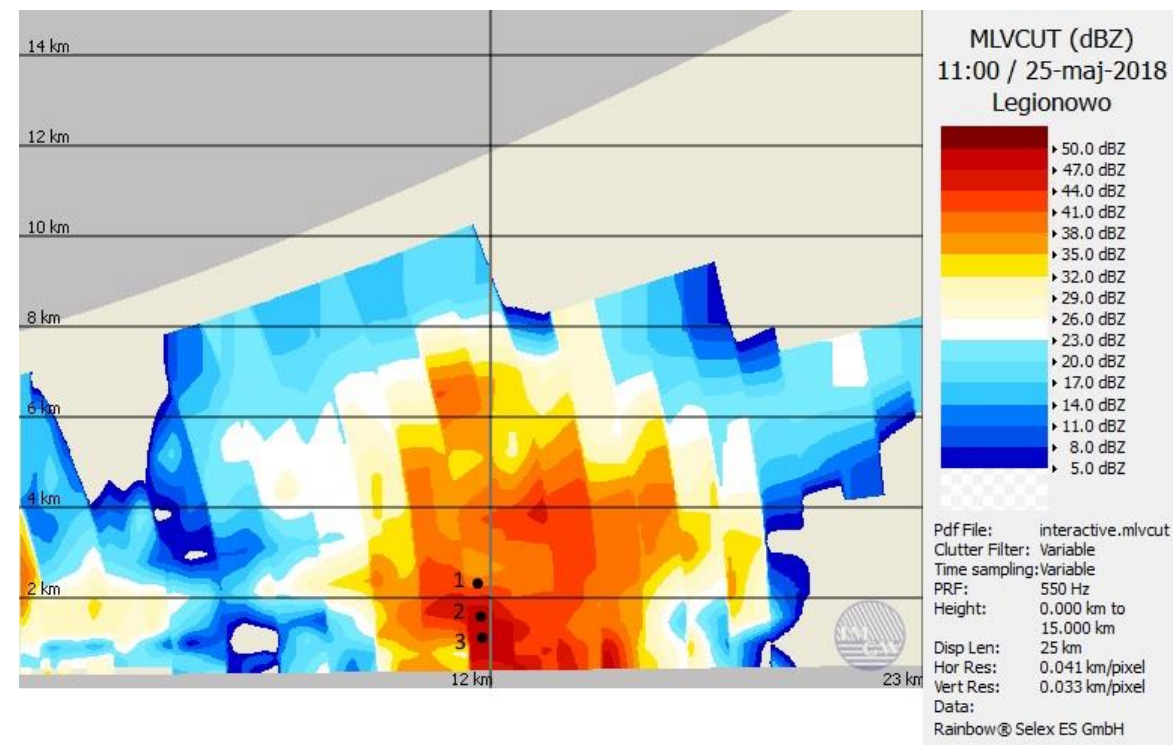

Fig. 6a. The height of the particular return stroke electric charge source of multiple CG flash recorded at 11:00:30 UT and overlapped on the VCUT radar map from 11:00 UT. Here, this height is equal to $1.5,1.1$ and $1.2 \mathrm{~km}$, respectively. The radar data are taken from the meteorological radar (METEOR 1500C) at Legionowo station and operated by the IMWM-NRI.

during the thundercloud dissipation stage and lasted from 11:00 to 11:15 UT. In this time period we were able to distinguish eleven such lightning discharge incidents using our LLDN data in the post-time analysis. These CG flashes are listed together in Tab. 1. It is worth noting that 


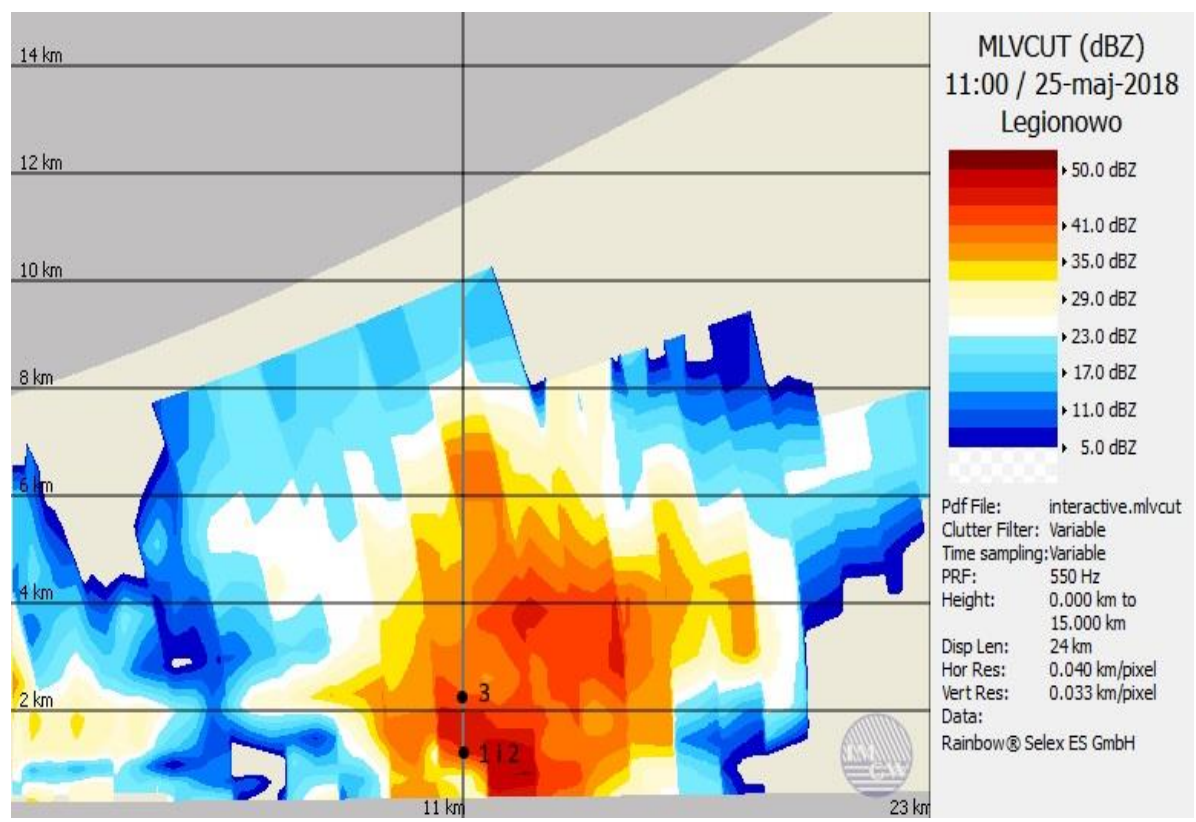

Fig. 6b. The same as in Fig. 6a, except the time occurrence of multiple CG flash at 11:03:08 UT and with the height of stroke sources at 1.0, 1.0 and $2.1 \mathrm{~km}$, respectively.

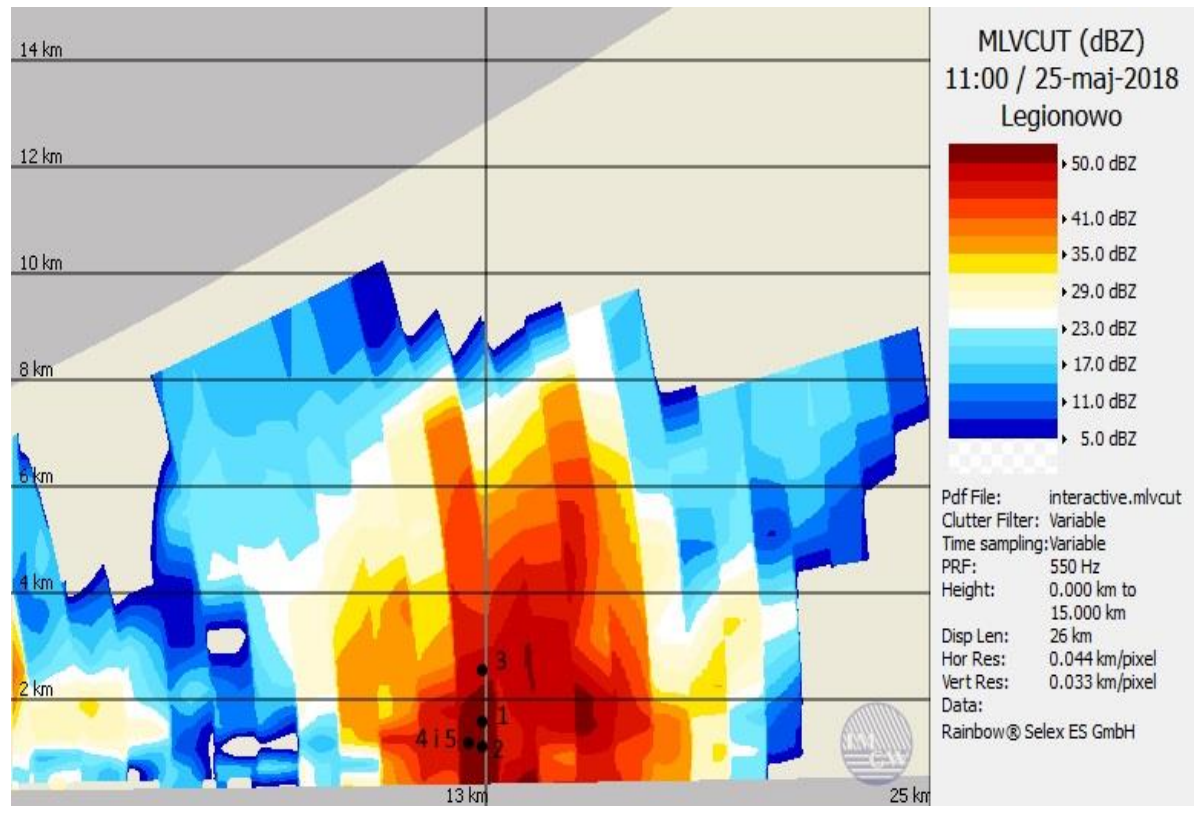

Fig. 6c. The same as in Fig. 6a, except the time occurrence at 11:04:04 UT and multiplicity of this CG flash. Here, the height of stroke sources is equal 1.5, 1.1, 2.6, 1.2 and $1.2 \mathrm{~km}$, respectively.

although we had not possibility of using the fifth redundant LLDN station allowing us for calculation of errors of the searched quantities ( $\mathrm{x}, \mathrm{y}, \mathrm{z}$ and $\mathrm{Q}$ ), we can in the end, make a coarse assumption that for each return stroke we find its plane location as an independent observation that should indicate similar plane coordinates, i.e., $\mathrm{x}$ and $\mathrm{y}$ for successive impacts in a multiple CG discharge. Such a coarse assumption can of course not be extended to its $\mathrm{z}$ and $\mathrm{Q}$ component. But, analysing the values of $\Delta \mathrm{d}$ given in Tab. 1 , we can note that for the majority of cases obtained the results are satisfactory and $\Delta \mathrm{d}$ is less than a few $\mathrm{km}$. 
Table 1

The general characteristic of eleven multiple CG flash incidents distinguished from the LLDN data during thunderstorm in the Warsaw region on 25 May 2018

\begin{tabular}{|c|c|c|c|c|c|}
\hline $\begin{array}{c}\text { No. multiple CG flash } \\
\text { (order and type of its strokes); } \\
\text { time of occurrence of .dat file [UT] }\end{array}$ & \begin{tabular}{|c|} 
Time interval between \\
subsequent strokes \\
{$[\mathrm{ms}]$}
\end{tabular} & $\begin{array}{c}\Delta \mathrm{d} \\
{[\mathrm{km}]}\end{array}$ & $\begin{array}{c}\Delta \mathrm{z} \\
{[\mathrm{km}]}\end{array}$ & $\begin{array}{l}\mathrm{Q}_{\text {total }} \\
{[\mathrm{C}]}\end{array}$ & Range of $\chi^{2}$ \\
\hline $\begin{array}{c}\# 1(1 \mathrm{RS}-, 2 \mathrm{RS}-, \text { 3RS\&CC-); } \\
\text { 11:00:30 }\end{array}$ & $45.2 ; 15$ & 2.6 & 1.1 & -51.5 & $5.4 \div 8.3$ \\
\hline $\begin{array}{c}\text { \#2(1RS-,2RS-, 3RS\&CC-); } \\
\text { 11:03:08 }\end{array}$ & $22 ; 24$ & 1.5 & 1.1 & -24.7 & $2.9 \div 7.2$ \\
\hline $\begin{array}{c}\text { \#3(1RS-, } 2 \text { RS-, 3RS- } \\
\text {,4RS,5RS\&CC); } \\
\text { 11:04:04 }\end{array}$ & $14.4 ; 22.4 ; 24 ; 26$ & 1.9 & 1.5 & -79.2 & $0.35 \div 3.5$ \\
\hline $\begin{array}{c}\text { \#4(1RS-,2RS\&CC-); } \\
\text { 11:08:19 }\end{array}$ & 19.2 & 0.6 & 0.6 & -30.7 & $5.8 \div 9.3$ \\
\hline $\begin{array}{c}\text { \#5(1RS-,2RS-); } \\
\text { 11:12:05 }\end{array}$ & 28 & 2.7 & 0.8 & -27.3 & $0.003 \div 0.04$ \\
\hline $\begin{array}{c}\text { \#6(1RS-,2RS\&CC-); } \\
\text { 11:12:05 }\end{array}$ & 18 & 14.3 & 0.1 & -24.1 & $0.07 \div 16.3$ \\
\hline $\begin{array}{c}\text { \#7(1RS-,2RS-); } \\
\text { 11:12:57 }\end{array}$ & 40 & 8.2 & 0.8 & -40.5 & $0.004 \div 0.11$ \\
\hline $\begin{array}{c}\text { \#8(1RS-,2RS-,3RS-,4RS-); } \\
\text { 11:12:57 }\end{array}$ & $28 ; 44 ; 48$ & 15.3 & 3.1 & -36.4 & $0.007 \div 0.44$ \\
\hline $\begin{array}{c}\# 9(1 \mathrm{RS}-, 2 \mathrm{RS}-) \\
11: 12: 57 \\
\end{array}$ & 56.5 & 4.1 & 5.0 & -20.3 & $0.002 \div 0.1$ \\
\hline $\begin{array}{c}\text { \#10(1RS-,2RS-,3RS-); } \\
11: 14: 15\end{array}$ & $16 ; 22$ & 10.2 & 0.9 & -30.8 & $0.04 \div 4.4$ \\
\hline $\begin{array}{c}\text { \#11(1RS-,2RS-,3RS,4RS,5RS); } \\
11: 14: 15\end{array}$ & $42 ; 44 ; 88 ; 72$ & 16.9 & 3.0 & -80.6 & $0.03 \div 0.11$ \\
\hline
\end{tabular}

The maximal and minimal value of the particular parameter is marked by blue and green color, respectively. The abbreviation RS stands for return stroke, the CC stands for continuing current, $\Delta \mathrm{d}$ denoted horizontal extent of multiple CG flash and $\Delta z$ denotes its vertical extent. The range of $\chi^{2}$ value determines the best fit for the found particular location of return stroke electric charge source from four different optimization procedures, i.e., the accurate grid search procedure, the downhill simplex procedure and two kind of the annealing procedures, using in the post-time analysis of our LLDN data. The relevant literature references of used optimization procedures are given in Baranski et al. (2011).

\section{CONCLUSIONS AND FINAL REMARKS}

The lightning data delivered by the LLDN can be used in the post-time processing to reliable evaluation of the electric structure of multiple CG flashes by giving their important stroke parameters, i.e., the exact time occurrence up to $1 \mu \mathrm{s}$, 3D location and the amount of electric charge discharged by the particular stroke. On the other hand, the E-field signatures of such flashes that are recorded in the radio VLF range and are archived in the recorder memory buffer and are covering all time development of the considered CG lightning discharges, i.e., from the early preliminary breakdown, the stepped leader stage and the return stroke sequence with ending continuing current phase. Such comprehensive presentation and documentation of these CG lightning events cannot be obtained from any lightning location systems routinely operated in large scale in Poland, e.g., the Polish PERUN or the German LINET system. 
It is worth noting that the LLDN lightning data superimposed in the same time on the PCAPPI and VCUT radar maps can indicate these thundercloud regions that are favorable for initiation of multiple CG flashes.

Any kind of supplementary lightning data connected with initiation of multiple CG flashes are very desired to ensure relevant lightning protection of the urban high rise buildings, especially in the Warsaw region.

Acknowledgments. This work was partially supported within statutory activities grant No. 3841/E-41/S/2019 of the Ministry of Science and Higher Education of Poland. I also express my gratitude to Wojciech Gajda from the IMWM-NRI for preparing the relevant radar maps with superposition of the particular return stroke source locations obtained from the LLDN data.

References

Baranski, P., M. Loboda, J. Wiszniowski, and M. Morawski (2011), Evaluation of multiple ground flash charge structure from electric field measurements using the local lightning detection network in the region of Warsaw, Atmos. Res. 117, 99-110, DOI: 10.1016/j.atmosres.2011.10.011.

Rakov, V.A., and M.A. Uman (2003), Lightning. Physics and Effects, Cambridge University Press.

\section{STRUKTURA ELEKTRYCZNA DOZIEMNYCH WYLADOWAŃ WIELOKROTNYCH NA PODSTAWIE ICH DETEKCJI W SIECI POMIAROWEJ LSDWA W REJONIE WARSZAWY PODCZAS BURZY 25-05-2018 R.}

\section{Streszczenie}

W pracy przedstawiono wyniki lokalizacji przestrzennej (we współrzędnych lokalnego i prostokątnego układu kartezjańskiego: $\mathrm{x}, \mathrm{y}, \mathrm{z}$ ) oraz polarność i ładunek elektryczny wszystkich źródeł w chmurze burzowej, rozładowywanych przez poszczególne udary piorunowe w czasie wybranych wielokrotnych wyładowań doziemnych podczas burzy w rejonie Warszawy 25-052018. Zmiany pola elektrycznego tych wyładowań zostały zarejestrowane jednocześnie przez cztery stacje pomiarowe systemu LSDWA (Lokalny System Detekcji Wyładowań Atmosferycznych) rozmieszczone w rejonie Warszawy, w sezonie wiosenno-letnim 2018 r. Analiza „post-time” zgromadzonych cyfrowych rekordów pomiarowych została przeprowadzona w oparciu o własne algorytmy obliczeniowe, opisane szczegółowo w artykule (Baranski i in. 2011). Jedenaście rozpatrywanych doziemnych wyładowań wielokrotnych wystąpiło w czasie dyssypacji komórki burzowej, a lokalizacje przestrzenne źródeł ich ładunku elektrycznego zostały naniesione na skorelowane czasowo mapy radarowe (PCAPPI oraz VCUT), uzyskane z radaru IMGW-PIB w Legionowie. To nałożenie wskazało, że sprzyjającym obszarem chmury burzowej, w którym dochodziło do inicjacji tych wielokrotnych wyładowań doziemnych, był rejon silnej odbiciowości radarowej (powyżej $40 \mathrm{dBz}$ ) rdzenia opadowego, nisko położonego w postawie chmury. Zbiorcza charakterystyka 11-stu rozpatrywanych doziemnych wyładowań wielokrotnych z burzy 25-05-2018 r. została przedstawiona w Tabeli 1. 


\title{
First Detection of Spectral Resonance Structures of the lonospheric Alfvén Resonance in ULF/ELF Magnetic Field Recorded at Suwałki, Poland
}

\author{
Anna ODZIMEK $^{1, \bowtie}$ and Mariusz NESKA ${ }^{1}$ \\ ${ }^{1}$ Institute of Geophysics, Polish Academy of Sciences, Warsaw, Poland \\ $\triangle$ aodzimek@igf.edu.pl
}

\section{INTRODUCTION}

The ionospheric Alfvén resonance (IAR) results from the resonant interference of the shear mode of the magnetohydrodynamic Alfvén waves in a cavity created by the bottom conductive ionosphere in the E-layer and by the gradient of the mass density in the Earth's ionospheric upper F-layer (Polyakov and Rapoport 1981), where the waves are partly reflected. The eigenfrequencies of the resonance depend on the parameters of the Alfvén speed profile in the $\mathrm{F}$ layer, proportionally dependent to the ambient geomagnetic field, and inversely proportional to the square root of mass density. The parameter defining the resonance frequencies is a parameter called the IAR frequency scale, $\Delta \mathrm{f}$, which is also in approximation equal to the interval between first modes:

$$
\Delta \mathrm{f}=\mathrm{v}_{\mathrm{AF}} / 2 \mathrm{~h}=\mathrm{B}_{0} /\left[2 \mathrm{~h}\left(\mu_{0} \rho_{\mathrm{F}}\right)^{1 / 2}\right]
$$

where $\mathrm{v}_{\mathrm{AF}}$ is the minimum Alfvén speed, i.e. approximately at the mass maximum, in F-layer, $\mathrm{h}$ - geometric dimension defined by thickness of the maximum and the spatial scale of the decrease of the density above, $\mathrm{B}_{0}$ is the geomagnetic field, $\rho_{\mathrm{F}}$ - maximum F-layer plasma (ion) mass density, $\mu_{0}$ - magnetic permeability of free space.

The Alfvén ionospheric resonant modes transmit through the bottom ionosphere down to the ground creating the so called IAR spectral resonance structures, or IAR SRS (Belyaev et al. 1987), which are characterised by similar resonance frequency pattern. The resonances can be observed in the natural ULF/ELF (ultra low and extremely low frequency) electromagnetic noise in the range from one half to several $\mathrm{Hz}$, at both middle, low and high latitudes on the globe (e.g. Yahnin et al. 2003, Molchanov et al. 2004, Bösinger et al. 2002, Semenova et al. 2005, Odzimek et al. 2006). Multiple sources have been considered for the excitation of the resonances which include atmospheric and magnetospheric sources: lightning and thunderstorm activity, neutral winds, magnetospheric phenomena (Belyaev et al. 1989, Lysak 1991, Fedorov et al. 2006). 


\section{MAGNETIC OBSERVATIONS IN ULF/ELF FREQUENCY RANGE IN SUWALKI REGION}

Measurements of the magnetic horizontal components of electromagnetic natural background in the ULF/ELF frequency range have been carried out at Suwałki region (54.012 N, 23.183 E, $\mathrm{L}=2.47$ ) since mid-June 2016. The "Suwałki" site is located in the National Park of Wigry (Wigierski Park Narodowy) and thus is relatively far from anthropogenic infrastructure and relatively clean in terms of artificial electromagnetic noise.

The measurement set-up consists of two induction coils for each horizontal component, placed in N-S and E-W directions, and an ASR 01/2004 console manufactured in early 2000' in Belsk Observatory of the Geophysical Institute PAS, along with a 24-bit NDL data logger. The sampling frequency is $100 \mathrm{~Hz}$. The filter characteristics pass frequencies from 0.1 to $35 \mathrm{~Hz}$ (Neska et al. 2019). The measurements have been carried previously at Belsk for the purpose of research investigation of the Schumann Resonance (Neska and Sátori 2006).

\section{IAR SRS DETECTION IN THE ULF/ELF MAGNETIC FIELD AT SUWAŁKI}

In search of the signatures of the ionospheric Alfven resonance in the magnetic ULF/ELF data from Suwałki we have initially analysed the first month of observations made over June-July 2016.

The spectral analysis of the magnetic signal have been carried out in accordance with the method used for example in Odzimek et al. (2006), i.e. using Fourier transforms of 5-min time series divided into smaller sections of 2048 samples (equivalent to $20.5 \mathrm{~s}$ ). The shorter series are Fast-Fourier-transformed and windowed using a Hamming window. A power spectrum is next calculated as an incoherent average of the transforms (Lyons 2000) and with 50\% overlap of the data input to FFT. Then, each average power spectrum of 5-min intervals - starting from 15 UT of the day, is denoted by amplitude-coloured pixels (one pixel per one FFT point) and assembled into 24-hour spectrograms in frequency range up to $5 \mathrm{~Hz}$.

An example of such spectrogram which features visually recognised spectral resonance structures of the IAR is shown in Fig. 1. In this case, on 16/17 July 2016, the SRS IAR can be

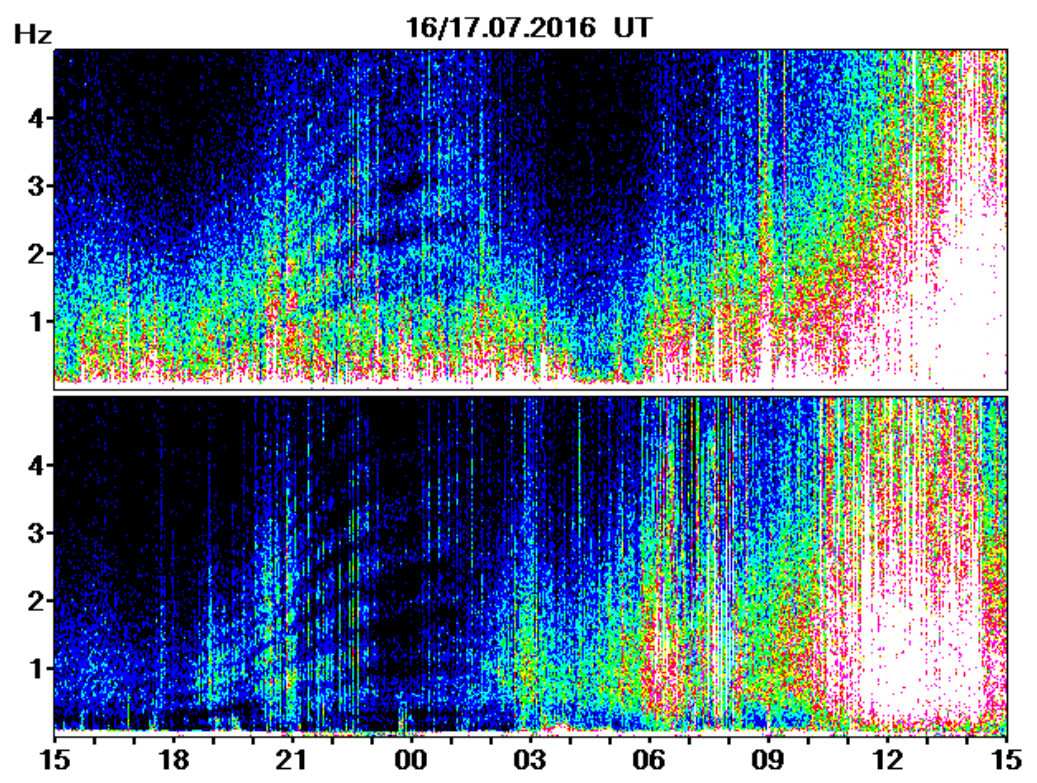

Fig. 1. Example of SRS IAR in the magnetic ULF/ELF signal observed at "Suwałki" site on 16/17 July 2016. The spectral resonance structures are seen in the power spectra of the magnetic components registered by both antennas (N-S upper panel, E-W bottom panel). The increase of the spectral amplitude at mid-day is likely due to local thunderstorm activity. An arbitrary logarithmic scale is used. 
Table 1

Summary of SRS IAR detection from June $18^{\text {th }}$ to July $16^{\text {th }}$, 2016, at "Suwałki" site, Poland

\begin{tabular}{|c|c|c|c|c|}
\hline $\begin{array}{c}\text { Date - period of } \\
24 \mathrm{~h} \text { from } 15 \mathrm{UTC}\end{array}$ & $\begin{array}{l}\text { SRS IAR in N-S } \\
\text { antenna* }\end{array}$ & $\begin{array}{l}\text { SRS IAR in E-W } \\
\text { antenna* }\end{array}$ & $\begin{array}{l}\text { Onset time } \\
\text { UT }\end{array}$ & $\begin{array}{c}\text { Ending time } \\
\text { UT }\end{array}$ \\
\hline \multicolumn{5}{|l|}{$2016 / 06 / 18$} \\
\hline $2016 / 06 / 19$ & + & + & $19: 30$ & 23:00 \\
\hline $2016 / 06 / 20$ & & $x$ & & \\
\hline $2016 / 06 / 21$ & & + & 18:00 & 04:00 \\
\hline $2016 / 06 / 22$ & & + & 19:00 & 01:00 \\
\hline $2016 / 06 / 23$ & & + & 19:00 & 01:00 \\
\hline $2016 / 06 / 24$ & $x$ & $x$ & & \\
\hline \multicolumn{5}{|l|}{$2016 / 06 / 25$} \\
\hline \multicolumn{5}{|l|}{$2016 / 06 / 26$} \\
\hline $2016 / 06 / 27$ & & $x$ & & \\
\hline $2016 / 06 / 28$ & & + & 19:00 & $23: 00$ \\
\hline $2016 / 06 / 29$ & & + & 18:00 & $00: 00$ \\
\hline $2016 / 06 / 30$ & & $x$ & & \\
\hline 2016/07/01 & $x$ & $x$ & & \\
\hline \multicolumn{5}{|l|}{$2016 / 07 / 02$} \\
\hline 2016/07/03 & $x$ & + & $20: 00$ & 23:00 \\
\hline $2016 / 07 / 04$ & & + & $18: 00$ & $22: 00$ \\
\hline $2016 / 07 / 05$ & & $x$ & & \\
\hline \multicolumn{5}{|l|}{$2016 / 07 / 06$} \\
\hline \multicolumn{5}{|l|}{$2016 / 07 / 07$} \\
\hline \multicolumn{5}{|l|}{$2016 / 07 / 08$} \\
\hline $2016 / 07 / 09$ & & + & $18: 00$ & $00: 00$ \\
\hline 2016/07/10 & & $x$ & & \\
\hline \multicolumn{5}{|l|}{$2016 / 07 / 11$} \\
\hline $2016 / 07 / 12$ & & + & 19:00 & 00:00 \\
\hline \multicolumn{5}{|l|}{$2016 / 07 / 13$} \\
\hline $2016 / 07 / 14$ & & $\times$ & & \\
\hline $2016 / 07 / 15$ & + & + & $20: 00$ & $01: 00$ \\
\hline $2016 / 07 / 16$ & + & + & 19:00 & 01:00 \\
\hline $2016 / 07 / 17$ & & $x$ & & \\
\hline $2016 / 07 / 18$ & & + & 18:00 & 00:00 \\
\hline
\end{tabular}

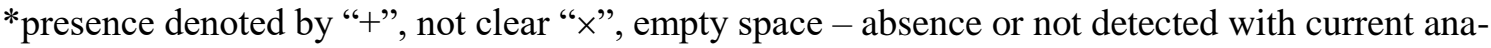
lysis settings

visible as brighter peaks in approximately same frequency interval $\Delta \mathrm{f}$ at a time, starting at $\sim$ 19:00 UT (E-W antenna), 16 July 2016, to 01:00 UT (both antennas), on 17 July 2016. The structures appear in the local evening and persist at night-time as observed previously at other locations. The SRS IAR frequency interval, $\Delta \mathrm{f}$, evolves in time as the ionosphere evolves and its parameters change in general as expected (e.g. Odzimek et al. 2006). The presence of SRS IAR in the analysed material, its onset and ending determined by visual inspection of calculated 
spectrograms, are notified in Table 1 . The approximate value of the $\Delta \mathrm{f}$ in this period is from a fraction of $\mathrm{Hz}$ to a maximum of about $1 \mathrm{~Hz}$.

\section{SUMMARY AND FUTURE WORK}

The spectral resonance structures of the ionospheric Alfven resonances have been detected for the first time in the magnetic signal of the ULF/ELF field measured near Suwałki in Poland. We conclude that:

- The preliminary analysis of ULF/ELF magnetic signal at Suwałki reveals presence of the SRS IAR features in agreement with similar events observed at other mid-latitude sites.

- In the summer period from mid-June to mid-July on about thirteen days the SRS IAR events have been observed during local night-time (in majority of cases in the signal from E-W antenna), and their frequency scale varied from a fraction to one $\mathrm{Hz}$.

- The magnetic ULF/ELF observations at Suwałki are suitable for the investigation of the IAR.

More detailed analysis of longer data series from the Suwałki site with regard to SRS IAR is planned for future work. The neighbourhood of simultaneous observations of ULF/ELF magnetic field at e.g. Hylaty, Poland (49.317 N, $22.933 \mathrm{E}, \mathrm{L} \cong 2.0)$ (Kulak et al. 1999, 2014), gives a unique possibility of investigating the aspects of IAR such as generation, propagation, and diagnosis of the ionosphere on a regional scale.

Preliminary analysis of data measured over the same period at high-latitude location in Hornsund, Svalbard (Neska et al. 2019), have not yet revealed pronounced SRS IAR events but we aim to monitor the spectral features of the data from both observation sites.

Acknowledgments. This work is supported by the Ministry of Science and Higher Education of Poland for the statutory activities of the Institute of Geophysics, Polish Academy of Sciences, grant No. 3841/E-41/S/2019.

\section{References}

Belyaev, P.P., S.V. Polyakov, V.O. Rapoport, and V.Yu. Trakhtengerts (1987), Discovery of the resonance spectrum structure of atmospheric electromagnetic noise background in the range of short-period geomagnetic pulsations, Doklady Akad. Nauk SSSR 297, 4, 840-843.

Belyaev, P.P., S.V. Polyakov, V.O. Rapoport, and V.Yu. Trakhtengerts (1989), Theory for the formation of resonance structure in the spectrum of atmospheric electromagnetic background noise in the range of short-period geomagnetic pulsations, Izvestiya Vysshikh Uchebnykh Zavedenii - Radiofizika 32, 7, 802-810.

Bösinger, T., C. Haldoupis, P.P. Belyaev, M.N. Yakunin, N.V. Semenova, A.G. Demekhov, and V. Angelopoulos (2002), Spectral properties of the ionospheric Alfvén resonator observed at a lowlatitude station $(\mathrm{L}=1.3)$, J. Geophys. Res. - Space 107, A10, 1281-1289, DOI: 10.1029/ 2001JA005076.

Fedorov, E., A.Yu. Schekotov, O.A. Molchanov, M. Hayakawa, V.V. Surkov, and V.A. Gladichev (2006), An energy source for the mid-latitude IAR: World thunderstorm centers, nearby discharges or neutral wind fluctuations?, Phys. Chem. Earth 31, 4-9, 462-468, DOI: 10.1016/ j.pce.2006.02.001. 
Kulak, A., K. Maslanka, A. Michalec, and S. Zieba (1999), Observations of Alfvén ionospheric resonances on the Earth's surface, Stud. Geophys. Geod. 43, 4, 399-406, DOI: 10.1023/ A:1023235219238.

Kulak, A., J. Kubisz, S. Klucjasz, A. Michalec, J. Mlynarczyk, Z. Nieckarz, M. Ostrowski, and S. Zieba (2014), Extremely low frequency electromagnetic field measurements at the Hylaty station and methodology of signal analysis, Radio Sci. 49, 6, 361-370, DOI: 10.1002/2014RS005400.

Lyons, R.G. (2000), Wprowadzenie do Cyfrowego Przetwarzania Sygnałów, Wydawnictwa Komunikacji i Łączności, Warszawa.

Lysak, R.L. (1991), Feedback instability of the ionospheric resonant cavity, J. Geophys. Res. - Space 96, A2, 1553-1568, DOI: 10.1029/90JA02154.

Molchanov, O.A., A.Yu. Schekotov, E.N. Fedorov, and M. Hayakawa (2004), Ionospheric Alfven resonance at middle latitudes: results of observations at Kamchatka, Phys. Chem. Earth 29, 4-9, 649-655, DOI: 10.1016/j.pce.2003.09.022.

Neska, M., and G. Sátori (2006), Obserwacje rezonansu Schumanna w Polskiej Stacji Polarnej na Spitsbergenie oraz Obserwatorium Geofizycznym w Belsku [Schumann resonance observation at Polish Polar Station at Spitsbergen and Geophysical Observatory in Belsk], Prz. Geof. 51, 3-4, 189-198.

Neska, M., P. Czubak, and J. Reda (2019), Schumann resonance monitoring in Hornsund (Spitsbergen) and Suwałki (Poland), Publs. Inst. Geophys. Pol. Acad. Sc. 425 (M-32), 39-43 (this issue).

Odzimek, A., A. Kulak, A. Michalec, and J. Kubisz (2006), An automatic method to determine the frequency scale of the ionospheric Alfvén resonator using data from Hylaty station, Poland, Ann. Geophys. 24, 8, 2151-2158, DOI: 10.5194/angeo-24-2151-2006.

Polyakov, S.V., and V.O. Rapoport (1981), Ionospheric Alfvén Resonator, Geomagn. Aeron. 21, 5, 816822.

Semenova, N.V., A.G. Yahnin, A.N. Vasilyev, S.P. Noskov, and A.I. Voronin (2005), First observations of the electromagnetic noise spectral resonance structures in the range of $0.1-4 \mathrm{~Hz}$ in the polar cap region (Barentsburg, Spitsbergen), Complex Investigations of Spitsbergen Nature 5, 120 131.

Yahnin, A.G., N.V. Semenova, A.A. Ostapenko, J. Kangas, J. Manninen, and T. Turunen (2003), Morphology of the spectral resonance structure of the electromagnetic background noise in the range of 0.1-4 Hz at L = 5.2, Ann. Geophys. 21, 5, 779-786, DOI: 10.5194/angeo-21-779-2003.

\title{
PIERWSZE OBSERWACJE WIDMOWYCH STRUKTUR REZONANSOWYCH JONOSFERYCZNEGO REZONANSU ALFVÉNA W POLU MAGNETYCZNYM ULF/ELF REJESTROWANYM W REJONIE SUWALK W POLSCE
}

\author{
Streszczenie
}

Analiza widmowa zmiennego pola magnetycznego w zakresie ultraniskich częstości ULF/ELF rejestrowanego na przełomie czerwca i lipca 2016 r. w Wigierskim Parku Narodowym - rejon Suwałk (54.012 N, 23.183 E, L = 2.47), wykazała istnienie rezonansowych struktur świadczących o działaniu jonosferycznego rezonansu Alfvéna (IAR), czyli detekcji tzw. rezonansowej struktury widmowej SRS IAR. Jonosferyczny rezonator Alfvéna (IAR) powstaje w obszarze F nocnej jonosfery w specyficznych warunkach zależnych od profilu masowej gęstości jonowej. Analiza 24-godzinnych spektrogramów w przedziale częstotliwości 
do $5 \mathrm{~Hz}$, opartych o uśrednione widmach mocy 5-minutowych serii czasowych, wykazała istnienie SRS IAR w trzynastu na trzydzieści rozważanych pomiarów dobowych. Cechy SRS IAR są zgodne z podobnymi przypadkami obserwowanymi w innych miejscach pomiarowych na średnich szerokościach geomagnetycznych. Parametr $\Delta \mathrm{f}$ SRS IAR w analizowanych przypadkach waha się w granicach od ułamka Hz do około $1 \mathrm{~Hz}$. Obserwacje IAR w Suwałkach stwarzają dodatkowe możliwości badawcze studiów nad zjawiskiem IAR i jonosferą, w szczególności generacją rezonansu, propagacją fal oraz diagnozą parametrów jonosferycznych, od których zależą cechy rezonansu. Opisane przypadki SRS IAR są pierwszymi obserwacjami tego zjawiska zarejestrowanymi w punkcie pomiarowym IGF PAN koło Suwałk w Polsce. 


\section{O N T E N T S}

Preface by Andrzej Kułak and Anna Odzimek

The Schumann Resonance and its applications -

Rezonans Schumanna i jego zastosowania

A. Kułak - Modern research on the Schumann Resonances -

Wspótczesne badania rezonansu Schumanna.

Z. Nieckarz, S. Zięba, and G. Michałek - Application of the Schumann Resonance spectral decomposition for the analysis of earth-ionosphere cavity attenuation Zastosowanie metody dekompozycji widma rezonansu Schumanna w celu analizy tlumienia wnęki Ziemia-jonosfera

K. Martyński, A. Kułak, and J. Młynarczyk - Studies on annual variations of African Storm Centre using the Schumann Resonance decomposition method Badanie rocznych zmian afrykańskiego centrum burzowego przy użyciu metody dekompozycji rezonansu Schumanna....

A. Kułak - Winfried Otto Schumann - An unfinished biography -

Winfried Otto Schumann - niedokończona biografia.

Observational systems, mathematical and numerical methods, modelling

Systemy pomiarowe, metody matematyczne i numeryczne oraz modelowanie

M. Neska, P. Czubak, J. Reda - Schumann resonance monitoring in Hornsund

(Spitsbergen) and Suwałki (Poland) -

Obserwacje rezonansu Schumanna w Hornsundzie (Spitsbergen) i w Suwatkach

(Polska)....

J. Mlynarczyk, A. Kulak, S. Klucjasz, J. Kubisz, A. Michalec - First results from a new broadband ELF measurement system -

Pierwsze wyniki z nowego szerokopasmowego systemu pomiarowego ELF.

J. Koperski - A few glances on fractional calculus from the geophysical-ELF point of view Kilka spojrzeń na rachunek frakcjalny z punktu widzenia badań geofizycznych $E L F$

ELF, LF and HF remote sensing

Teledetekcja w pasmie ELF, LF i HF

M. Gołkowski, A. Kulak, J. Mlynarczyk, J. Kubisz - ELF remote sensing of the lower ionosphere using group velocity of electromagnetic radiation from atmospheric lightning discharges -

Teledetekcja najniższej warstwy jonosfery przy pomocy prędkości grupowej promieniowania elektromagnetycznego ELF od wytadowań atmosferycznych

J. Kozakiewicz - ELF exploration of MarsBadanie Marsa za pomoca fal ELF. 
A. Neska, S. Oryński, K. Nowożyński - Schumann Resonance Monitoring (ELF)

Records as Remote Reference Data for Magnetotelluric Soundings -

Obserwacje ELF jako dane referencyjne w magnetotelluryce

M. Pozoga, B. Matyjasiak, H. Rothkaehl, R. Wronowski, Ł. Tomasik - ELF signatures in low and high radio frequency signals -

Sygnatury ELF w obserwacjach sygnałów radiowych na falach dtugich i krótkich ........ 71

G. Góral - SuperDARN radars - introduction -

Radary SuperDARN - wprowadzenie.

Thunderstorms, lightning discharges and ULF/ELF/LF radiation

Układy burzowe, wyładowania atmosferyczne i promieniowanie w pasmie

$\mathrm{ULF} / \mathrm{ELF} / \mathrm{LF}$

K. Martynski, A. Kulak, J. Mlynarczyk, J. Blecki, R. Wronowski, R. Iwanski Connections between electromagnetic signals generated by Mesoscale Convective Systems, observed by an ELF ground station and DEMETER satellite Powiazania pomiędzy sygnałami elektromagnetycznymi wygenerowanymi przez Mezoskalowe Uktady Konwekcyjne, obserwowane przez naziemna stację ELF oraz satelite DEMETER.

P. Barański - Electric structure of multiple Cloud-to-Ground flashes obtained from the Local Lightning Detection Network recordings during thunderstorm in the Warsaw region on 25 May 2018 -

Struktura elektryczna doziemnych wyładowań wielokrotnych na podstawie ich detekcji $w$ sieci pomiarowej LSDWA w rejonie Warszawy podczas burzy 25-05$2018 \mathrm{r}$

A. Odzimek, M. Neska - First detection of spectral resonance structures of the ionospheric Alfvén resonance in ULF/ELF magnetic field recorded at Suwałki, Poland -

Pierwsze obserwacje widmowych struktur rezonansowych jonosferycznego rezonansu Alfvéna w polu magnetycznym $U L F / E L F$ rejestrowanym $w$ rejonie Suwatk w Polsce. 
"Publications of the Institute of Geophysics, Polish Academy of Sciences: Geophysical Data Bases, Processing and Instrumentation" appears in the following series:
A - Physics of the Earth's Interior
B - Seismology
C-Geomagnetism
D - Physics of the Atmosphere
E - Hydrology (formerly Water Resources)
P - Polar Research
M - Miscellanea

Every volume has two numbers: the first one is the consecutive number of the journal and the second one (in brackets) is the current number in the series. 

